MARCO TÚLLIO BRAZÃO SILVA

Expressão gênica funcional das metalotioneínas no carcinoma epidermoide bucal

São Paulo 
MARCO TÚLLIO BRAZÃO SILVA

\title{
Expressão gênica funcional das metalotioneínas no carcinoma epidermoide bucal
}

\author{
Versão Corrigida
}

Tese apresentada à Faculdade de Odontologia da Universidade de São Paulo, para obter o título de Doutor, pelo Programa de Pós-Graduação em Odontologia.

Área de Concentração: Estomatologia e patologia básica e aplicada.

Orientadora: Profa. Dra. Suzana Cantanhede Orsini Machado de Sousa

São Paulo 
Autorizo a reprodução e divulgação total ou parcial deste trabalho, por qualquer meio convencional ou eletrônico, para fins de estudo e pesquisa, desde que citada a fonte.

Catalogação da Publicação Serviço de Documentação Odontológica Faculdade de Odontologia da Universidade de São Paulo

Silva, Marco Túllio Brazão.

Expressão gênica funcional das metalotioneínas no carcinoma epidermóide bucal / Marco Túllio Brazão Silva; orientador Suzana Cantanhede Orsini Machado de Sousa. -- São Paulo, 2014.

148 p. : il. : fig. : tab. ; $30 \mathrm{~cm}$.

Tese (Doutorado) -- Programa de Pós-Graduação em Odontologia. Área de Concentração: Estomatologia e Patologia Básica e Aplicada. -- Faculdade de Odontologia da Universidade de São Paulo.

Versão corrigida.

1. Neoplasias Bucais. 2. Carcinoma de Células Escamosas. 3. Metaloproteinases. 4. Metástase Neoplásicas. I. Sousa, Suzana Cantanhede Orsini Machado de. II. Título. 
Brazão-Silva MT. Expressão gênica funcional das metalotioneínas no carcinoma epidermoide bucal. Tese apresentada à Faculdade de Odontologia da Universidade de São Paulo para obtenção do título de Doutor em Odontologia.

Aprovado em: / /2014

\section{Banca Examinadora}

$\operatorname{Prof}(\mathrm{a}) . \operatorname{Dr}(\mathrm{a})$.

Instituição:

Julgamento:

$\operatorname{Prof}(\mathrm{a}) . \operatorname{Dr}(\mathrm{a})$.

Instituição:

Julgamento:

Prof(a). Dr(a).

Instituição: Julgamento:

$\operatorname{Prof}(\mathrm{a}) . \operatorname{Dr}(\mathrm{a})$.

Instituição: Julgamento:

Prof(a). Dr(a).

Instituição: Julgamento: 
Dedico este trabalho a toda minha família, e às pessoas que me incentivaram positivamente nesta caminhada, especialmente minha mãe Marizete Caldeira Brazão da Silva e ao meu pai João Batista da Silva Júnior. 


\title{
AGRADECIMENTOS
}

\begin{abstract}
A Deus,
em primeiro lugar, pelo vigor e saúde de cada dia, e, agora, pela alegria deste trabalho concretizado, acompanhado de oportunidades valiosíssimas de contato e crescimento profissional. Agradeço a Deus ainda pelos colaboradores desta pesquisa, que foram como anjos ao compartilharem comigo conhecimento e energia para avanço da mesma, e pelos amigos que pude fazer nesta caminhada. Para algumas destas pessoas, faço agradecimento individual durante este capítulo.
\end{abstract}

\section{Aos meus pais,}

por acreditarem nesta busca por solidez profissional e acadêmica... este doutorado marca o início de nossas vidas em residências distintas... porém, deixou ainda mais claro que posso sempre contar com vocês... e que este amor é incondicional.

\section{À Universidade de São Paulo,}

que me recebendo enquanto aluno, deixa para sempre em meu histórico e currículo o registro desta fase crucial de minha formação acadêmica sob sua estrutura e corpo de pesquisadores internacionalmente respeitados. Aqui pude conhecer profissionais brilhantes e de referência na arte de diagnóstico bucal, especialmente Profa. Suzana C. O. Machado de Sousa, Prof. Décio dos Santos Pinto Júnior, Prof. Fábio Daumas Nunes, Profa. Marília Trierveiler Martins, com os quais tive oportunidade de conviver nas rotinas de diagnóstico histopatológico e nas disciplinas oferecidas dentro do curso.

\section{Ao Laboratório de Patologia Molecular,}

que me ofereceu a estrutura ideal para execução dos procedimentos de biologia molecular que foram fundamentais para o resultado deste trabalho. Neste sentido, agradeço em especial ao Prof. Fábio Daumas Nunes, que sempre me recebeu com respeito e abriu as portas para o uso do laboratório. Neste ambiente foi possível conviver com pessoas com as quais troquei conhecimento científico além de boas 
conversas cotidianas, como Lilia Araújo (aluna de Pós-doutorado), Agnelo Alves e Nadhia Costa (pós-graduação da Uninove).

\section{Ao INCA,}

que representa o centro nacional de maior tradição e volume de diagnóstico e tratamento de câncer. Graças a esta grandeza, e oportunidade de pesquisa dada aos grupos de pesquisa externos, pudemos encontrar as amostras ideais para o presente trabalho. $\mathrm{O}$ cuidado de registros nos prontuários, que é peculiar, a proximidade e perfeccionismo nos cuidados com os pacientes, e, ainda, o cuidado no armazenamento de materiais biológicos, fazem da instituição fonte riquíssima de dados para pesquisas que vislumbram o bem da humanidade. Especial agradecimento à Profa. Dra. Ana Lúcia Amaral Eisemberg, que a todo momento se prontificou a defender e apoiar nossa pesquisa, sempre com extrema ética e interesse em qualidade e resultados dignos. Agradeço também ao Prof. Dr. Fernando Luís Dias, que observando a seriedade do grupo de pesquisa envolvido neste trabalho, se disponibilizou a encabeçar nossa pesquisa no INCA como pesquisador responsável dentro da instituição.

\section{À equipe do Arquivo Médico do INCA,}

principalmente ao Sr. Ildálio, ao Claudionor e ao Lula, que sempre nos receberam com carinho, sempre muito compreensivos com a nossa condição de pesquisadores externos, facilitando o acesso mais ágil aos arquivos para conseguirmos finalizar as consultas durante os períodos dispendiosos de viagem ao Rio de Janeiro.

\section{À equipe do Banco Nacional de Tumores do INCA,}

que trabalhando em um padrão exemplar de banco de tumores, nos abriu as portas imediatamente, com apoio principal de Dr. Gustavo Stefanoff. Agradecimento especial aos técnicos Fernando e Helem, sempre muito gentis e amigáveis, propiciando dias de trabalho com mais alegria.

\section{Ao Prof. Dr. Adriano Mota Loyola,}

que representa para mim um grande mestre, e hoje tenho como amigo. Sempre me inspira persistência, ética, dignidade e humildade. Passamos com sabedoria e humildade muitos momentos de dificuldade na busca das amostras de nossas 
pesquisas. Hoje temos uma tese porque tivemos muita paciência e "sangue nas veias". Obrigado por caminhar junto nesta vitória, e obrigado por propiciar a maior parte dos insumos desta pesquisa.

\section{À minha orientadora,}

\section{Profa. Dra. Suzana C. O. Machado de Sousa,}

que sem dúvida é uma das melhores patologistas bucais de nosso país. Mas antes disto, é uma pessoa idônea e sensata. Quando não soube me ajudar, me direcionou a alguém e me deu liberdade nas decisões. Aliás, nosso trabalho construiu-se sobre uma base composta por confiança, liberdade e respeito. A confiança de acreditar que eu faria o que fosse possível para defender este projeto. A liberdade foi dada a partir da confiança, e assim foram cumpridas todas as etapas, tais como a busca de amostras no INCA do Rio de Janeiro, cumprimento de créditos, participação no Programa de Aperfeiçoamento de Ensino, participação na rotina de exames histopatológicos, execução dos experimentos. O respeito foi fundamental ao apoiarme nas minhas decisões, como a de exercer minha primeira experiência como docente em instituição privada. Muitos foram os momentos que pude aprender com seus modos, generosos, delicados.

\section{À Luciana Castro,}

que até então gerente responsável pelo BNT-INCA. Foi muito prestativa ao tomar conhecimento dos objetivos de meu trabalho e compartilhar de sua expertise em biologia molecular para que os primeiros passos laboratoriais da pesquisa fossem concretizados. Sempre se disponibilizou mesmo nos trabalhos de bancada, aumentando muito a produtividade nos momentos que estive no BNT-INCA. Obrigado pela paciência e pelos ensinamentos.

\section{À Dra. Maria Fernanda Setubal,}

que se dedicou ao propósito do presente trabalho até mesmo como orientadora. Acreditando no trabalho, e sendo extremamente prestativa, deu todo o suporte para o planejamento e execução de toda a parte experimental realizada no LPM.

Obrigado pela parceria, e até mesmo pela amizade. A qualidade deste trabalho tem seu toque. 


\section{Ao meu irmão, Marllos Leandro Brazão Silva}

obrigado pela amizade e incentivo. Meu esforço também é resultado da vontade de mostrar que somos capazes.

\section{À Wellem Ribeiro Silva,}

que entrou em minha vida de repente e foi fundamental nesta caminhada. Com seu amor me deu tranquilidade e motivação. Obrigado por ter participado intensamente, me dando coragem, me incentivando a lutar e a erguer a cabeça naqueles momentos onde as dificuldades pareciam insuperáveis. Tenho certeza que também vai comemorar esta vitória, e que pode comemorá-la. Obrigado meu amor!

\section{Aos amigos presentes,}

Ao amigo Bruno Rodrigues Reis, que inicialmente seria um colega para dividir despesas e aos poucos se tornou um amigo confidente, companheiro de academia, pizzarias, bares, missas, e demais programações economicamente possíveis durante esta etapa. Também me proporcionou oportunidade de conhecer alunos muito legais do departamento de materiais dentários, Lucas Pabis, Fernando Maeda, Renata Medeiros, Karin A Fukushima, Tamara Tedesco. Agradeço ainda a todos os amigos do departamento de Patologia Bucal, dentre eles o Kauê, amigo hilário, companheiro de muitos momentos agradáveis, levo para a vida. Douglas Magno, pessoa simples, humilde, extremamente prestativa, e de uma capacidade notória. Difícil seria não se tornar seu amigo. Também levo com muito carinho pelo companheirismo as amigas Karin de Sá, Luciene Miguita, Paula Prieto, Rita Barcessat, Michela Lima, Tathyane Teshima, Daniella M Antunes, Ana Maria Hoyos. Obrigado pelas caronas, convívios em reuniões, cafés, almoços no bandejão. Não posso esquecer da amizade com as secretárias Nair, Zilda e Néia. Obrigado por serem tão gentis e facilitarem nossas vidas. Deus Ihes pague. Obrigado ao amigo Victor Matsubara e seu pai, Paulo Matsubara, que me receberam com todo carinho e gratuitamente em seus lares no Rio de Janeiro e São Paulo. Agradeço a Deus a oportunidade de conhecê-los. Infelizmente não é possível listar todas as pessoas especiais que estiveram comigo. Então, de maneira injusta, finalizo agradecendo:

\section{Á todas as pessoas que estiveram ao meu lado nesta caminhada, Muito obrigado!}

Venci! E, de alguma forma, Vencemos! 
"Deus não levantou Golias para matar Davi. Deus levantou Golias para honrar Davi. Seu gigante irá mudar a história da sua vida." (autor desconhecido) 


\section{RESUMO}

Brazão-Silva MT. Expressão gênica funcional das metalotioneínas no carcinoma epidermoide bucal [tese]. São Paulo: Universidade de São Paulo, Faculdade de Odontologia; 2014. Versão corrigida.

O carcinoma epidermoide bucal (CEB) é uma malignidade epitelial que causa grande mortalidade. As metalotioneínas (MTs) são proteínas envolvidas na homeostasia de metais e eventos oxidativos. Estudos de expressão proteica a apontaram como marcadora de prognóstico e comportamento metastático para o CEB. A análise da expressão gênica das mesmas tem auxiliado no entendimento deste papel para outros tumores, mas ainda não foi estudada no CEB. O objetivo deste trabalho foi avaliar o perfil de expressão gênica das MTs no CEB e em fragmentos de mucosa oral (MOC), além de sua relação com dados clínicopatológicos, comportamento metastático e prognóstico. Para tal, foram utilizadas amostras armazenadas a $-80^{\circ} \mathrm{C}$ no Banco Nacional de Tumores do Instituto Nacional de Câncer, constando de 35 casos de CEB de língua e/ou assoalho bucal e $35 \mathrm{MOC}$. Todos os fragmentos foram submetidos ao qRT-PCR com uso de TaqMan $^{\circledR}$ para os genes: MT1A, MT1B, MT1E, MT1F, MT1G, MT1H, MT1X, MT2A, MT3 e MT4. A expressão dos genes $M T 1 B$ e $M T 1 H$ foi raramente detectada. Houve queda significativa de expressão dos genes MT1A, MT1X, MT3 e MT4 e aumento significativo de expressão de $M T 1 F$ no $C E B$ com relação à $M O C$. Casos de baixa expressão de $M T 1 G$ tiveram pior prognóstico. A alta expressão de $M T 1 X$ indicou casos não metastáticos e a alta expressão de MT3 indicou casos metastáticos. Em suma, foi demonstrado pela primeira vez o perfil gênico das MTs no CEB, indicando que a mesma pode fornecer informações sobre o prognóstico e comportamento metastático do CEB.

Palavras-chave: Metalotioneínas. qRT-PCR. Carcinoma epidermoide bucal. Prognóstico. Metaástase. 


\begin{abstract}
Brazão-Silva MT. Functional gene expression of metallothioneins in oral squamous cell carcinoma [thesis]. São Paulo: Universidade de São Paulo, Faculdade de Odontologia; 2014. Versão corrigida.
\end{abstract}

The oral squamous cell carcinoma (OSCC) is a malignancy that causes high mortality. Metallothioneins (MTs) are proteins involved in metal homeostasis and antioxidant events. Studies regarding its protein expression indicated its potential as marker of prognosis and metastatic behavior, also for OSCC. The analysis of its specific gene expression can clarify its importance in these aspects and no study has been done for OSCC. The aim of this work was to evaluate the profile of gene expression of MTs in OSCC and samples of non-neoplastic oral mucosa (OM), evaluating its relationship with clinic-pathologic characteristic, metastatic behavior and prognosis for OSCC. For this, tissue samples archived at $-80^{\circ} \mathrm{C}$ at the National Bank of Tumors of the Brazilian National Institute of Cancer were collected, in a total of 35 cases of OSCC and 35 fragments of OM. All tissues were submitted to qRTPCR with TaqMan ${ }^{\circledR}$ for the genes: MT1A, MT1B, MT1E, MT1F, MT1G, MT1H, MT1X, MT2A, MT3 e MT4, besides the constitutive gene GAPDH. Expressions of MT1B and $M T 1 H$ were rarely detected. There was significant loss of expression for MT1A, MT1X, MT3 and MT4 and gain of expression for MT1F comparing OSCC with OM. Cases with down-regulation of $M T 1 G$ had the worst prognosis. Up-regulation of MT1X indicated non-metastatic cases whereas up-regulation of MT3 indicated metastatic ones. In conclusion, this study shows for the first time the profile of gene expression of MTs on OSCC indicating distinctive patterns of regulation for each, and giving associations with prognosis and metastatic behavior of cases.

Keywords: Methallotionein. qRT-PCR. Oral squamous cell carcinoma. Prognosis. Metastasis. 


\section{LISTA DE FIGURAS}

Figura 2.1 - Marcadores biológicos testados para o carcinoma epidermoide bucal e sua relevância como fator de prognóstico. A) Relação da classe dos marcadores levantados de estudos publicados no período de 19972002 [adaptado de Schliephake 2003]. B) Relação e classe dos marcadores utilizados em imunohistoquímica nos estudos publicados no período de 2005 a 2009 para o CEB revisão [adaptado de Oliveira e Ribeiro-Silva 2011]. 34

Figura 2.2 - Estrutura da MT mamífera saturada por Zinco (Zn). A) Sequência de aminoácidos que compõem a estrutura primária das diferentes isoformas proteicas da MT. As iniciais sombreadas de rosa representam os resíduos altamente conservados das MTs, presentes em todas as isoformas. Os aminoácidos divergentes da estrutura primária da MT1 estão sublinhados em vermelho, e as sequencias adicionais estão sublinhadas em verde [Adaptado de Moleirinho et al. 2011]. B) Esquema representativo do arranjo da MT formando os domínios $\alpha$ e $\beta$ em um exemplo saturado com Zn. Os radicais tiol (S) formam ligações diretas aos átomos de $\mathrm{Zn}$ [Adaptado de Fischer and Davie 1998].

Figura 2.3 - Ilustração da família gênica da Metalotioneína no cromossomo $16 q 13$. Há um gene único para MT2 (em azul claro), MT3 (em rosa) e MT4 (em verde), enquanto 8 genes funcionais codificam a MT1 (em azul escuro). Em azul escuro, com margens tracejadas observam-se os genes não funcionais ou pseudogenes de MT1. A direção de transcrição está indicada pela flexa. Os números descritos representam o tamanho das regiões dos genes em Kb [adaptado de Moleirinho et al. 2011]...........41

Figura 2.4 - Modelo representativo das interações potencialmente ativas na regulação de expressão das Metalotioneínas [modelo adaptativo das interações representadas por Coyle et al. 2002 e Davis and Cousins 2000].

Figura 4.1 - A) Corte histológico em criostato dos fragmentos armazenados no BNT. B) Coloração com azul de toluidina a $1 \%$ para visualização da lâmina espelho do caso.

82

Figura 4.2 - Painél de lâminas espelho elaboradas a partir dos fragmentos de CEB e EOC coletados. Nas áreas tracejadas observa-se uma simulação de áreas a serem eliminadas com o bisturi na macrodissecção. A) fragmento de EOC com extensa área de tecido conjuntivo eliminada. B) 
fragmento de EOC com área de tecido conjuntivo e músculo eliminadas na macrodissecção. C) fragmento de CEB com área de tecido conjuntivo e glândula salivar menor eliminadas na macrodissecção. D) Fragmento de CEB com grande quantidade de tumor, sem necessidade de macrodisseç̧ão (> $70 \%$ de tumor)..............................83

Figura 4.3 - Demonstração de protocolo de higienização do triturador de tecidos (Omni $\mu \mathrm{H}$, Micro Homogenizer) após uso em cada um dos fragmentos utilizados no estudo. 84

Figura 4.4 - Avaliação de integridade do RNA das amostras por corrida em gel de agarose $2 \%$ para visualização das subunidades $18 \mathrm{~S}$ e $28 \mathrm{~S}$ do RNA ribossômico. As amostras 3, 4 e 7 foram consideradas inadequadas e excluídas do estudo. .86

Figura 4.5 - Configuração recomendada para qPCR segundo o manual da Applied Biosystems. 88

Figura 4.6 - Curva padrão obtida a para o gene MT2A partir da diluição de amostras de SCC-9 em 5 logs.

Figura 5.1 -'Gráficos de análise de sobrevida segundo parâmetros clínicopatológicos potencialmente relacionados com prognóstico. A) Gráfico dissociando a amostra segundo os parâmetros de T do sistema TNM. B) Gráfico dissociando a amostra segundo o comportamento metastático do CEB (excluídos casos Nx e casos Mx). C) Gráfico dissociando a amostra segundo o evento "extravasamento capsular linfonodal" (EC) em casos com metástase nodal com descrição de EC $(\mathrm{N}+\mathrm{EC})$, casos com metástase nodal sem $\mathrm{EC}(\mathrm{N}-\mathrm{EC})$ e casos não metastáticos. .96

Figura 5.2 Expressão dos genes das metalotioneínas em carcinoma epidermoide bucal e na mucosa oral correspondente aos casos. Diferenças significativas são ressaltadas com asterisco ( * ). A mediana de expressão para mucosa oral correspondente está ressaltada na cor vermelha. A mesma foi utilizada para dividir os tumores em alta e baixa expressão para as análises com relação aos dados clínico-patológicos.

Figura 5.3 - Expressão gênica das metalotioneínas segundo o comportamento metastático do carcinoma epidermoide bucal. Diferenças significativas estão marcadas com asterisco (*). A mediana de expressão obtida para 
a mucosa oral correspondente aos casos (MOC) está ressaltada em vermelho, pois divide os tumores em alta e baixa expressão. ...........104

Figura 5.4 - Análise de sobrevida entre casos de carcinoma epidermoide de alta expressão e casos de baixa expressão para o gene MT1G. .............107 


\section{LISTA DE TABELAS}

Tabela 2.1 - Distribuição proporcional dos dez tipos de câncer mais incidentes estimados para 2012 por sexo, exceto pele não melanoma (FONTE:

INCA).

Tabela 2.2 - Características gerais adotadas no sistema TNM utilizado para estadiamento do carcinoma epidermoide bucal (versão adaptada de publicação do INCA, disponível em http://www.inca.gov.br/tratamento/tnm/). .........................................26

Tabela 2.3 - Sumário do papel da família das metalotioneínas enquanto marcadoras de agressividade e progressão para tumores de órgãos diversos. .......58

Tabela 2.4 - Sumário de resultados dos estudos que avaliaram a expressão de Metalotioneína em carcinoma epidermoide bucal 62

Tabela 4.1 - Relação das isoformas da Metalotioneína e características dos ensaios desenhados pela Applied Biosystems para sua identificação por meio de qPCR. 88

Tabela 5.1 - Dados clínicopatológicos referentes aos 35 casos de carcinomas epidermóides bucais incluídos no presente estudo

Tabela 5.3 - Relação entre isoformas de Metalotioneína e a proporção de casos onde foi identificada sua expressão dentre os 40 ciclos de RT-qPCR executados. 97

Tabela 5.4 - Valores de mediana, mínino e máximo de expressão dos genes das metalotioneínas normalizada com o gene constitutivo GAPDH por meio de RT-qPCRnos casos de carcinoma epidermoide bucal e amostras da mucosa oral correspondente. 
Tabela 5.5 - Relação de casos de carcinoma epidermoide bucal de alta e baixa expressão, determinados a partir da mediana de expressão obtida na mucosa oral correspondente aos casos. 100

Tabela 5.6 - Relação de valores de "p" obtidos após comparação de grupos separados por critérios clínico-patológicos com relação à expressão dos genes das metalotioneínas. 101

Tabela 5.7 - Relação de casos de alta e baixa expressão gênica das metalotioneínas segundo dados clínico-patológicos 102

Tabela 5.8 - Expressão das isoformas de Metalotioneína segundo o comportamento metastático do Carcinoma Epidermoide Bucal.

Tabela 5.9 - Expressão gênica da MT em tumores metastáticos e não metastáticos, divididos segundo a mediana de expressão das isoformas em grupos de tumores de maior expressão e tumores de menor expressão..............105

Tabela 5.10 -Expressão gênica da MT em tumores metastáticos e não metastáticos, divididos segundo a mediana de expressão das isoformas em grupos de tumores de maior expressão e tumores de menor expressão 106

Tabela 5.11 - Relação dos valores de "p" obtidos após análise de Mantel-Cox com relação à xpressão gênica das metalotioneínas e a sobrevida dos pacientes, comparando casos de carcinoma epidermoide de alta expressão com os casos de baixa expressão. ...................................107 


\section{SUMÁRIO}

1 INTRODUÇÃO

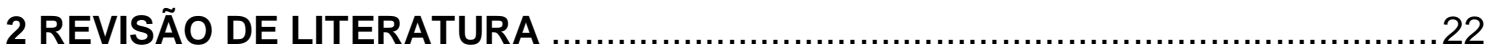

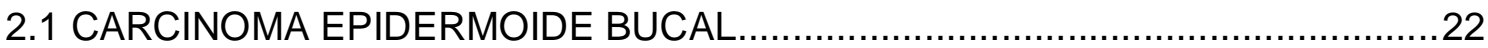

2.1.1 Características gerais do carcinoma epidermoide bucal .......................22

2.1.2 Fatores clínico-patológicos e moleculares relacionados ao

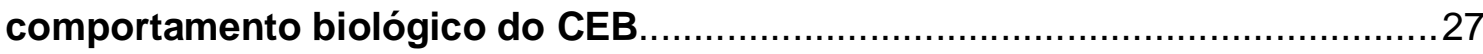

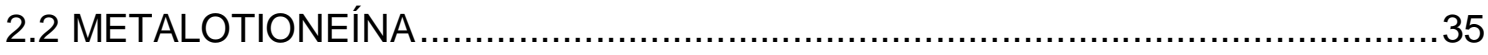

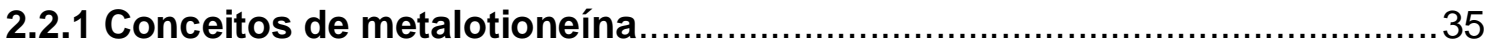

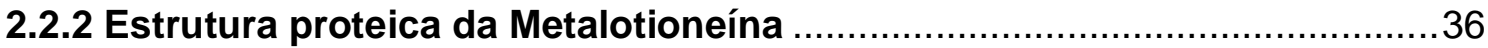

2.2.3 Regulação gênica da Metalotioneína ..................................................... 40

2.2.4 Aspectos funcionais da Metalotioneína .............................................. 46

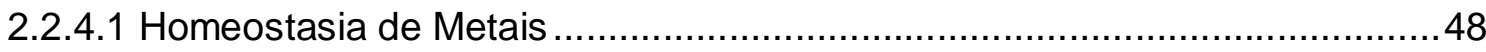

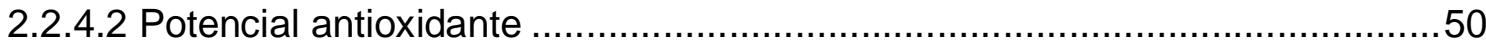

2.2.5 Atuação da Metalotioneína no processo neoplásico …….......................52

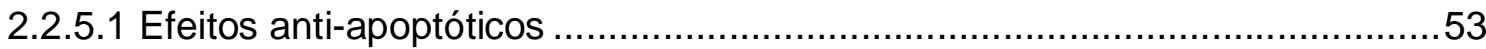

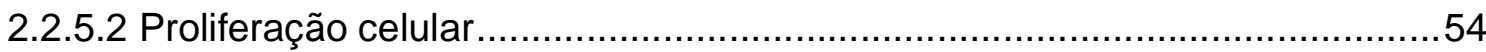

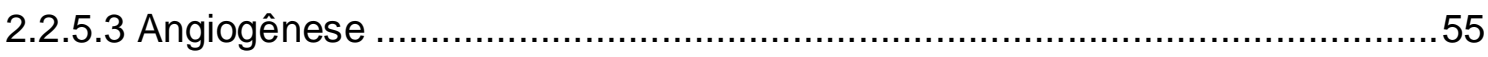

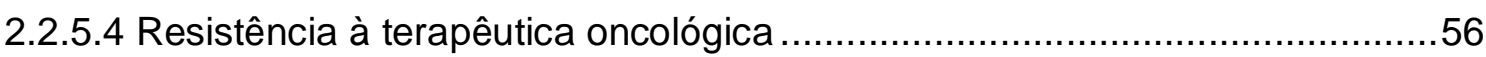

2.2.6 Expressão da MT em neoplasias e tecidos não neoplásicos

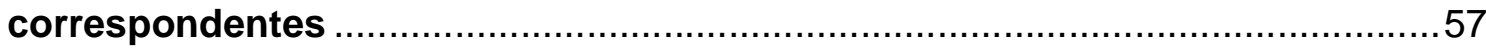

2.2.7 Metalotioneína em mucosa oral e carcinoma epidermoide bucal..............59

2.2.8 Expressão da metalotioneína em outros tecidos ..................................... 62

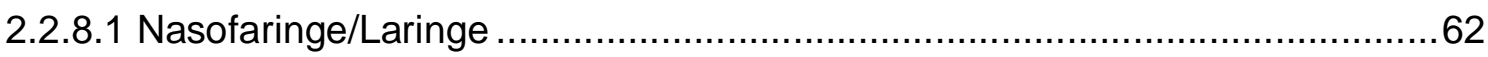

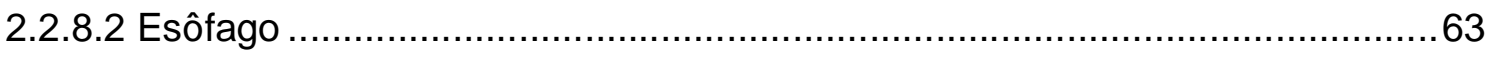

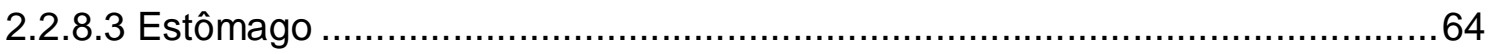

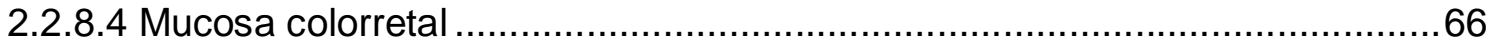

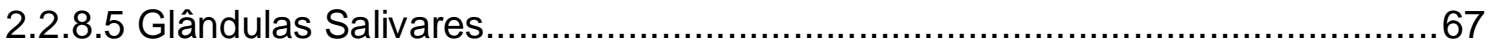

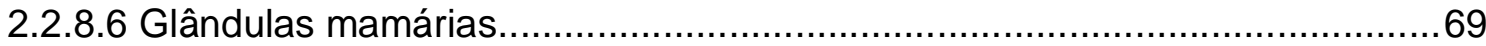

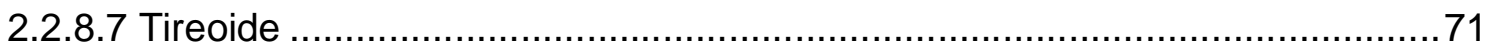

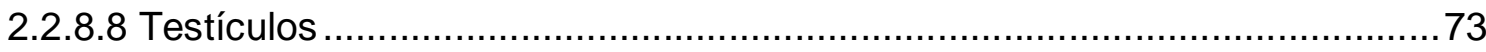

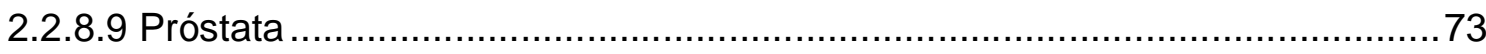

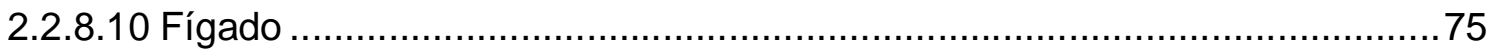




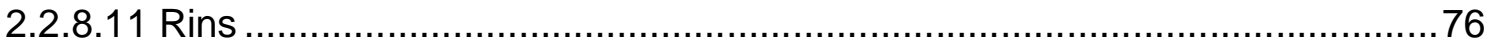

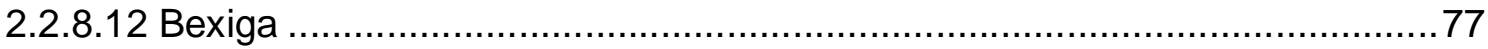

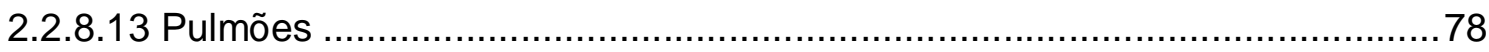

3. PROPOSIÇÃO

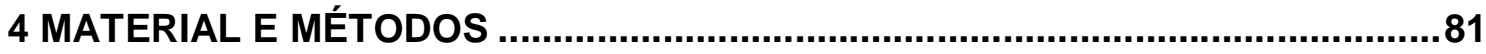

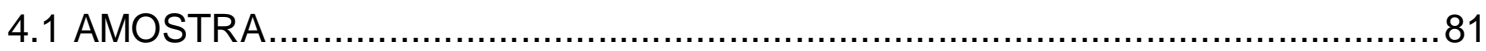

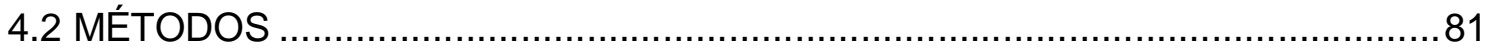

4.2.1 Avaliação dos fragmentos teciduais e macrodissecção ............................. 81

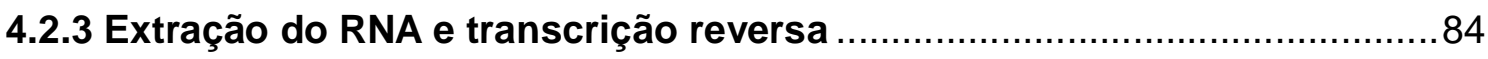

4.2.4 Reação em cadeia da polimerase (PCR) ……................................... 87

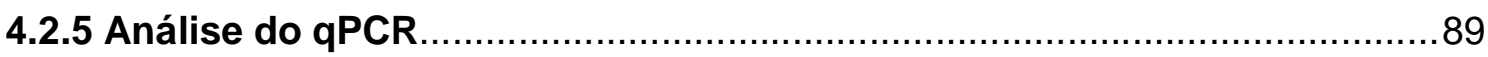

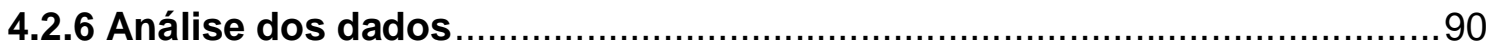

5. RESULTADOS

5.1 DADOS CLÍNICO-PATOLÓGICOS ............................................................... 92

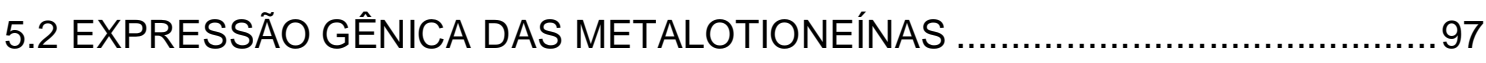

5.2.1 Quantificação da expressão das Metalotioneínas...................................97

5.2.2 Expressão de Metalotioneína em Carcinoma Epidermoide Bucal segundo parâmetros clinico-patológicos .........................................................100

5.2.3 Expressão gênica das metalotioneínas em carcinoma epidermoide bucal segundo o comportamento metastático tumoral ...................................103

5.2.4 Expressão gênica das Metalotioneína em Carcinoma Epidermoide

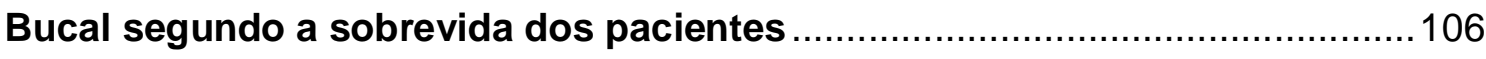

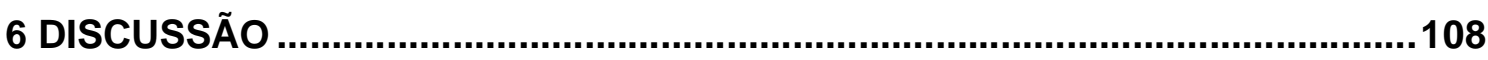

7 CONCLUSÕES

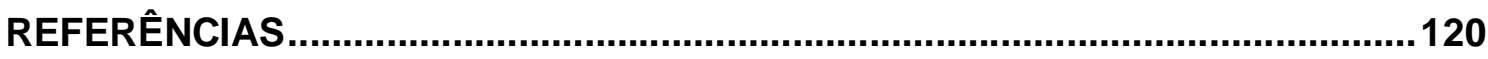

APÊNDICE

ANEXOS 


\section{INTRODUÇÃO}

O carcinoma epidermoide bucal é frequentemente descrito dentre as dez neoplasias malignas mais comuns do homem. Os locais de maior ocorrência intrabucal são língua e assoalho bucal, porém uma distinção dentre estas topografias pode ser dificultada em tumores amplos. O uso crônico do tabaco é o fator de risco mais comum para seu desenvolvimento, com uma minoria de casos ocorrendo em não tabagistas. Apesar dos avanços de técnicas cirúrgicas e melhorias em tratamento radio e quimioterápico, não se obteve grandes mudanças nos índices de sobrevida nas últimas décadas. A capacidade metastática dos tumores representa o melhor marcador de prognóstico dos casos. Diversos estudos se ocupam na busca de marcadores biológicos do CEB que possam auxiliar na identificação precoce de agressividade tumoral e auxiliar na determinação um de tratamento mais específico. Marcadores de ciclo celular e proliferação, supressão tumoral e apoptose, angiogênese e adesão celular e degradação de matriz tem sido estudados, dentre eles as metalotioneínas.

As Metalotioneínas (MT) são proteínas ricas em cisteína associadas à homeostasia de metais e eventos oxidativos. Atua em diversos processos celulares, incluindo o funcionamento de enzimas e hormônios envolvidos na multiplicação e desenvolvimento celular. Existem quatro isoformas das MTs, que por sua vez são reguladas por pelo menos 10 genes distintos situados no cromossomo 16. Diversos trabalhos associam o aumento de expressão proteica das MTs a um comportamento mais agressivo de tumores de vários órgãos, incluindo comportamento metastático e queda de sobrevida. Alguns trabalhos já demonstraram este papel também para o carcinoma epidermoide bucal. Existem evidências de que a regulação gênica das isoformas das MTs está alterada em diversos processos neoplásicos e pode fornecer informações mais específicas sobre o papel de cada isoforma da MT no desenvolvimento e progressão tumoral, incluindo o comportamento metastático. O presente trabalho representa o primeiro estudo que faz esta avaliação no carcinoma epidermoide bucal, buscando interpretar se a expressão dos genes das MTs está associada a alguma das características clínico-patológicas do CEB que possa estar associada ao prognóstico, e ainda avaliar sua relação com a sobrevida dos pacientes. 


\section{REVISÃO DE LITERATURA}

\subsection{CARCINOMA EPIDERMOIDE BUCAL}

\subsubsection{Características gerais do carcinoma epidermoide bucal}

Câncer de boca é uma denominação que inclui os cânceres de lábio e o de cavidade oral propriamente dita (mucosa bucal, gengivas, palato duro, língua oral e assoalho da boca). Mais de $90 \%$ dos cânceres de boca são diagnosticados como carcinomas epidermoides. O carcinoma epidermoide bucal (CEB) é definido pela Organização Mundial de Saúde como uma neoplasia epitelial invasiva com variados graus de diferenciação e propensão para metástases linfonodais precoces e disseminadas, ocorrendo predominantemente em adultos usuários de tabaco e álcool que estão na $5^{\text {a }}$ e $6^{\text {a }}$ décadas de vida (Johnson et al., 2005). Segundo o Instituto Nacional de Câncer (INCA), no Brasil, as estimativas de câncer oral para o ano de 2014 também serão válidas para o ano de 2015. Em homens, os tipos mais incidentes serão os cânceres de próstata, pulmão, cólon e reto, estômago e cavidade oral; e, nas mulheres, os de mama, cólon e reto, colo do útero, pulmão e glândula tireoide (Tabela 1). O câncer de boca em mulheres ocupa a décimasegunda posição. A estimativa aponta a ocorrência de 11.280 novos casos de câncer de boca em homens e 4.010 em mulheres, um aumento de casos em homens e leve redução em mulheres comparando-se com a estimativa do ano anterior (2012-2013), que apontava 9.990 casos em homens e 4.180 em mulheres. Sem considerar os tumores da pele não melanoma, o câncer de boca está entre a quarta e sexta posições de tumores mais frequentes para pessoas do sexo masculino no Brasil e entre a nona e décima-segunda posição para pessoas do sexo feminino, com maiores incidências nas regiões Nordeste e Sudeste para ambos os sexos. Finalmente, no Brasil, o câncer de boca representa para 2014 3,7\% dos casos em homens e 1,4\% em mulheres (Estimativa 2014: incidência de câncer no 
Brasil. 2014). Mundialmente, segundo os últimos dados chancelados pela Organização Mundial de Saúde (OMS) por meio do projeto Globocan, em sua estimativa 2012 o câncer de lábio e cavidade bucal ocupa a décima primeira posição para o sexo masculino e a décima sétima para o sexo feminino, correspondendo a correspondendo a 2,7\% e 1,5\% dos cânceres, respectivamente (GLOBOCAN 2012: estimated cancer incidence, mortality and prevalence worldwide in 2012).

Os pacientes com lesões iniciais são frequentemente assintomáticos, enfatizando a importância do autoexame das mucosas orais, principalmente para os pacientes com hábitos de tabagismo e etilismo, e do cuidadoso exame de mucosa oral pelo profissional cirurgião dentista. O reconhecimento de lesões conhecidas "potencialmente malignas", principalmente das leucoplasias e eritroplasias, possui valor fundamental para a redução da mortalidade por CEB, visto que aproximadamente $10 \%$ destas lesões avançarão para uma transformação em CEB (Neville et al., 2004). O sinal clínico característico do CEB inclui uma úlcera com bordos elevados e endurecidos. Sintomas como dor (por vezes referida para o ouvido), odor fétido, dificuldades de movimentação da língua, de abertura bucal, dentre outros, são mais restritos às lesões avançadas (Johnson et al., 2005).

Tabela 2.1 - Distribuição proporcional dos dez tipos de câncer mais incidentes estimados para 2014 por sexo, exceto pele não melanoma (FONTE: INCA, 2014)

\begin{tabular}{|c|c|c|c|c|c|c|c|}
\hline Localizaçâo primária & casos & $\%$ & & & Localizaçāo primária & casos & $\%$ \\
\hline Próstata & 68.800 & $22,8 \%$ & Homens & Mulheres & Mama Feminina & 57.120 & $20.8 \%$ \\
\hline Traqueia, Brônquio e Pulmāo & 16.400 & $5,4 \%$ & & & Cólon e Reto & 17.530 & $6,4 \%$ \\
\hline Cólon e Reto & 15.070 & $5,0 \%$ & & & Colo do Útero & 15.590 & $5,7 \%$ \\
\hline Estômago & 12.870 & $4,3 \%$ & & & Traqueia, Brônquio e Pulmâo & 10.930 & $4,0 \%$ \\
\hline Cavidade Oral & 11.280 & $3,7 \%$ & & & Gländula Tireoide & 8.050 & $2,9 \%$ \\
\hline Esôfago & 8.010 & $2,6 \%$ & & & Estômago & 7.520 & $2,7 \%$ \\
\hline Laringe & 6.870 & $2,3 \%$ & & & Corpo do Útero & 5.900 & $2,2 \%$ \\
\hline Bexiga & 6.750 & $2,2 \%$ & & & Ovário & 5.680 & $2,1 \%$ \\
\hline Leucemias & 5.050 & $1,7 \%$ & & & Linfoma näo Hodgkin & 4.850 & $1,8 \%$ \\
\hline Sistema Neryoso Central & 4.960 & $1,6 \%$ & & & Leucemias & 4.320 & $1,6 \%$ \\
\hline
\end{tabular}

*Números arredondados para 10 ou múltiplos de 10.

Com relação à localização das lesões no interior da cavidade oral, a língua tem sido colocada como a localização mais comum, principalmente em sua borda lateral. Entretanto, analisando lesões pequenas e assintomáticas, o assoalho bucal parece ser o local de maior acometimento, seguindo então para porção ventro-lateral de 
língua e complexo de palato mole. Assim, supõe-se que alguns tumores linguais possam ter iniciado em assoalho, com crescimento predominante para a porção lingual. De qualquer forma, assoalho e língua são as duas regiões de maior incidência do CEB e devem ser avaliadas cuidadosamente em pacientes tabagistas e etilistas de longa data (Johnson et al., 2005). Em uma amostra de mais de 26.000 pacientes na Flórida com CEB verificou-se que tumores linguais foram os mais frequentes, representando quase $35 \%$ da amostra, seguido de tumores em assoalho, que somaram aproximadamente $20 \%$. Outros casos incluíram palato $(\sim 13 \%)$, lábio ( 15\%). As demais localizações anatômicas somaram aproximadamente $20 \%$ dos casos. O tabagismo é o fator de risco mais comum, seja associado ao fumo, seja mascado, como é frequente em regiões da índia. O fator de risco para câncer de lábio é essencialmente a exposição solar (Kolker et al., 2007).

No geral, a cura tem sido observada para aproximadamente $50 \%$ dos casos de carcinomas epidermoides de cabeça e pescoço. Aproximadamente $33 \%$ dos pacientes exibem lesão em estágio inicial (estágios I e II) e tem uma sobrevida de aproximadamente $80 \%$ em cinco anos, outros $57 \%$ são diagnosticados com doença local avançada (estágios III e IVB) e tem uma sobrevida de pouco mais de $50 \%$, e, por fim, 35\% dos pacientes são diagnosticados com doença metastática e (estágio IVc) tem uma sobrevida de aproximadamente 30\% em cinco anos (Siegel et al., 2013). Um pior prognóstico é reservado para pacientes com doença recorrente e/ou metastática depois de instituído tratamento, sendo observada uma sobrevida global média de 3 a 4 meses, com menos de $5 \%$ dos pacientes vivos em um ano (León et al., 2005).

O sistema de estadiamento tumoral mais frequente e universalmente aceito é o sistema TNM da Union Internationale Contre le Cancer (UICC) e do American Committee on Cancer (AJCC). Neste sistema são consideradas características anatômicas do quadro clínico em relação ao CEB, como a extensão do tumor primário $(\mathrm{T})$, a presença e extensão de metástase linfonodal $(\mathrm{N})$, e a presença ou ausência de metástase à distância (M). A tabela 2.2 demonstra os critérios utilizados neste sistema para CEB. Algumas combinações entre as subclassificações para os critérios $\mathrm{T}, \mathrm{N}$, e $\mathrm{M}$ foram elaboradas a partir da observação de comportamentos clínicos semelhantes, determinando quatro estádios para o $\mathrm{CEB}$, onde o quarto estágio, em tese, representa a pior combinação de TNM com relação ao prognóstico. Quando o estadiamento é feito antes do tratamento, é referido como 
TNM clínico, ou cTNM. Quando esta classificação é feita após exame histopatológico do tumor e/ou dos linfonodos regionais do material removido cirurgicamente, o sistema é referido como TNM patológico, ou pTNM., sendo principalmente importante na seleção da terapia adjuvante pós-operatória e na estimativa do prognóstico (Johnson et al., 2005).

O sistema TNM apresenta notáveis imperfeições, sendo que existem pacientes com CEB em estágio I que morrem rapidamente, e, inversamente, pacientes com estágio IV que possuem sobrevida prolongada. As imperfeições do sistema e seu uso como referência para a seleção do tratamento e estabelecimento de prognóstico pode levar a tratamentos exagerados para alguns casos e tratamentos insuficientes para outros. Corrobora com este pensamento o fato de que muitos pacientes que passam por esvaziamento cervical não apresentam metástase linfonodal confirmada histologicamente. De fato, a presença ou ausência de metástase linfonodal é o ponto mais importante na determinação da terapia cirúrgica e do prognóstico. Entretanto, os exames para sua detecção não são precisos ou utilizados uniformemente para classificar os casos. Por exemplo, um exame puramente clínico pode não ser suficiente para identificar uma metástase linfonodal como uma ressonância magnética. O exame histopatológico dos linfonodos, que seria o padrão ouro para diagnóstico de metástase linfonodal, também possui falhas, que variam desde a capacidade cirúrgica de remoção adequada de todos os linfonodos envolvidos, até a capacidade do patologista de identificá-los durante a manipulação do espécime (Takes et al., 2010).

Com relação ao aspecto histológico do CEB, três graus de diferenciação têm sido tradicionalmente categorizados. Os tumores bem diferenciados são aqueles que mantêm características muito semelhantes ao epitélio oral normal. Tumores moderadamente diferenciados são aqueles que contêm pleomorfismo nuclear e maior atividade mitótica, usualmente exibindo uma queratinização menor. Por último, tumores pobremente diferenciados são aqueles em que as células imaturas predominam, com numerosas mitoses, por vezes atípicas, e a queratinização mínima (Cardesa et al., 2005). Quando e sempre que possível, também é realizada uma avaliação da fronte de invasão tumoral, ou seja, da porção tumoral mais profunda que faz interface com o estroma aparentemente livre. Quando nesta fronte invasiva observa-se um padrão de crescimento expansivo, caracterizado por projeções tumorais largas, com margens bem definidas, um melhor prognóstico 
geralmente é esperado. Por outro lado, uma fronte de invasão exibindo um padrão infiltrativo, caracterizado por ilhotas pequenas e irregulares, com pouca coesão das células tumorais, caracteriza um tumor mais agressivo (Cardesa et al., 2005).

Tabela 2.2 - Características gerais adotadas no sistema TNM utilizado para estadiamento do carcinoma epidermoide bucal (versão adaptada de publicação do INCA, disponível em http://www.inca.gov.br/tratamento/tnm/)

\section{TNM - Classificação Clínica}

\section{T - Tumor Primário}

TX O tumor primário não pode ser avaliado.

T0 Não há evidência de tumor primário.

Tis Carcinoma in situ

T1, T2, T3, T4 Tamanho crescente e/ou extensão local do tumor primário

\section{N - Linfonodos Regionais}

NX Os linfonodos regionais não podem ser avaliados.

No Ausência de metástase em linfonodos regionais.

N1, N2, N3 Comprometimento crescente dos linfonodos regionais

Nota: A extensão direta do tumor primário para o linfonodo é classificada como metástase linfonodal. Metástase em qualquer linfonodo que não seja regional é classificada como metástase à distância.

\section{M - Metástase à Distância}

MX A presença de metástase à distância não pode ser avaliada.

M0 Ausência de metástase à distância

M1 Metástase à distância

\section{Estadiamento:}

Estádio I: TINO

Estádio II: T2NO

Estádio III: T3N0, T3N1, T2N1, T1N1

Estádio IV: todos os outros.

O tratamento empregado para o CEB, na prática, tem sido elaborado a partir do estadiamento clínico dos casos. Basicamente, para casos iniciais, a radioterapia (RT) ou a cirurgia são utilizadas com objetivo de cura. Já para casos mais avançados, uma combinação de terapia local (cirurgia ou radioterapia) com quimioterapia sistêmica é amplamente utilizada. Segundo o protocolo do INCA, 
casos de lesões linguais classificadas como T1N0M0 serão tratados cirurgicamente com margem de $1,0 \mathrm{~cm}$ de tecido aparentemente sadio, além de esvaziamento cervical supra-omo-hióideo em virtude do alto risco de metástases ocultas. A RT será utilizada em metástases linfonodais múltiplas após esvaziamento cervical radical. A quimioterapia associada à radioterapia é empregada nos casos mais avançados, quando a cirurgia não é possível (http://www.inca.gov.br/conteudo_view.asp?id=324). Em um estudo, por exemplo, a cirurgia foi preconizada para casos de CEB menores que cinco $\mathrm{cm}$, a cirurgia associada a esvaziamento cervical e braquiterapia intersticial para casos maiores que cinco $\mathrm{cm}$. Neste centro, localizado na Espanha, a radioterapia é utilizada para casos metastáticos e a radioterapia associada à quimioterapia para casos onde há acometimento linfonodal com extravasamento capsular (Guinot et al., 2010). A identificação e excisão do linfonodo sentinela, ou seja, do primeiro linfonodo que drena a região acometida pelo tumor, tem sido estudada em vários centros de oncologia como uma alternativa para evitar esvaziamentos cervicais desnecessários e prevenir metástases ocultas para pacientes classificados como NO (Farias et al., 2009).

Finalmente, observa-se que muitos desafios ainda precisam ser vencidos para que se obtenham formas de tratamento menos agressivas e que proporcionem melhores resultados em longo prazo. Assim, os estudos sobre marcadores biológicos do CEB são fundamentais para o avanço desta ciência que pode trazer muitos benefícios para os pacientes.

\subsubsection{Fatores clínico-patológicos e moleculares relacionados ao comportamento biológico do CEB}

Os aspectos clínico-patológicos do CEB, principalmente aqueles incluídos no sistema TNM, continuam sendo a melhor referência para discussão do comportamento biológico deste tumor, além de representarem a ferramenta padrão para determinação de tratamento e prognóstico. Com relação aos fatores biomoleculares, a presente revisão tem meramente o objetivo de contextualizar a 
gama de estudos que se esforçam na busca de novas possibilidades para determinação de prognóstico, bem como possibilidades de alvos moleculares para terapias alvo-específicas. Ressalta-se, entretanto, que é praticamente impossível formatar uma revisão que possa contemplar com fidelidade a amplitude de marcadores e possibilidades que já foram testados com esta finalidade com relação ao CEB.

A idade dos pacientes parece ter algum significado neste sentido, onde usualmente um prognóstico reservado é dado para pacientes mais idosos. Não há um parâmetro nos estudos, sendo que o valor de cut-off significativo para alguns é 45 anos de idade e para outros é 60 (O-charoenrat et al., 2003; Süslü et al., 2013). Aparentemente, não há diferenças claras de prognóstico entre pacientes do sexo masculino e feminino, embora alguns autores relatem menor sobrevida em mulheres, que muitas vezes pode ser atribuída a um atraso no diagnóstico pela demora na procura de cuidados médicos e menor aceitação ao tratamento (Lo et al., 2003; Massano et al., 2006; O-charoenrat et al., 2003). Com relação ao hábito de tabagismo e etilismo, também existem informações contraditórias na literatura, porém alguns autores relatam pior sobrevida para os tabagistas, além de maior incidência de segundos primários, o que pode causar maior morbidade e assim impactar na sobrevida dos pacientes (Carvalho et al., 2004; Johnson et al., 2005; Ribeiro et al., 2000). O hábito de mascar o fumo com betel ou na forma de "quid", que é uma mistura de mistura de noz de areca com tabaco e cal apagada é comum em algumas comunidades asiáticas e está especialmente correlacionado com prognóstico pior (Lo et al., 2003). As condições socioeconômicas dos pacientes também podem resultar em pior prognóstico visto que o conhecimento e a procura por cuidados médicos podem ser algumas vezes negligenciados ou de difícil acesso (Leite; Koifman, 1998). Outro ponto que também deve ser considerado é a presença de comorbidades tais como doença cardíaca congestiva, arritmia, doenças pulmonares, renais, dentre outras, que podem comprometer as terapêuticas propostas ou podem agravar-se como resultado do estresse gerado pelo CEB (Piccirillo et al., 2002; Ribeiro et al., 2000).

O estadiamento baseado no TNM tem sido intensamente atribuído como um sistema carregado de imperfeições. Apesar disto, é o sistema que tem maior potencial prognóstico e continua sendo o sistema mais aceito e mais utilizado mundialmente. Guerra e colaboradores relatam que a sobrevida para pacientes em 
estágios iniciais é de $82 \%$ em cinco anos, enquanto que para casos avançados a sobrevida é de $49 \%$ (31). Lo e colaboradores descreveram uma sobrevida de $75 \%$, $65,5 \%, 49 \%$, e $30 \%$ para os estágios I, II, III e IV, respectivamente (Lo et al., 2003). Nguyen e colaboradores (2000) encontraram sobrevida de 60\% para pacientes em estágio I e 32\% para pacientes em estágio IV, com recidivas, doença persistente ou segundos primários. Avaliando somente lesões de envolvimento lingual, Suslu e colaboradores (2013) observaram sobrevida de aproximadamente $20 \%$ em cinco anos para tumores T4, enquanto que tumores T1, T2 e T3 possuem sobrevida de aproximadamente $60 \%, 56 \%$ e $40 \%$, respectivamente. A avaliação da espessura tumoral também tem demonstrado seu valor no que diz respeito ao risco de metástase linfonodal. Em um trabalho observa-se maior risco para tumores com mais de $5 \mathrm{~mm}$ de espessura e em outro para tumores com mais de $8 \mathrm{~mm}$ de espessura (O-charoenrat et al., 2003; Süslü et al., 2013).

A disseminação para linfonodos locais tem sido implicada como um dos fatores clínico-patológicos mais importantes na determinação do prognóstico (Johnson et al., 2005; Süslü et al., 2013). A metástase linfonodal oculta ocorre em cerca de 40\% dos casos e as cadeias ganglionares sob maior risco são aquelas dos níveis I, II e III (O-charoenrat et al., 2003). O extravasamento capsular metastático é definido como uma extensão metastática que rompe os limites do linfonodo envolvido. Quando este evento acontece, uma queda de sobrevida entre $29 \%$ a $60 \%$ pode ser observada (Woolgar et al., 2003). Segundo a OMS, o mecanismo de disseminação metastática regional é quase sempre por embolismo tumoral (Johnson et al., 2005). Estudos recentes mostram que as células do CEB possuem potencial de estimular uma formação de nova rede linfática a partir da expressão de fatores de crescimento como o fator vascular de crescimento endotelial C (VEGF-C), que é responsável pelo estímulo linfangiogênico ao receptor três do fator (VEGFR-3). Foi demonstrado que a inibição de VEGF-C reduz o potencial de motilidade e invasão de células de CEB in vitro e a avaliação de sua expressão pode discriminar casos de CEB com metástase regional de casos com metástase ocorrendo após o tratamento (Bock et al., 2008; Warburton et al., 2007). Outros trabalhos demonstram o potencial do uso do fator de crescimento de hepatócito (c-Met) para identificação da linfangiogênese, demonstrando inclusive correlação com VEGF-C e com o acometimento metastático regional (Lim et al., 2012; Zhao et al., 2011). Outro marcador que tem sido exaustivamente avaliado em diversas neoplasias e no CEB é a podoplanina, um 
marcador de alta afinidade para vasos linfáticos e que pode discriminar casos de CEB com metástase linfonodal (Huber et al., 2011; Miyahara et al., 2007). Outros trabalhos demonstram valor preferencial para estabelecimento do prognóstico a partir da determinação da densidade microvascular determinada pela avaliação da rede vascular com o auxílio de marcadores como o CD105, VEGF-A e VEGF-B, demonstrando associação com acometimento linfonodal e queda de sobrevida (Sousa et al., 2012; Shintani et al., 2004). Desta forma, as moléculas envolvidas na formação de rede linfática e/ou vascular tumoral são promissoras como marcadoras de comportamento metastático, sobrevida, e até mesmo para estabelecimento de novas terapias alvo. Porém, mais estudos ainda são necessários para avaliar os marcadores e suas relações em amostras maiores, pois avaliando os fatores isoladamente, observa-se sensibilidade e especificidade baixas para o uso geral dos marcadores com este propósito (Santos Almeida et al., 2013; Sousa et al., 2012). A terapia atual mais aplicada para o tratamento de metástase regional inclui 0 esvaziamento cervical e/ou radioterapia.

A avaliação de componentes intratumorais do CEB tem fornecido dados importantes que podem direcionar o manejo clínico do paciente. O grau histológico é o parâmetro histológico mais utilizado no diagnóstico, porém com valor limitado para prognóstico, visto que há comportamento biológico muito heterogêneo dentro de casos classificados dentro de um mesmo padrão de diferenciação (Leite; Koifman, 1998; O-charoenrat et al., 2003). A presença de invasão perineural nos cortes histológicos pode ser indicador de tumores com propensão a metástase e curso clínico agressivo (Brandwein-Gensler et al., 2005; Rahima et al., 2004). Outras características, como a presença de margem comprometida, ausência de infiltrado inflamatório marginal, presença de invasão perineural e quantificação das formações de pérolas córneas, também demonstram certa importância para o prognóstico em certos estudos (Brandwein-Gensler et al., 2005; Matos et al., 2012). Porém, os resultados não são reproduzidos em todos os estudos, de maneira que é necessário criar parâmetros histológicos mais precisos e de complexidade acessível.

Marcadores moleculares são potencialmente úteis para a identificação do risco de surgimento de neoplasia, para o diagnóstico precoce de malignidade, para determinação do prognóstico, para predizer eficiência terapêutica, para manter sobrevida após a remoção do tumor primário, e para eliminação do tumor. Basicamente, os marcadores mais estudados para o CEB podem ser divididos em: 
relacionados ao crescimento tumoral (proliferação e aceleração do ciclo celular); supressão de tumor e resposta antitumoral (resposta imune e apoptose); angiogênese e linfangiogênese; invasão tumoral e metástase (moléculas de adesão e degradação da matriz).

Dentre os muitos oncogênes mais estudados, destaca-se o receptor do fator de crescimento epidérmico (EGFR), que foi exaustivamente estudado até 0 reconhecimento dos efeitos positivos da droga que bloqueia sua função. A droga conhecida como cetuximab hoje pode ser utilizada como alvo terapêutico para o CEB autorizado pela FDA (Watters et al., 2011). Outros marcadores que codificam receptores de fatores de crescimento comumente alterados no CEB incluem o ErbB2 (HER-2 ou neu), ErbB-3 (HER-3) e ErbB-4 (HER-4). Dentre os fatores de transcrição envolvidos na progressão do CEB, destacam-se o c-Myc e AP-1 (um dímero composto por c-Jun e c-Fos), que demonstram grande relevância na progressão tumoral, sendo implicado em crescimento tumoral, angiogênese e metástase (Mees et al., 2009). Marcadores de proliferação celular também fornecem informações importantes sobre a progressão tumoral, como o antígeno nuclear de células em proliferação (PCNA), que aumenta principalmente na fase $S$ do ciclo celular, e o anticorpo monoclonal Ki-67, que evidencia uma proteína presente em todas as fases do ciclo celular exceto G0 (Liu et al., 2003; Myoung et al., 2006). Outros marcadores de ciclo celular são as proteínas do complexo ciclina/cdk, que é complexo inexistente na fase G0 do ciclo celular e fundamental para que a célula se multiplique, pois clivam resíduos de tirosina e outras moléculas, como por exemplo, fosforilando a Rb para liberar fatores de transcrição (Harada et al., 2006; Thomson et al., 2006). Neste sentido, a ciclina D1 tem sido identificada como marcadora de progressão e comportamento metastático do CEB (Huang et al., 2012).

$O$ desequilíbrio de mecanismos de indução de apoptose contribui substancialmente para a imortalidade das células do CEB e a progressão tumoral. Dentre os marcadores de controle de apoptose, destaca-se a p53, que é um dos marcadores moleculares mais estudados em CEB. A p53 que age como um fator de transcrição que controla o ciclo celular seja paralisando o ciclo em G1 a partir da ativação do gene $p 21$, seja acionando a apoptose através de ligações a genes que codificam co-fatores como Bax e GADD45. Este último liga-se ao PCNA, um co-fator para ciclina $D$ e assim inibe a transição de $G 1$ para $S$ do ciclo celular. $A$ p53 também ativa o gene que codifica a proteína três ligante de IGF (IGF-BPtrês), que bloqueia o 
fator de crescimento dependente de insulina e então promove apoptose. A produção de p53 é controlada pela indução por feedback negativo por meio de MDM-2, uma proteína que se liga à p53 causando sua degradação (Scully et al., 2000). A perda de função de p53 causa defeitos no reparo do ADN celular e prejuízo no processo de apoptose, causando subsequente aumento de instabilidade genética que pode levar ao acúmulo de mutações (Chari et al., 2009). Uma alta expressão de p53 tem sido frequentemente associada a um prognóstico ruim para o CEB e a associação com outros fatores como ciclina D1 e EGFR associa-se com queda acentuada de sobrevida (Oliveira et al., 2007; Shiraki et al., 2005).

Moléculas de adesão celular também podem fornecer informações importantes sobre a progressão tumoral, principalmente com relação ao potencial invasivo e metastático tumoral. A família das metaloproteinases de matriz (MMPs) são proteínas normalmente expressas em tumores invasivos e no estroma adjacente (Vicente et al., 2005). Trata-se de uma família de mais de vinte endopeptidases associadas a zinco (zn) que são capazes de degradar todos os componentes da matriz extracelular. As principais MMPs estudadas em progressão tumoral de CEB são as MMP-2, MMP-7, MMP-9, e MMP-14 . As proteínas da família das caderinas, particularmente a E-caderina e a P-caderina, também representam importantes proteínas que estão alteradas no CEB, conferindo maior motilidade celular e propensão a metástase (Oliveira; Ribeiro-Silva, 2011).

Uma revisão de literatura realizada por Schliephake (2003) sobre os estudos publicados dentre o período de 1997 a 2002 revela maior potencial de marcadores de atividade supressora de tumor e/ou atividade antitumoral na determinação do prognóstico do CEB (Figura 2.1-A) (Schliephake, 2003). Oliveira e Ribeiro-Silva (2011) fizeram revisão semelhante sobre os utilizados em estudos com imunohistoquímica em CEB, publicados no período de 2005 a 2009. A partir da análise das tabelas deste estudo foi possível construir a figura 2.1-B, o que permite corroborar com a tendência observada no estudo anterior, porém também chama a atenção para marcadores de adesão celular e degradação de matriz. Um total de 22 marcadores biológicos foram contabilizados nesta revisão (Oliveira; Ribeiro-Silva, 2011).

Baseando-se nesta breve revisão sobre fatores clínico-patológicos e moleculares com potencial preditivo de comportamento biológico do CEB, é possível observar que muitas moléculas têm sido investigadas com o intuito de evoluir este tópico. A 
terapêutica existente atualmente ainda é muito agressiva e gera alta morbidade aos pacientes. As ferramentas utilizadas para planejamento de estratégia terapêutica continuam restritas aos dados coletados pelo sistema TNM, com pouca evolução no que diz respeito aos aspectos histopatológicos e biomoleculares do CEB. Dentre as limitações dos marcadores, destaca-se a dificuldade de reprodutibilidade de resultados. Muitos estudos fornecem evidências do potencial preditivo e prognóstico dado pela avaliação das metalotioneínas em tumores de outros órgãos, com algumas evidências que apontam este potencial se estendendo para o CEB. Estudos com neoplasias de outros órgãos demonstram que a avaliação da expressão gênica destas proteínas contribui substancialmente na elucidação das alterações que ocorrem durante a progressão neoplásica, principalmente pelo fato de poder distinguir com exatidão as isoformas que participam do processo neoplásico, o que não é possível pelas técnicas de avaliação e quantificação proteica. A expressão gênica das MTs ainda não foi estudada para o CEB e pode ser passo importante para ratificar ou desmistificar o papel das metalotioneínas como marcadora de comportamento biológico do CEB. 
A)
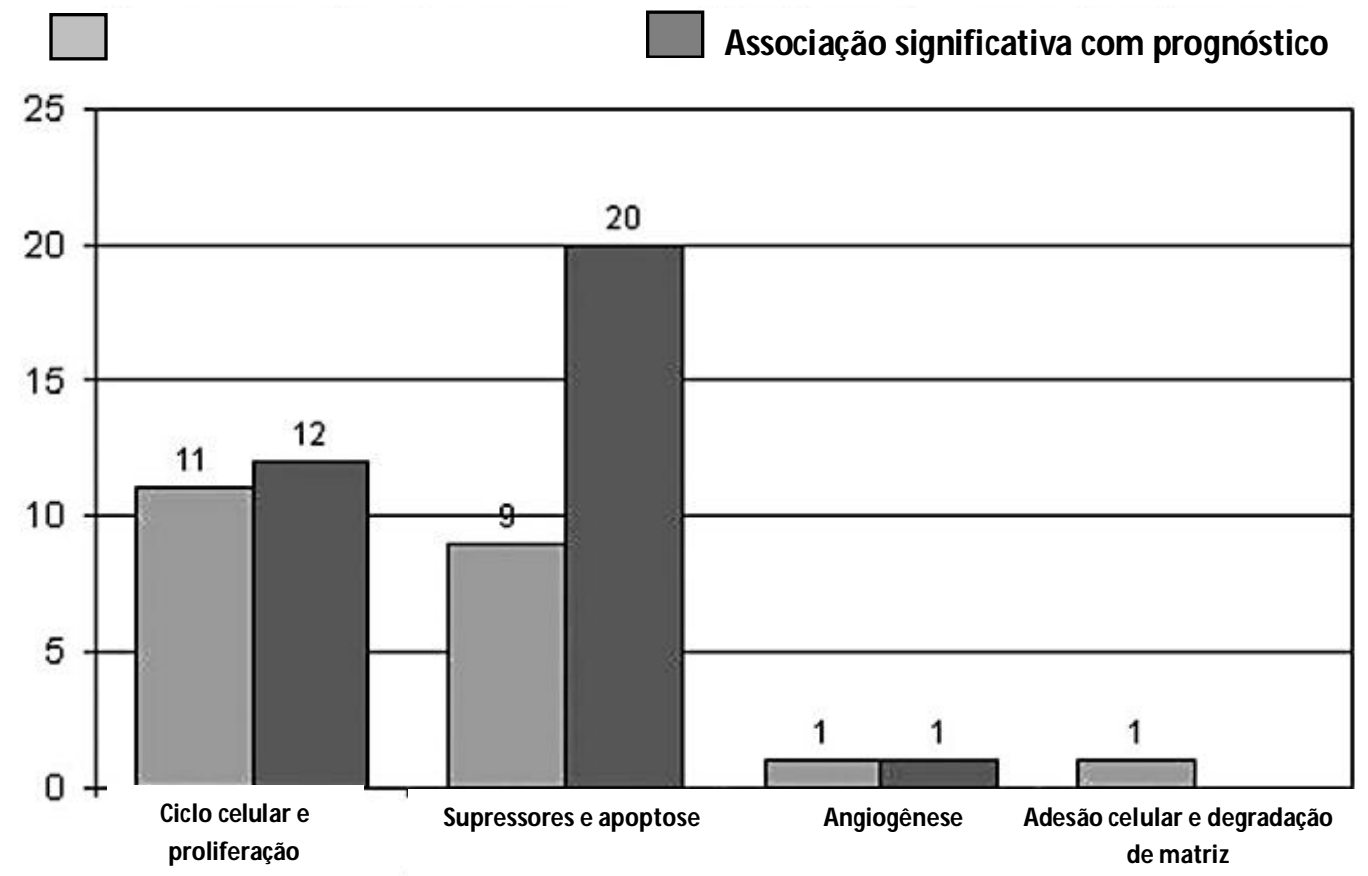

B)

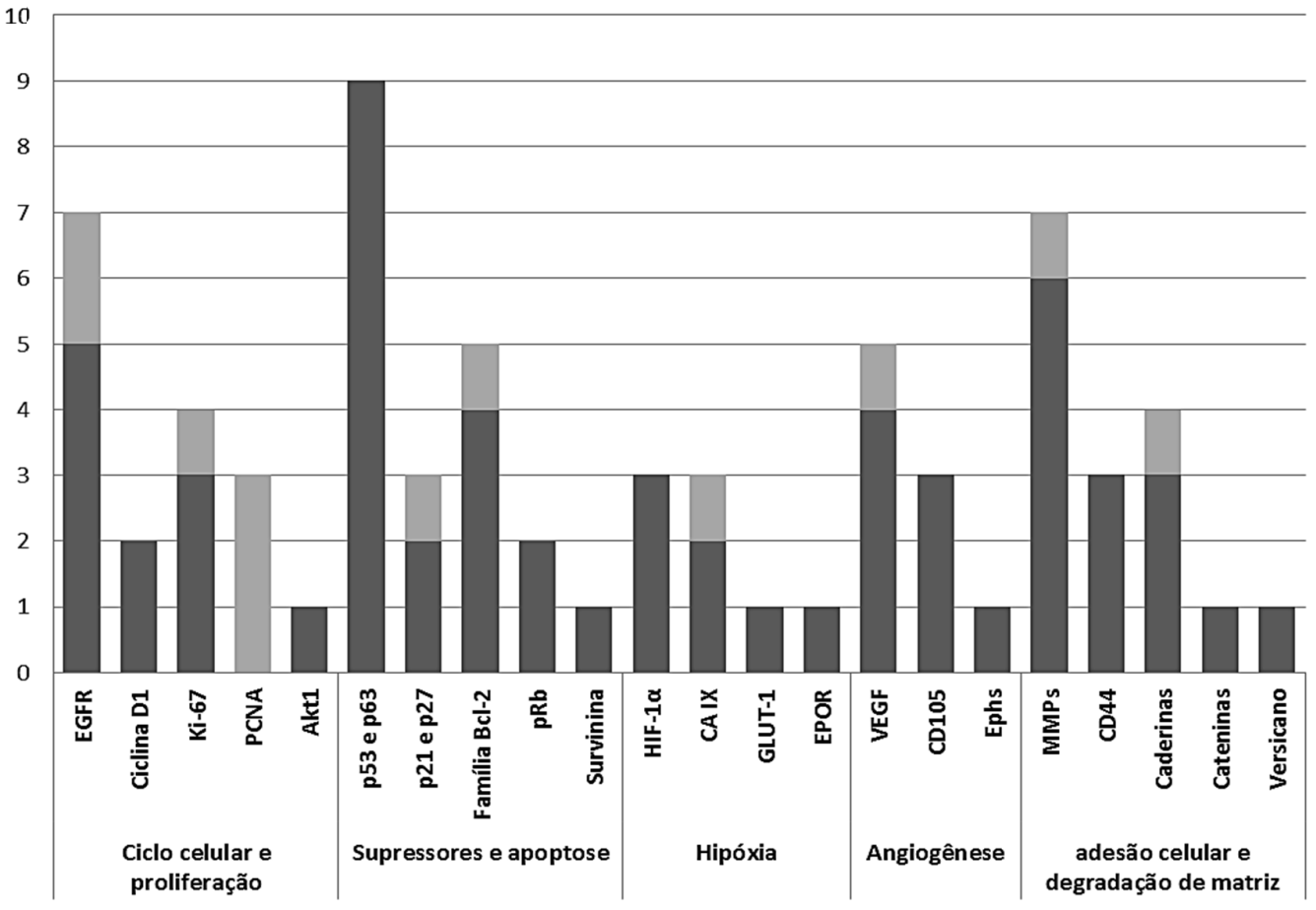

Figura 2.1 - Marcadores biológicos testados para o carcinoma epidermoide bucal e sua relevância como fator de prognóstico. A) Relação da classe dos marcadores levantados de estudos publicados no período de 1997-2002 [adaptado de Schliephake, 2003]. B) Relação e classe dos marcadores utilizados em imunohistoquímica nos estudos publicados no período de 2005 a 2009 para o CEB revisão [adaptado de Oliveira e Ribeiro-Silva, 2011] 


\subsection{METALOTIONEÍNA}

\subsubsection{Conceitos sobre a metalotioneína}

As Metalotioneínas (MTs) têm sido amplamente definidas na literatura como proteínas ubíquas de baixo peso molecular e alto conteúdo de cisteína. Tal designação deve-se inicialmente à sua existência em todos os organismos do reino animal, além de plantas superiores, microrganismos eucarióticos, e, ainda, alguns procariontes. Seu peso molecular é considerado baixo, variando entre 6 a 7 kilodaltons, e aproximadamente $20 \%$ deste é dado pelo conteúdo de enxofre e metais associados como Zinco (Zn), Cádmio (Cd), Mercúrio (Hg) e Cobre (Cu2+). A cisteína é o aminoácido mais representativo, compondo cerca de $30 \%$ dos $61-68$ aminoácidos de sua estrutura (Nordberg; Nordherg, 2009; Romero-Isart; Vasák, 2002).

O termo "Metalotioneína" foi utilizado pela primeira vez em 1960, após isolamento por Kägi e Vallee a partir de tecido renal equino, buscando entender a qual proteína se ligava o $\mathrm{Cd}$ adquirido por exposição contaminante destes animais. Os autores então descreveram uma proteína de conteúdo extremamente alto de enxofre $\left(4.1 \% \mathrm{~g}^{-1}\right.$ de peso seco), $\mathrm{Cd}(2,9 \%)$ e $\mathrm{Zn}(0,6 \%)$, que então nomeou de Metalotioneína (MT) (Nordberg, 1998). Desta maneira, entende-se que a proteína foi batizada de Metalotioneína utilizando o sufixo "metalo" para retratar esta afinidade por ligações metálicas, e "tio" para retratar sua riqueza em grupos tiol (também designados grupos mercaptano ou grupos sulfidrila) presentes nos aminoácidos cisteína. A MT possui uma gama de funções nos diversos seres vivos em que são encontradas, funções estas, principalmente relacionadas à habilidade ligante de metais da proteína, que se torna relevante na homeostasia e carreamento de diferentes átomos metálicos. A presente revisão se restringirá aos estudos das MTs de mamíferos. 


\subsubsection{Estrutura proteica da Metalotioneína}

Quatro isoformas ${ }^{1}$ proteicas foram descritas para mamíferos, denominadas MT1, MT2, MT3 e MT4. Embora as propriedades físico-químicas sejam semelhantes, existem algumas especializações de suas funções biológicas. A MT3 é encontrada principalmente no hipocampo, amídala e córtex (Hoey et al., 1997). Seu gene tem sido identificado em neurônios ricos em Zn e em astrócitos, tornando-se mais expresso após injúria cerebral, como já demonstrado em doenças degenerativas como doença de Alzheimer (Hozumi et al., 1996; Masters et al., 1994; Masters et al., 1994). A MT4 ainda é pouco conhecida e parece também exercer papel diferente de MT1 e -2 nas funções celulares. Sua presença foi descrita em epitélio estratificado de pele e mucosa bucal, principalmente restrita às camadas mais superficiais do epitélio, ao contrário das isoformas MT1 e MT2, expressas apenas nas camadas basal e parabasal (Quaife et al., 1994). As MTs são ubíquas, porém apenas MT1 e MT2 são altamente induzíveis, sendo que os eventos que induzem MT1 e MT2 geralmente não se refletem na indução de MT3 e MT4 (Haq et al., 2003). Até a presente data, as isoformas MT1 e MT2 são as mais bem estudadas e caracterizadas. São as que se encontram mais amplamente distribuídas pelos diferentes sistemas orgânicos, além de serem as mais responsivas aos estímulos indutores de sua expressão. Fisiologicamente está presente em maior quantidade no fígado, rins, pulmões, células epiteliais do timo, eritrócitos, e em muitas células pancreáticas exócrinas e endócrinas (Coyle et al., 2002b; Haq et al., 2003; Miles et al., 2000; Simpkins et al., 1998).

As MTs, como um todo, consistem basicamente em proteínas de 61 a 68 resíduos de aminoácidos, possuindo pequenas variações dentre elas, porém exibindo uma sequência principal que conserva a quantidade e posição dos resíduos de cisteína (Figura 2.2). Em sua porção N-terminal, as MTs são iniciadas por acetilmetionina (M), seguindo-se então para uma cadeia de aminoácidos organizados em ocorrências do tipo cisteína-x-cisteína, cisteína-x-y-cisteína, e cisteína-cisteína, sendo $x$ e y outros aminoácidos, frequentemente finalizando-se

\footnotetext{
${ }^{1} \mathrm{O}$ presente trabalho utiliza números indo-arábicos para descrever as isoformas da MT, seguindo a nomenclatura aprovada pela HUGO Gene Nomenclature Committee (HGNC), e a designação oficial da base de dados da SwissProt http://www.uniprot.org), MCBI (Medical Center for Biotechnology Information), e da base de dados da Human Genome Organization.
} 
com um resíduo de Alanina (A) na sua porção C-terminal. Não são observados aminoácidos aromáticos, havendo um ou nenhum aminoácido de histidina (Kägi; Kojima, 1987). Estudos com sequenciamento de proteínas definem que a única diferença consistente entre as isoformas MT1 e MT2, que são as mais amplamente distribuídas nos tecidos, é a presença de uma única carga negativa em MT2, dada pela presença de um resíduo de aspartato na posição 10 ou 11 da proteína, enquanto frequentemente Glicina é encontrada em uma posição correspondente na MT1 (Hamer, 1986; Peterson et al., 1988). A MT3 possui um resíduo extra de Treonina na posição cinco, alteração que tem importância no seu papel biológico neuro-inibitório, além de uma inserção sequencial de outros seis resíduos próximos à porção C-terminal (Cai et al., 2006a). A MT4 compartilha um resíduo adicional de Glutamato na posição cinco, próximo à porção $\mathrm{N}$-terminal. Até a presente data, as isoformas MT1 e MT2 são as mais bem estudadas e caracterizadas, representando a grande maioria dos estudos. São as que se encontram mais amplamente distribuídas pelos diferentes sistemas orgânicos, além de serem as mais responsivas aos estímulos indutores de sua expressão. A figura 2.2 ilustra os resíduos de cisteína altamente conservados dentre as diversas isoformas que conferem a propriedade metal-ligante das MTs. Pequenas trocas de aminoácidos também são evidenciadas, sendo que apenas algumas destas, descritas anteriormente, é que resultam em alterações funcionais.

Quanto à estrutura terciária, denotam-se duas porções distintas, como observado na figura 2.2, denominadas domínio a ou porção carboxi-terminal (Cterminal), e domínio $\beta$ ou porção N-terminal (Ngu et al., 2008; Winge; Miklossy, 1982). No domínio $\alpha$, tem-se sítio de ligação para até quatro compostos bivalentes como $\mathrm{Zn}^{2+}$ e $\mathrm{Cd}^{2+}$, e no domínio $\beta$ podem ligar-se outros 3 átomos, totalizando 7 átomos bivalentes (Figura 2.2). A configuração tridimensional final da MT é sempre dada pela interação entre seus demasiados resíduos de cisteína com os átomos metálicos, sendo observada maior afinidade para metais de transição do grupo lb (Cu2+ e Ag) e do grupo llb ( $\mathrm{Zn}, \mathrm{Cd}$ e Hg). A ligação CuMT é a forma mais comum após ZnMT (Haq et al., 2003; Kägi; Kojima, 1987; Romero-Isart; Vasák, 2002; Saber; Pişkin, 2003). Todos os resíduos de cisteína ocorrem na forma reduzida e são coordenados pelos íons metálicos por laços mercaptídeos, resultando nos achados espectroscópios característicos dos grupamentos metal-tiolatos (Romero-Isart; Vasák 2002). 
A)

$\beta$

a

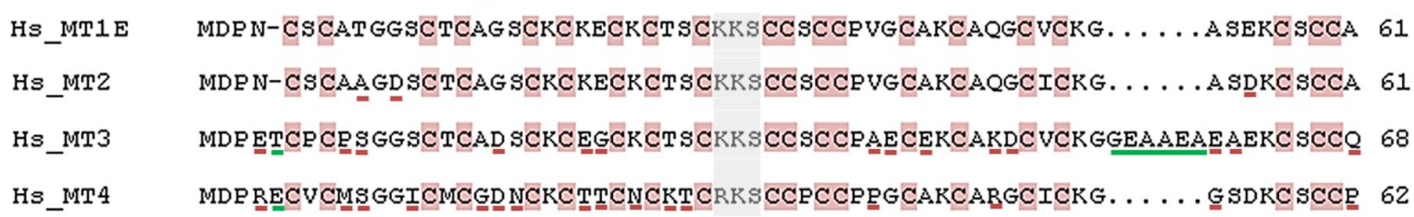

B)

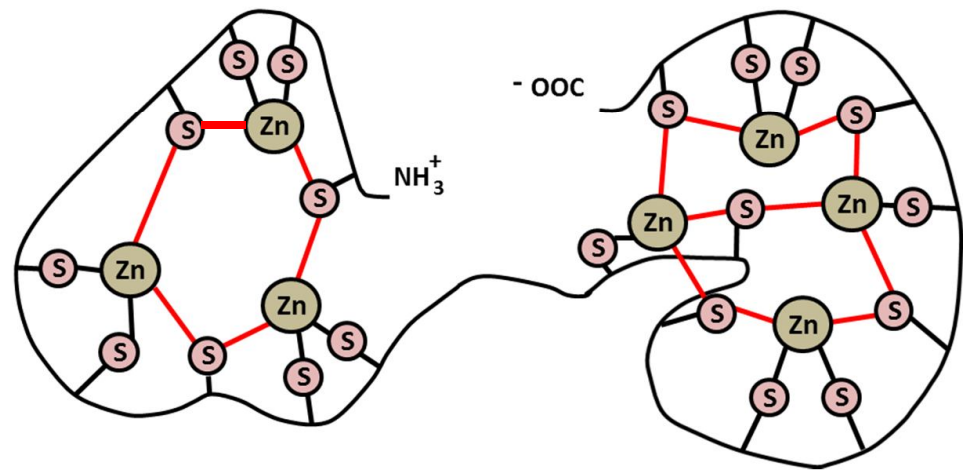

Figura 2.2 - Estrutura da MT mamífera saturada por Zinco (Zn). A) Sequência de aminoácidos que compõem a estrutura primária das diferentes isoformas proteicas da MT. As iniciais sombreadas de rosa representam os resíduos altamente conservados das MTs, presentes em todas as isoformas. Os aminoácidos divergentes da estrutura primária da MT1 estão sublinhados em vermelho, e as sequencias adicionais estão sublinhadas em verde [Adaptado de Moleirinho et al., 2011]. B) Esquema representativo do arranjo da MT formando os domínios $\alpha$ e $\beta$ em um exemplo saturado com Zn. Os radicais tiol (S) formam ligações diretas aos átomos de Zn [Adaptado de Fischer; Davie, 1998]

Estudos clássicos de espectroscopia relataram que os metais ligados à MT podem constituir até $11 \%$ do peso molecular da proteína (Nordberg; Nordherg, 2009). A estequiometria da MT dita que até 7 metais bivalentes, ou 12 metais monovalentes como $\mathrm{Cu} 2++, \mathrm{Ag}+$, e $\mathrm{Hg}+$, podem formar complexos com a MT. (Chen et al., 1996; Ngu et al., 2008; Nordberg; Nordherg, 2009). Vários fatores biológicos influenciam a composição metálica da MT, como origem tecidual, idade e estágio de desenvolvimento. Por exemplo, a MT hepática pode conter principalmente Zn e Cu2+, enquanto a MT renal pode conter Cd, Cu2+ e Zn (Nordberg, 1998). O Zn parece ser o metal mais prevalente nas condições fisiológicas, seguido de Cu2+, 
porém, uma afinidade distinta de ligações metálicas pode ser observada in vitro: $\mathrm{Zn}^{2+}<\mathrm{Pb}^{2+}<\mathrm{Cd}^{2+}<\mathrm{Cu}^{2+}<\mathrm{Ag}^{+}=\mathrm{Hg}^{2+}=\mathrm{Bi}^{3+}$. Muitos destes metais são considerados tóxicos (exceto $\mathrm{Zn}$ e $\mathrm{Cu}$ ) e podem deslocar e substituir prontamente o zinco (Coyle et al., 2002; Kägi; Kojima, 1987). Mesmo assim, o conteúdo de Zn nunca é nulo, prevalecendo pelo menos um átomo residual de $\mathrm{Zn}$ na proteína sob as variadas condições (Cherian et al., 2003; Nordberg; Nordherg, 2009). Quando todos os sítios disponíveis para ligações metálicas estão ocupados por $\mathrm{Zn}$, apenas dois átomos desse metal estão disponíveis para doação rápida a outras proteínas. Estes se encontram ligados ao domínio $\beta$ e dispostos mais superficialmente em relação à conformação espacial da metalotioneína (Miles et al., 2000; Romero-Isart; Vasák, 2002). A transferência intermolecular in vitro de Zn entre a MT saturada e outras proteínas de $\mathrm{Zn}$ foi estudada, indicando ativação de apoenzimas e modulação de fatores de transcrição após interação com a MT, mostrando que a MT é capaz de transferir um íon de $\mathrm{Zn}$ para outras proteínas que possuem uma afinidade bem menor pelo íons do que a MT como um todo (Hidalgo et al., 2009).

A apo-MT, ou, simplesmente, tioneína (T), é a forma proteica das MTs livre de ligações metálicas, o que ocorre após sua transcrição. Inicialmente, pensou-se que a MT fosse dependente das ligações metálicas para adquirir configuração funcional e estabilidade, pois os estudos in vitro demonstravam que a apo-MT corresponderia a uma forma proteica empacotada e sem definição, muito instável, degradando-se rapidamente caso nenhuma ligação metálica acontecesse em curto espaço de tempo (Feldman et al., 1978; Klaassen et al., 1994). Entretanto, os resultados destes estudos in vitro não foram compatíveis com os resultados de estudos in vivo. Os últimos demonstraram que a apo-MT possui estabilidade semelhante à da MT ligada a metais. Além disto, estes estudos demonstram que há uma presença constante de apo-MT e MT ligada a metais nos ambientes celulares, ambas coexistindo em um balanço dinâmico que é variável de acordo com as condições do meio, como por exemplo, com relação à disponibilidade de Zn (Duncan et al., 2006; Kraker et al., 1988; Petering et al., 2006; Yang et al., 2001). A literatura revela certo paradigma teórico sobre esta duplicidade de conceitos, sendo que mesmo em trabalhos mais recentes, ainda pode ser observado o conceito de instabilidade e curta meia-vida da apo-MT (Davis; Cousins, 2000; Nordberg; Nordherg, 2009). Com relação à estrutura terciária da apo-MT, foi demonstrado por Rigby e seus colaboradores que há um dobramento firme das cadeias peptídicas de maneira que 
os radicais tiol ficam mais superficiais, conferindo potentes propriedades ligantes à apo-MT (Rigby; Stillman, 2004). Estudo recente demonstra haver espectros semelhantes de massa e volume em $\mathrm{pH} 7$ para apo-MT e MT ligada a metais, desmistificando que a dobragem da apo-MT é desorganizada e concluindo que a dobragem de ambas as formas é muito semelhante no pH neutro (Summers et al., 2012).

\subsubsection{Regulação gênica da Metalotioneína}

Em humanos, mais de 10 genes são responsáveis pela transcrição da MT, todos localizados em uma cadeia gênica de aproximadamente 82 kb no cromossomo 16, limitados pelos genes BBS e NUP3, orientados de centrômero para telômero na sequência MT4-MT3-MT2-MT1, como ilustrado na figura 2.3. Este número elevado de genes está principalmente relacionado a duplicações do gene codificante de MT1, decorrentes do processo de evolução da espécie humana, sendo que, em ratos, por exemplo, existe apenas um gene ativo para cada isoforma proteica. Assim, em humanos, MT1 é codificada por 13 genes, 8 funcionais (MT1A, MT1B, MT1E, MT1F, MT1G, MT1H, MT1M e MT1X) e 5 são inativos (MT1LP, MT1JP, MT1DP, MT1CP, MT1IP). Para as outras isoformas, há apenas um gene codificante ativo, a saber: MT2A (MT2B foi descrito como um pseudogene), MT3 e MT4 (Moleirinho et al., 2011).

Uma grande variedade de estímulos pode induzir a expressão de MT. Os estudos fornecem evidências de que as isoformas são reguladas de maneira independente, diferente do que ocorre em ratos, onde as isoformas MT1 e MT2 são reguladas de maneira coordenada (Yagle; Palmiter, 1985). Descreve-se na literatura que a MT3 (em níveis de proteína e ARNm) e a MT4 (em níveis de ARNm) são constitutivamente expressas em alguns tecidos e células, enquanto MT1 e MT2 são expressas em níveis basais, porém altamente induzíveis. Geralmente, os eventos que induzem MT1 e MT2 geralmente não refletem em indução de MT3 e MT4 (Haq et al., 2003). A expressão do gene $M T 2 A$ parece ser predominante em tecidos neoplásicos, somando-se quase $50 \%$ da expressão total da MT. Por outro lado, em 
tecidos cerebrais, há um predomínio de MT3, que soma cerca de $30 \%$ do total de expressão gênica (Hidalgo et al., 2009). Estas diferenças de ativação são indicadores das funções biológicas distintas das MTs.

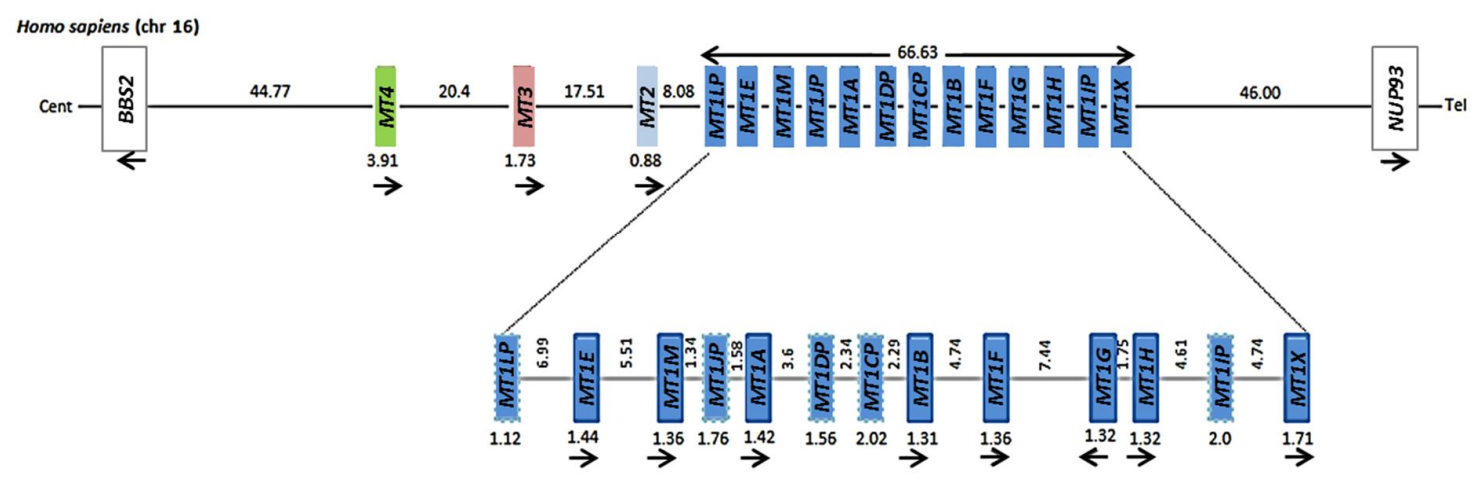

Figura 2.3- Ilustração da família gênica da Metalotioneína no cromossomo 16q13. Há um gene único para MT2 (em azul claro), MT3 (em rosa) e MT4 (em verde), enquanto 8 genes funcionais codificam a MT1 (em azul escuro). Em azul escuro, com margens tracejadas observam-se os genes não funcionais ou pseudogenes de MT1. A direção de transcrição está indicada pela flexa. Os números descritos representam o tamanho das regiões dos genes em Kb [adaptado de Moleirinho et al. 2011]

Segundo uma revisão sobre a história das MTs, Piscator foi um dos pioneiros em 1964 ao perceber um dos mecanismos mais eficientes de ativação da MT, que é a exposição a íons metálicos. O autor descobriu durante seus experimentos com coelhos, que quando uma dose letal de Cd era fracionada em doses menores, havia sobrevida dos animais. Tal evento foi acompanhado de aumento significativo de MT hepática (Nordberg et al., 1972; Nordberg, 1998). Desde então, foi reconhecida a grande importância da exposição metálica como estímulo transcricional de MTs. Esta potente indução por metais ocorre pela existência de múltiplas cópias na região promotora de elementos responsivos ao metal (MRE, do inglês metal response elements), que são elementos regulatórios Cis-atuantes, ou seja, estão junto aos genes das MTs na região promotora. Há uma variabilidade de capacidade indutora dentre MREs distintos, sendo que um mesmo metal estimular intensamente determinada isoforma da MT e não provocar nenhuma transcrição para outra isoforma (Miles et al., 2000). Um estudo que avaliou o mecanismo de ativação de 7 
MREs distintos no gene MT2A concluiu que estes elementos podem mediar a resposta a íons metálicos de maneira sinérgica porém independente. Estes pesquisadores fizeram um estudo com transfecção de 7 MREs do gene MT2A para células HeLa. Destes, apenas quatro mostraram-se ativos aos estímulos do meio de cultura com $\mathrm{ZnSO}_{4}, \mathrm{HgCl}_{2}$ e $\mathrm{CdSO}_{4}$. Os elementos denominados MREa e MREe mostraram maior potência de ativação da transcrição gênica do que os elementos MREb e MREg, enquanto que os elementos MREc, $d$, e f, não foram responsivos a nenhum dos metais (Suzuki; Koizumi, 2000).

Estudos utilizando extrato nuclear de células HeLa revelaram duas proteínas que agem como fatores de transcrição das MTs junto aos MREs, a proteína ligante de MRE (MREBP), que se liga especificamente às MREs do gene MT2A, e o fator transcricional ligante de MRE 1 (MTF-1), um fator de transcrição constitutivamente ativo e sensitivo ao Zn. MREBP parece ser um inibidor da transcrição, enquanto MTF-1 parece ser proteína importante na regulação metal-induzida das MTs (Davis; Cousins, 2000). Palmiter propôs que o MTF-1 constitutivamente ativo está sob controle de um inibidor de transcrição da MT metal-sensitivo (MTTI, do inglês metallothionein transcription inhibitor), que previne a interação entre MTF-1 e os MREs. Foi observado que o Zn seria o único responsável pela dissociação de MTTI do MTF-1, que então libera MTF-1 para interação com os MREs. Logo, em uma situação de aumento de Zn nos ambientes celulares, o MTF-1 torna-se ativo, estimulando a transcrição das MTs, que, por conseguinte, restaura o equilíbrio normal de Zn após ação quelante no metal (Palmiter, 1994). Quando as células são submetidas a uma carga de metais pesados, o MTF-1 transloca-se para o núcleo e liga-se ao MRE induzindo a transcrição (Davis; Cousins, 2000; Nordberg; Nordherg, 2009). Entretanto, um estudo posterior demonstra uma complexidade maior de ação de MTF-1, onde os autores demonstram a presença do fator de transcrição IID (TFIID; do inglês transcription fator IID) e do mediador (MED). Neste estudo, os autores afirmam que o MTF-1 recruta o TFIID que então se liga ao MRE, porém apenas induz a transcrição após ligação de MED, formando um complexo de subunidades para ocorrer a ativação, levando a um controle rigoroso da transcrição (Marr et al., 2006).

Em uma visão geral, os MREs são os principais responsáveis pela iniciação da transcrição, porém, o mecanismo como um todo é complexo e ainda não se sabe quantos tipos diferentes de fatores podem se ligar e estimular os MREs. Assim, 
observa-se que as isoformas gênicas da MT respondem de maneira distinta ao mesmo estímulo metálico, e que metais diferentes possuem capacidades diferentes de indução de cada isoforma. Por exemplo, a capacidade de indução metálica mostrou-se variável e metal-específica para os genes da MT em estudo clássico que utilizou células malignas HepG2 de origem hepática. Neste estudo, observou-se transcrição aumentada de $M T 1 G$ e $M T 1 F$ logo após a primeira hora de exposição ao $\mathrm{Zn}$, enquanto que resultado semelhante de indução por $\mathrm{Cd}$ ou $\mathrm{Cu}$ somente foi obtido após duas horas de exposição. O Cd foi retratado como pior indutor de MT1G, enquanto que o $\mathrm{Cu}$ é que foi o pior indutor de MT1F. Por outro lado, após longos períodos (> 4 horas), a exposição ao Cu resultou no maior nível de transcritos para MT1G quando comparado ao obtido com indução por Zn e Cd em período semelhante. Para o gene MT2A observa-se um padrão de detecção relativamente maior desde a mensuração basal, e um padrão de resposta muito semelhante para indução seja por Zn, Cu ou Cd. A quantidade de máxima obtida de transcritos de MT2A foi cerca de 75.000-85.000 moléculas, comparado aos 12.000 de MT1G e 4.000 de MT1F (Sadhu; Gedamu, 1988). Em outro estudo, avaliando o potencial de indução de $\mathrm{Cd}$ em células KAT5, de neoplasia maligna de tireoide, observa-se graficamente uma distinção entre o tempo e a expressão de cada isoforma gênica da MT. Um pico em resposta de MT1E foi obtido logo em 3 horas de observação. Entretanto, as isoformas gênicas de maior expressão começaram a responder mais significativamente após 24 horas, sendo que ao final de 72 horas, obtém-se alto padrão de indução para indução de $M T 1 A, M T 1 F, M T 1 G, M T 1 H, M T 1 X$, e MT2A, e quantidade relativamente insignificante de $M T 1 B$ e $M T 1 E$ (Liu et al., 2009). Tais resultados sugerem a existência de uma família de fatores de transcrição, bem como de inibidores de transcrição, que podem ser específicos para cada MRE de cada isoforma gênica.

Um aumento de transcrição das MTs também pode ser resultante de situações de estresse, presença de hormônios (glucagon, glicocorticoides), AMPc, interleucinas 1 e 6, intérferon, e fator de necrose tumoral (Davis; Cousins, 2000). Muitas destas respostas serão atribuídas à presença de outros elementos nas regiões promotoras dos genes das MTs: elementos responsivos ao glicocorticóide (GRE); elementos responsivos a antioxidantes (ARE); outros elementos. Nem todos os genes das MTs contêm todos estes elementos. Sabe-se, por exemplo, que a exposição metálica é capaz de induzir todos os genes da MT, enquanto 
glicocorticoides apenas induzem MT2A e MT1E. Um modelo complexo de comportamento de expressão gênica da MT foi elaborado para as condições de inflamação hepática (Coyle et al., 2002). Em condições como esta, interleucina I (IL1), fator de necrose tumoral (TNF- $\alpha$ ) e interleucina 6 (IL-6) são comumente liberados por linfócitos T e macrófagos. A IL-6 e outras proteínas da fase aguda fosforilam a tirosina de proteínas transdutoras de sinais e ativadoras da transcrição (STATs; do inglês "Signal Transducer and Activator of Transcription, or Signal Transduction And transcription"), que interagem com regiões promotoras do gene da MT (Lee et al.,, 1999). Os glicocorticóides também serão liberados em resposta ao estresse e às citocinas descritas, que estimulam o eixo pituitária/adrenal. Os glicocorticóides ligamse aos elementos responsivos aos glicorticóides (GREs), e o aumento de transcrição de MT induzido pelos mesmos pode culminar no sequestro de $\mathrm{Zn}$ no plasma e aumento de sua disponibilidade intracelular, que poderá interagir com MREs após liberação. As citocinas também causam expressão variável das isoformas da MT nos diferentes tecidos, com IL-6 e TNF- $\alpha$ induzindo mais MT2 do que MT1 no fígado, enquanto TNF-a é um forte indutor de MT1 nos pulmões e coração (Sato e Bremmer, 1993). Catecolaminas e glucagon induzidos pelos mediadores inflamatórios atacam receptores de membrana e, por meio de sistema de mensagem secundária agem ativando fatores nucleares trans-ativos que interagem com elementos controladores ainda não identificados. Espécies reativas de oxigênio formados durante a inflamação podem interagir com os AREs e outros elementos regulatórios (Coyle et al., 2002b). A figura 2.4 representa um modelo estimado da complexidade de ativação gênica das MTs, porém limitado ao conhecimento ainda restrito sobre a quantidade e especificidade dos fatores indutores.

Finalmente, os mecanismos de controle transcricional das MTs ainda merecem novas investigações para melhor entendimento do funcionamento distinto observado para cada uma das isoformas gênicas. Além disto, ainda existem evidências que apontam para mecanismos de regulação pós-transcricional da MT. Tais eventos foram observados a partir de discrepâncias entre a expressão gênica e a quantificação proteica. Por exemplo, o tratamento com $\mathrm{Cu}$ em ratos reduz a expressão renal de MT1 e MT2 ao passo que aumenta a expressão proteica das isoformas em conjunto. O tratamento destes animais com $\mathrm{Cd}$ aumenta os níveis de ARNm de MT1 e MT2 porém não altera os níveis de proteína, além de aumentar consideravelmente mais o gene MT1 do que MT2 no fígado dos animais 
(Vasconcelos et al., 2002). A exposição de células humanas tipo HepG2 ao Zn induz rapidamente a expressão gênica de $M T 1 G$ e $M T 1 F$, porém atinge um potencial máximo de indução precoce em relação ao observado após exposição ao $\mathrm{Cd}$ e $\mathrm{Cu}$, seguindo então para um declínio de expressão (Sadhu; Gedamu, 1988). Desta forma, ainda existem muitos mistérios envolvendo os mecanismos celulares que regulam a expressão e funcionamento das MTs, que por sua vez representam proteínas extremamente versáteis e com potencial de participação em diversas funções celulares, como discutido no capitulo seguinte.

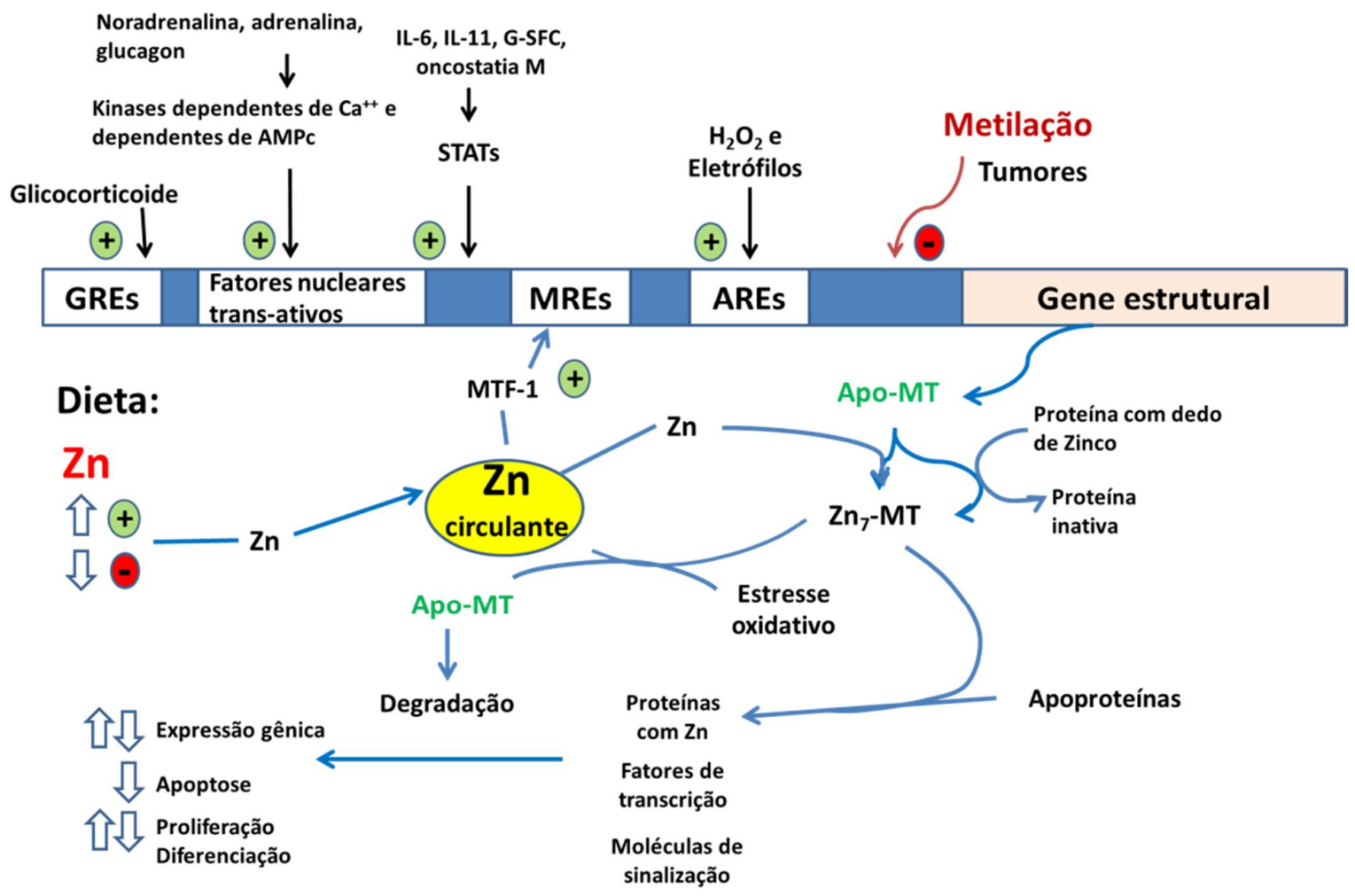

Figura 2.4 - Modelo representativo das interações potencialmente ativas na regulação de expressão das Metalotioneínas [modelo adaptativo das interações representadas por Coyle et al. (2002) e Davis e Cousins (2000)] 


\subsubsection{Aspectos funcionais da Metalotioneína}

As MTs, principalmente a 1 e a 2, são comumente referidas na literatura inglesa como uma "housekeeping protein", ou seja, está sempre presente no ambiente celular, normalmente em pequenas quantidades, atuando em diversas funções celulares, como será descrito nos subtítulos seguintes (Cherian et al., 2003). Em humanos, níveis basais da expressão do gene MT2 parecem ser maiores do que os de MT1. Richards e colaboradores (1984) mostraram que o gene MT2A esteve aproximadamente cinco vezes mais expresso do que o conjunto dos genes MT1 em células HeLa, células TK de osteossarcoma, e em fibroblastos da pele humana, sugerindo que a MT1 é pobremente expressa, e que a o gene MT2A possui atividade constantemente aumentada. Como dito anteriormente, até a presente data, as isoformas MT1 e MT2 são as mais bem estudadas e caracterizadas, principalmente por serem mais amplamente distribuídas pelos diferentes sistemas orgânicos e as mais responsivas aos diversos estímulos indutores de sua expressão. Há uma predileção nítida de expressão de MT3 em tecidos neurais, como hipocampo, amídala e córtex cerebral, onde foi descrita inicialmente como um fator inibidor do crescimento neuronal (denominado GIF, ou Growth Ihibitory Factor (Masters, 1994). A MT4 ainda é pouco conhecida, sendo que os poucos estudos existentes descreveram similaridades quanto à sua propriedade metal ligante, porém a mesma parece exercer papel diferente de MT1 e MT2 nas funções celulares. A expressão de MT4 foi descrita em epitélios estratificados como o da mucosa bucal. Foi observado que nesses tecidos a MT4 encontra-se restrita às camadas mais superficiais do epitélio, ao contrário das isoformas MT1 e MT2, expressas apenas nas camadas basal e parabasal, indicando alguma associação da isoforma MT4 com a diferenciação epitelial (Quaife et al., 1994). Uma dedução óbvia seria de uma possível participação da MT4 no processamento da queratina, onde o fator de transcrição Whn parece estar envolvido (Schlake; Boehm, 2001).

A MT está presente em muitos tecidos sadios, tais como células do parênquima hepático, rins, pulmões, células epiteliais do timo, eritrócitos, e muitas células pancreáticas exócrinas e endócrinas. Tem sido proposto que níveis de MT são elevados em tecidos que estejam em rápido crescimento e desenvolvimento, geralmente para fornecer $\mathrm{Zn}^{2+}$ e $\mathrm{Cu}^{2+}$ para o metabolismo de ácidos nucléicos, 
síntese de proteínas, e outros processos (Davis; Cousins, 2000; Nordberg 1998; Nordberg; Nordherg, 2009; Richards, 1989; Vasconcelos et al., 2002). Em pessoas sadias, o nível de MT detectado por radioimunoensaio é de $1-16 \mu \mathrm{g} / \mathrm{L}$ no plasma ou soro e de 5-400 $\mathrm{\mu g} / \mathrm{g}$ em creatinina na urina (Kille et al., 1993). Em mulheres idosas expostas ao $\mathrm{Cd}$ do ambiente normal, e em trabalhadores expostos ao $\mathrm{Cd}^{2+}$, os valores são 2-155ng MT/g e no plasma de 2-11ng MT/g. A urina torna-se um bom indicador dos níveis de contaminação por exposição a metais pesados. Em tecidos de fígado humano sem alteração patológica aparente, os níveis de MT variam de 0$104.5 \mathrm{mg} \mathrm{MT} / \mathrm{g}$. As concentrações normais de MT em tecidos de ratos determinados por ELISA são $18 \mu \mathrm{g} / \mathrm{g}$ em fígado, $30 \mu \mathrm{g} / \mathrm{g}$ em rins, e $35 \mu \mathrm{g} / \mathrm{g}$ no córtex renal (Kay et al., 1991; Willner et al., 1987).

Diferenças entre o sexo masculino e o feminino também foram relatadas. Mulheres têm maior concentração de MT na urina quando comparado aos homens, mesmo em níveis similares de exposição ao $\mathrm{Cd}^{2+}$. Além disso, as mulheres parecem possuir concentrações maiores $\mathrm{Cd}^{2+}$ no sangue e no fígado, mesmo quando este é sobrecarregado por hábitos de fumo ou exposicionais (Nordberg, 1998; Nordberg; Nordherg, 2009). A hipótese de menor quantidade de MT tecidual em negros também já foi descrita, porém sem maior consistência (Gallicchio et al., 2005). A concentração celular de MT também parece ser idade-dependente, sendo que tendo sido relatado um declínio após os 60 anos. Isto pode acontecer devido à capacidade do tecido renal em produzir MT, sendo que a produção da proteína é menos eficiente em uma idade biológica avançada (Nordberg, 1998; Nordberg; Nordherg, 2009).

Os estudos mostram participação da MT em muitos outros processos patofisiológicos como homeostasia de metais, eventos oxidatinos, apoptose, proliferação celular, e angiogênese. 


\subsubsection{Homeostasia de Metais}

Metais estão amplamente distribuídos no meio ambiente e são componentes naturais da biosfera. Devido à sua natureza persistente e baixa eliminação dos compartimentos ambientais, são um dos maiores e mais abundantes grupos de microcontaminantes, e encontram-se no ambiente associados a vários elementos. Embora não possam ser criados ou destruídos, metais podem ser redistribuídos em escala regional e global. Alguns metais, como sódio, potássio, cálcio, ferro, zinco, cobre, níquel e magnésio são elementos essenciais para o metabolismo normal do organismo. Porém, principalmente com os adventos da revolução industrial, muitos metais tóxicos como arsênico, chumbo, cádmio, mercúrio, alumínio, titânio, estanho e tungstênio começaram a ser mobilizados de suas fontes naturais e assim deslocados por todo globo. Os mecanismos de exposição incluem hábitos nocivos como o tabagismo $\left(\mathrm{Cd}^{2+}, \mathrm{Pb}^{2+}\right)$; contato com produtos industrializados como tinturas, esmaltes, baterias automotivas, solventes; e exposições a ambientes contaminados com queimas de carvão, poluição industrial, agrotóxicos, etc (Pascalicchio, 2002).

Desde os estudos iniciais que levaram à descoberta das MTs, como o estudo clássico de Margoshes e Vallee em 1957, as MTs têm sido referenciadas como proteínas de singular potencial de interação com íons metálicos. O consenso geral dos estudos é de que a exposição metálica em animais (seja por dieta ou ambiental) resulta em uma elevação consistente da expressão das isoformas MT1 e MT2 (MT1/2, explicadas mais adiante), principalmente no fígado. Além disto, a exposição a íons metálicos para animais knockout para MT1/2 leva à toxicidade dos mesmos, enquanto que animais que apresentam expressão aumentada de MT1/2 tornam-se relativamente protegidos de toxicidade metálica (Coyle et al., 2002). As pessoas que residem em áreas onde há alta exposições ambiental a estes metais, também exibem elevados índices de MT1/2 ligada aos mesmos (Hidalgo et al., 2009). De maneira semelhante, os metais de exposição também aparecem no ambiente intracelular ligados às MTs. O aumento excessivo de determinado metal intracelular poderá ser capturado pela MT existente ou induzir novas proteínas a partir da ativação de elementos responsivos a metais (MREs) existentes em todos os genes das MTs. Sabe-se que muitos dos metais tóxicos possuem afinidade pelas MTs suficiente para deslocar o $\mathrm{Zn}^{2+}$ ou $\mathrm{Cu}^{+}$da MT existente. No entanto, 
secundariamente a esta reação, poderá haver um aumento excessivo de $\mathrm{Zn}^{2+}$ intracelular. Por isto, acredita-se que a presença de apo-MTs tem papel fundamental nesta homeostasia (Hidalgo et al., 2009).

$\mathrm{O} \mathrm{Zn}^{2+}$ é um metal essencial e parece ser o metal mais comumente ligado às MTs. Este metal é componente de várias proteínas e está envolvido em todos os aspectos do metabolismo, sendo parte integral de aproximadamente 300 enzimas em diferentes espécies de todos os filos, indispensáveis às suas funções, as quais envolve o início, a síntese e/ou a degradação da maioria dos metabólitos. O $\mathrm{Zn}^{2+}$ estabiliza a estrutura de proteínas e ácidos nucléicos, preserva a integridade de organelas sub-celulares, participa em processos de transporte, e desempenha um importante papel em fenômenos imunológicos (Frassinetti et al., 2006). Os níveis de $\mathrm{Zn}^{2+}$ no fígado são extremamente importantes no controle da síntese e degradação da MT na maioria das espécies animais, de modo que as concentrações de MT nos hepatócitos são muito baixas na deficiência de $\mathrm{Zn}^{2+}$ e a síntese da proteína é estimulada com suplementação de $\mathrm{Zn}^{2+}$ na dieta (Vallee, 1995; Dufner-beattie et al., 2003). Nestas situações de deficiência de zinco, demonstrou-se que a apo-MT atua como forma predominante, evidenciando também o mecanismo de transporte reversível destes íons (Yang et al., 2001). Desta forma, o mineral pode ser liberado das MTs para ser utilizado nas diversas funções celulares em que está envolvido, ou pode ser captado quando o mineral atinge níveis elevados, protegendo a célula contra a toxicidade (Dufner-Beattie et al., 2003; Tom et al., 2003). Outras proteínas como transportadores de zinco, conhecidos como Zip (zinc iron permeasse), envolvidos na captação de $Z^{2+}$ para o ambiente intracelular, e os ZnTs (Zinc transportes), que são proteínas de membrana envolvidas no afluxo de $\mathrm{Zn}^{2+}$ também participam deste processo (Seve; Chimienti et al., 2004). Ambos são induzidos mediante presença do metal, porém sem relação direta com a transcrição da MT (Datta et al., 2007).

O $\mathrm{Cd}^{2+}$ é um poluente ambiental tóxico para numerosos tecidos. Uma exposição aguda ao $\mathrm{Cd}^{2+}$ produz danos hepáticos, pulmonares e testiculares, e a exposição crônica pode causar injúria renal e câncer, bem como toxicidade a outros órgãos (Klaassen et al., 1999). Numerosos estudos sugerem a importância da MT na disposição e desintoxicação do $\mathrm{Cd}^{2+}$. Os animais knockout para MTs expostos ao $\mathrm{Cd}^{2+}$ são mais susceptíveis à injúria renal, com maior excreção de proteínas, glicose, aumento de ureia sanguínea, degeneração tubular proximal, apoptose, atrofia e 
inflamação renal. Danos hepáticos também se tornam frequentes, caracterizando-se por hepatomegalia e apoptose (Klaassen et al., 1999).

Um papel funcional no armazenamento e desintoxicação pelo $\mathrm{Cu}^{2+}$ também tem sido proposto, porém mais relacionado à proteção contra toxicidade do que com relação à distribuição funcional e fisiológica do metal (Klaassen et al., 1999). Outros metais de alta tecnologia como gálio, telúrio, ítrio, nióbio, tálio, e bismuto e outros compósitos introduzidos recentemente em supercondutores como óxido de ítriobário-cobre (YBCO) e $\mathrm{Bi}_{2} \mathrm{Sr}_{2} \mathrm{Ca}_{2} \mathrm{Cu}_{3} \mathrm{O}_{10}$ (BSCCO) provavelmente também induzem MT. Pesquisadores defendem a ideia de que a aferição dos níveis de MTs nos trabalhadores expostos a riscos ocupacionais possa ser interessante assim que as técnicas de mensuração se tornem mais precisas e aplicáveis (Nordberg; Nordherg, 2009).

Não se sabe se os resultados destes estudos que avaliam sempre MT1/2 podem ser validados para as isoformas MT3 e MT4. Acreditava-se inicialmente que a MT3 não poderia ser induzida por metais, fato que é questionado em outros artigos que demonstraram a expressão da MT3 após tratamentos celulares com metais como o $\mathrm{Cd}^{2+}$ e o $\mathrm{Zn}^{2+}$ (Hoey et al., 1997). Estudo avaliando camundongos knockout para MT3 mostraram participação da MT3 na regulação do Zn durante a estimulação dos neurônios ricos em Zn GABA-enérgicos (Erickson et al., 1997). Ainda não existem estudos consistentes avaliando o potencial indutivo e funções correlatas à MT4.

\subsubsection{Potencial antioxidante}

Está bem estabelecido que metais tóxicos como o Cd podem induzir danos oxidativos pela produção de espécies reativas de oxigênio, além de causar prejuízo de atividade de outras enzimas antioxidantes como a superóxido desmutase, catalase e glutation peroxidase. O Cd também tem sido relacionado a danos a lipídeos e assim gerando peroxidação lipídica (Chen et al., 2008; Jihen et al., 2009; Liu et al., 2008). Um mecanismo semelhante ao daquele descrito para o metabolismo do $\mathrm{Cd}$ também ocorre com o $\mathrm{Cu}^{2+}$. A MT com sua propriedade metal 
ligante também poderia sequestrar o $\mathrm{Cu}^{2+}$ e preservar sua participação em reações redox e assim inibir a formação de radicais livres (Bremner, 1998). A afinidade de ligações destes metais às MT1/2 é maior do que a do $Z n$, neste sentido, poderiam prontamente substituí-lo. No entanto, como já dito, a participação das apo-MTs tem sido apontada como crucial nestes eventos.

O primeiro estudo sugerindo que MT1/2 podem ser consideradas proteínas antioxidantes foi publicado em 1982, em um relato demonstrando uma resistência significativamente aumentada à radioterapia em células de cultura com aumento de MT1/2. Em seguida, outro estudo importante foi o de Thornalley e Vasak (1985), demonstrando que estas proteínas são sequestradores eficientes de radicais de hidroxilas livres $\left({ }^{*} \mathrm{OH}\right)$ e superóxidos $\left(\mathrm{O}_{2}{ }^{*}\right)$ produzidos por reações xantina/xantina oxidase. Após esta descoberta, muitos estudos confirmaram que as MTs podem reagir com numerosos radicais livres, e que na maioria das vezes, condições prooxidantes induzem síntese de MT1/2, principalmente via AREs, mas também via MREs em algumas condições (Miura et al., 1997; Pitt et al., 1997; Elgohary et al., 1998; Kumari et al., 1998; Hidalgo et al., 2009).

Um estudo testou a capacidade antioxidante da MT utilizando MT1/2 extraída de fígado de coelhos em meio contendo compostos que liberam óxido nítrico (ON). O estudo comprovou a redução dos reagentes oxidantes nos meios contendo MT, mostrando ainda que na forma de apo-MTs a proteína possui capacidade antioxidante superior. No mesmo trabalho, os autores ainda submeteram cultura de células TE671 e LLC-PK aos mesmos agentes indutores de ON, observando que a proteção celular se deu de maneira simultânea pela ação das MTs e de componentes de baixo peso molecular que contém radicais tiol, bem como de Glutation, ressaltando que houve pequena detecção de deslocamento de $\mathrm{Zn}$ nas reações, ou seja, parece haver maior ação de apo-MTs neste processo (Zhu et al., 2010). Contribui com este achado o resultado de outro estudo, mostrando que a exposição ao ON de células TE671 pré-tratadas com Zn para indução de MTs, resulta em reação quase que exclusiva com a fração de apo-MT dentro da somatória total de MTs nas células (Petering et al., 2006).

As funções antioxidativas e citoprotetoras das MTs podem ter alta significância no estabelecimento de protocolos terapêuticos para determinados tipos de tumores, sendo que estes mecanismos funcionam como resistência à toxicidade da radiação e do tratamento quimioterápico (Nielsen et al., 2007; Theocharis et al., 
2004). Postula-se que o incremento na expressão da proteína em células e tecidos irradiados seja mediado pelos próprios radicais livres ou por citocinas liberadas em função do dano celular (Chu, 1994; Haq et al., 2003). Com relação à quimioterapia, drogas como vinblastina, cisplatina, mitomycina $\mathrm{C}$, doxorubicina, camptothecina, inostamicina, neocarzinostatina, dentre outras, exercem atividade antitumoral por meio de produção de ROS, que ativa a morte celular principalmente por apoptose (Fang et al., 2007). Nestes aspectos as MTs exercem um papel indesejado por possuir elementos gênicos que respondem aos agentes oxidantes, e consequentemente a maior concentração celular de MT funciona como mecanismo protetor contra espécies reativas do oxigênio (EROs), levando ao sequestro dos agentes oxidantes responsáveis pela interação com o ADN ou outra estrutura que levaria a destruição celular, o que representa assim um mecanismo de resistência celular ao tratamento oncológico (Cherian et al., 2003; Theocharis et al., 2004; Thirumoorthy et al., 2007).

\subsubsection{Atuação da Metalotioneína no processo neoplásico}

Diversos estudos confirmam que as MTs estão direta ou indiretamente envolvidas em mecanismos importantes do desenvolvimento neoplásico. Os estudos tem focado no significado das MTs em eventos envolvidos na carcinogênese, bem como na progressão tumoral e no envolvimento das proteínas no desenvolvimento de resistência tumoral ao tratamento radio e quimioterápico. Consequentemente, diversos outros estudos também focam no potencial prognóstico e preditivo da avaliação de expressão gênica e/ou proteica das MTs. Os resultados de diversos estudos indicam que o papel da expressão das MTs nas células tumorais pode estar ligado aos processos de morte celular por apoptose e proliferação celular, entretanto, outros estudos também indicam que as MTs são importantes no desenvolvimento da massa tumoral por outros meios, como participação na angiogênese e promovendo resistência à terapêutica oncológica. 


\subsubsection{Efeitos anti-apoptóticos}

Numerosos estudos in vitro e in vivo tem demonstrado a participação das MTs 1 e 2 (MT1/2) nos eventos de apoptose, embora as possibilidades de mecanismos sejam amplas e assim pouco esclarecidas. Muitos estudos focam no papel da MT como reguladora de apoptose por meio de interação com a p53 (Shimoda et al., 2003). A hipótese é que a p53 possui um domínio ligante de ADN que é estabilizado por um íon de Zn, o qual é necessário para uma configuração funcional ativa da p53 nativa. A MT neste caso pode agir quelando o $\mathrm{Zn}$ da p53, o que leva ao rompimento da arquitetura no domínio ligante de $A D N$ da p53, induzindo a adoção de um fenótipo imunológico inativo da p53 (Rainwater, 1995; Butler; Loh, 2003). Células tumorais desprovidas do gene da MT são significativamente mais sensitivas ao estímulo apoptótico, possuindo uma quantia três a quatro vezes maiores de p53 funcional do que as células in natura (Kondo et al., 1997). Tal fato pode significar um mecanismo epigenético de desregulação da p53, sabendo-se que nem todos os tumores demonstram mutação no gene TP53 (Butler; Loh, 2003).

A MT também pode interferir por mecanismos não esclarecidos inibindo a atividade de proteínas pró-apoptóticas como a caspase-1, caspase 3, e inibir escape do citocromo c (Miles et al., 2000; Penkowa, 2006; Pedersen; Larsen, 2009). Uma redução significante da ativação de caspase-3, inibição de escape do citocromo $\mathrm{c}$ e clivagem do $\mathrm{ADN}$ ocorrem em camundongos transgênicos com aumento de expressão de MT1 em comparação aos selvagens (Cai et al., 2006; Yang et al., 2006; Ren et al., 2008). E em contraste, camundongos knockout mostram vulnerabilidade aumentada como demonstrado pelos níveis aumentados de caspase-3 ativada, escape de citocromo c, clivagem de ADN e alterações morfológicas seguidas de injúria (Penkowa, 2006). Esta relação com a caspase-3 acontece possivelmente pelo fato de que o $\mathrm{Zn}$ também é fundamental para a atividade da mesma (Perry et al., 1997; Chimienti et al., 2001).

Alterações complementares entre MT e Bcl-2 e o oncogêne c-myc também foram propostas. Estudos tem demostrado que a inibição de MT2 resulta em uma queda dose-dependente de Bcl-2 e c-myc, seguindo-se para um aumento na taxa de apoptose em carcinomas de próstata e ovário, sugerindo que os efeitos anti- 
apoptóticos e favoráveis à sobrevivência celular mediados pela MT se deve em parte pela regulação de Bcl-2 e c-myc (Tekur; Ho, 2002; Theocharis et al., 2004).

\subsubsection{Proliferação celular}

Estudos indicam que a MT pode ativar várias metalo-enzimas e fatores de transcrição requeridos para regeneração celular e reparo tecidual, como por exemplo: aconitase, aldolase, fosfatase alcalina, anidrase carbônica, colagenase, sorbitol desidrogenase, termolisina, receptores de estrógeno, Gal4, Sp1, TFIIIA (Posewitz; Wilcox, 1995; Jiang et al., 1998; Maret et al., 1999; Huang et al., 2004; Cherian; Kang, 2006). Foi demonstrado que micro-injeção de apo-MT em células hepáticas vivas mostrou que a MT é capaz de remover o $\mathrm{Zn}$ das proteínas com dedos de Zn ligadas ao ADN, de Sp1 e do fator de transcrição IIIA (Zeng et al., 1991a,b). Suporta as hipóteses da MT como promotora de proliferação, o fato de que terapia com oligonucleotídeos específicos contra o gene da MT causa crescimento celular arrastado e induz apoptose em células ductais de carcinoma mamário (Abdel-mageed; Agrawal, 1997). Por outro lado, em células de carcinoma gástrico, o efeito é inverso, onde a inserção de MT2A por meio de vetor de plasmídeo induz atividade supressora de tumor, provavelmente pela inibição de ativadores de NF-KB (Pan et al., 2013). Porém, seguindo em controvérsias, em células HeLa a atividade de MT2A parece impedir a atividade inibitória do Zn sobre o NF-KB por meio de quelação (Kim et al., 2003). Desta forma, o papel das MTs na proliferação celular, seja como causador de alterações seja como responsivo às alterações de outras vias, parece ser variável segundo o tipo de tecido analisado.

Considera-se que a MT seja uma proteína citoplasmática em tecidos adultos ou células em repouso (G0), enquanto sua localização nuclear é tipicamente detectada em células no período fetal/neonatal (Chan; Cherian, 1993; Cherian et al., 2003). A translocação de MT para o compartimento nuclear tem sido observado de maneira que durante a fase $\mathrm{G} 0$ e a fase $\mathrm{G} 1$, detecta-se a MT situada principalmente no citoplasma, enquanto durante a fase $\mathrm{S}$ e a $\mathrm{G} 2$, sua expressão nuclear torna-se distinguível (Miles et al., 2000; Coyle et al., 2002; Sato e Konkoh, 2002; Theocharis 
et al., 2004; Cherian Kang, 2006). Outrora, ao final de G2 e início de M, a MT tende a retornar ao compartimento citoplasmático (Coyle et al., 2002b; Sato e Konkoh, 2002). Muitos estudos já mostraram uma correlação positiva entre a expressão de MT1/2 e antígenos de proliferação celular como o Ki-67, PCNA e Mcm-2. Tal relação foi demonstrada em tumores de tecidos diversos, como carcinomas de trato respiratório superior, de pulmões e de mama (Jayasurya et al., 2000; Park et al., 2011; Werynska et al., 2013b). Entretanto, os resultados nem sempre seguem este parâmetro, sendo que estudos com carcinoma epidermoide, carcinomas colorretais e carcinomas de tireoide, por exemplo, falharam em demonstrar correlação entre as MTs 1 e 2 com marcadores com o Ki-67 (Cardoso et al., 2002; Szelachowska et al., 2009). Uma correlação entre a expressão de Ki-67 e expressão do gene MT2A foi relatada por Jin e colaboradores (2002) estudando tumores de mama (Jin et al., 2002). Talvez a avaliação gênica seja o caminho para ratificar ou desmistificar a correlação entre as MTs e o Ki-67, ou talvez esta relação exista apenas para os tecidos onde as MTs tem maior participação em eventos de proliferação celular, que pode não ser o caso de determinados tumores.

\subsubsection{Angiogênese}

A angiogênese é um processo formado por várias etapas, envolvendo a degradação da membrana endotelial e da matriz tissular, a migração das células endoteliais e brotamento capilar (Valko et al., 2006). A presença de vasos sanguíneos é fundamental para o suprimento celular em tecidos normais e também para que ocorra desenvolvimento tumoral, sendo mais frequente em tumores malignos, principalmente aqueles que metastatisaram (Brahimi-Horn et al., 2007; Cardoso et al., 2009). O aumento de MT tem sido implicado ao aumento na síntese de novo e expressões aumentadas de numerosos fatores de crescimento implicados no processo angiogênico, incluindo FGF, TGFb, e VEGF (Penkowa, 2006; Nielsen et al., 2007). Em animais knockout para MT1/2 foi demonstrado decréscimo significativo da expressão de fatores angiogênicos após injúria cerebral, enquanto um número aumentado de capilares é observado em camundongos normais. Corrobora com a ação angiogênica o fato de que o efeito pró-angiogênico da IL-6 
também é atenuado pela ausência das MTs 1 e 2 (Penkowa et al., 2000). Miyashita e Sato (2005) mostraram que a inibição de MT1 em células endoteliais $n$ vitro prejudica a proliferação, migração, e formação de rede vascular, além de paralisar o ciclo celular em fase G1 (Miyashita; Sato, 2005).

\subsubsection{Resistência à terapêutica oncológica}

O papel da MT na resistência à cisplatina é frequentemente visto para tumores de ovário, onde pacientes com aumento de MT1/2 anteriormente à iniciação da quimioterapia, mostraram resposta inadequada ao tratamento e altas taxas de mortalidade (Surowiak et al., 2005). Adicionalmente, o aumento da expressão de MT em tumores de bexiga, esôfago, fígado e língua também resultaram em aumento da resistência à cisplatina (Theocharis et al., 2004). Outro ponto interessante, é que os estudos demonstram que a localização subcelular nas células tumorais é importante para a resistência tumoral ao tratamento, pois as células expostas à cisplatina tipicamente mostram uma expressão nuclear ao invés de citoplasmática, sugerindo a participação da MT na proteção do ADN (Kondo et al., 1997; Theocharis et al., 2004; Surowiak et al., 2005). Tal evento enfatiza a importância da avaliação do compartimento subcelular de marcação da MT para investigar o valor preditivo e prognóstico da MT nos diversos tumores. A ligação daquela com a molécula da droga ocorre na proporção de 1:10 e ocasiona a degradação direta da forma ativa do oncoterápico, dado que os radicais amina são perdidos no processo. Ainda pela interação entre as duas moléculas, a liberação de átomos que estavam ligados à metalotioneína, geralmente zinco, pode contribuir para a melhora da eficiência de enzimas de reparo genômico (Chu, 1994). Além disto, uma indução de expressão dos genes de MT1/2 pela cisplatina já foi relatada em linhagens resistentes de carcinoma epidermoide bucal (Nakano et al., 2003).

Considerando a radioterapia, ressalta-se que a radiação causa dano genômico à célula por duas vias. A primeira via seria induzida por energia de alta intensidade e seria responsável por cerca de $10 \%$ das lesões genômicas provocadas pela radiação. $\mathrm{Na}$ segunda via, dada por radiações de baixa 
intensidade, ocorre absorção direta da energia em ligações $\mathrm{C}-\mathrm{H}$ e sua consequente quebra, liberando então radicais de carbono que podem rapidamente reagir com moléculas de oxigênio e formar peróxidos e radicais de oxigênio, os quais podem então causar genotoxicidade. As MTs, dado seu alto conteúdo de cisteína, ligar-seiam a estes compostos nucleófilos tóxicos, liberando átomos de zinco que por sua vez poderiam se associar a enzimas de reparo de $A D N$, contribuindo para a redução do dano (Cai et al., 1999). Observa-se um aumento de expressão gênica das MTs, principalmente à custa de MT2A em células de carcinoma retal após radioterapia, mas não uma maior expressão proteica in vivo comparando os tecidos de antes e após tratamento radioterápico.

\subsubsection{Expressão da MT em neoplasias e tecidos não neoplásicos correspondentes}

As possibilidades de participação das MTs nos processo neoplásicos são múltiplas e complexas, haja vista sua complexidade de regulação gênica e sua capacidade de interagir em diversos processos biológicos, como pode ser visto nos capítulos anteriores. Diversos estudos avaliaram a expressão das MTs em comparação com fatores críticos do comportamento tumoral, como grau de crescimento, grau de diferenciação, comportamento metastático, sobrevida dos pacientes, resistência terapêutica tumoral, dentre outros. Os resultados obtidos são promissores e ao mesmo tempo controversos, pois o padrão de expressão das MTs nas neoplasias é muito variável, relacionando-se diretamente com variações na origem tecidual, tipo de tumor, estágio de diferenciação e comportamento metastático. A revisão subsequente discutirá tumores de órgãos diversos, ressaltando as principais evidências que apontam as MTs como alvo do entendimento do desenvolvimento e progressão tumoral, bem como alvo de pesquisas sobre a terapêutica tumoral. A tabela 2.3 sumariza a significância da expressão proteica de MT1/2 nas variadas neoplasias em humanos. 
Tabela 2.3 - Sumário do papel da família das metalotioneínas enquanto marcadoras de agressividade e progressão para tumores de órgãos diversos

\begin{tabular}{|c|c|c|c|c|c|}
\hline \multirow{3}{*}{ Origem tumoral } & \multicolumn{5}{|c|}{ Expressão de Metalotioneína na transformação neoplásica } \\
\hline & \multirow{2}{*}{ Expressão proteica de MT1/2 } & \multicolumn{3}{|c|}{ Expressão gênica tumoral } & \multirow{2}{*}{ Correlação com prognóstico } \\
\hline & & Aumento & S/alteração & Redução & \\
\hline Mucosa oral & $\begin{array}{l}\text { ○ Aumentada } \\
\text { - C. camada basal e parabasal }\end{array}$ & NA & NA & NA & $\begin{array}{l}\text { - } \uparrow \mathrm{MT} 1 / 2 \text { com queda sobrevida e aumento de } \\
\text { metástase linfonodal. }\end{array}$ \\
\hline Nasofaringe/ Laringe & $\begin{array}{l}\text { - Aumentada } \\
\text { - C. camada basal }\end{array}$ & $M T 2 A^{(\#)}$ & - & $M T 1 E^{(\#)}$ & - $M T 1 / 2$ com estágio clínico avançado. \\
\hline Esôfago & $\begin{array}{l}\text { ○ Aumentada } \\
\text { - Topografia não esclarecida }\end{array}$ & NA & NA & NA & $\begin{array}{l}\text { - } \text { ARNm e proteína de } \mathrm{MT} 1 / 2 \text { com pior estágio } \\
\text { clínico, metástase regional e à distância, pior } \\
\text { sobrevida e resistência à cisplatina. }\end{array}$ \\
\hline Estômago & $\begin{array}{l}\text { ○ Diminuída }{ }^{(\#)} \\
\text { - C. Epiteliais (fossetas gástricas) }\end{array}$ & - & MT1E,$-1 F \mathrm{e}-1 G^{(\#)}$ & MT2A, $-3^{(\#)}$ & $\begin{array}{l}\text { - } \uparrow \text { MT } 1 / 2 \text { com metastáticos e pior sobrevida (estudo } \\
\text { controverso). }\end{array}$ \\
\hline Mucosa colorretal & $\begin{array}{l}\text { - Diminuída } \\
\text { - Enterócitos }\end{array}$ & - & $M T 1 X,-2 A$ & $\begin{array}{c}\text { MT1A, }-1 E,-1 F,-1 G, e \\
1 H\end{array}$ & - $\downarrow$ MT1/2 com menor diferenciação. \\
\hline Glândulas Salivares & $\begin{array}{l}\text { ○ Aumentada } \\
\text { - C. mioepiteliais e basais }\end{array}$ & NA & NA & NA & $\begin{array}{l}\text { - } \mathrm{N} M T 1 / 2 \text { com casos de CAC de metástase precoce e } \\
\text { menor diferenciação. }\end{array}$ \\
\hline Mama & $\begin{array}{l}\text { ○ Aumentada } \\
\text { - C. mioepiteliais e basais }\end{array}$ & $M T 1 E,-2 A, 3$ & - & $M T 1 F,-1 G$ & $\begin{array}{l}\text { - } \uparrow \text { MT1/2 com menor grau histológico e nuclear; } \\
\text { estágio clínico avançado, metástase linfonodal, pior } \\
\text { prognóstico; } \\
\text { - } M \text { MT2A com menor diferenciação; } \\
-\uparrow \text { MT1E com casos RE-negativos; } \\
-\downarrow \text { MT3 indica maior sobrevida. }\end{array}$ \\
\hline Tireoide & $\begin{array}{l}\text { - Diminuída }{ }^{(\#)} \\
\text { - C. foliculares }\end{array}$ & - & - & $M T 1 E,-1 G,-1 X,-2 A$ & \\
\hline Testículos & $\begin{array}{l}\text { ○ Variável } \\
\text { - Não esclarecido }\end{array}$ & NA & NA & NA & $\begin{array}{l}\text { - } \uparrow M T 1 / 2 \text { pode predizer melhor resposta à } \\
\text { quimioterapia. }\end{array}$ \\
\hline Próstata & $\begin{array}{l}\text { - Diminuída } \\
\text { - Epitélio glandular }\end{array}$ & MT3 & $M T 1 F$ e $-2 A$ & $M T 1 A,-1 E,-1 G$ e $-1 X$ & $\begin{array}{l}\text { - } \downarrow \text { MT1/2 com menor diferenciação; } \\
\text { - } \text { metilação de } M T 1 G \text { em casos de pior estágio } \\
\text { clínico. }\end{array}$ \\
\hline Fígado & $\begin{array}{l}\text { - Diminuída } \\
\text { - Hepatócitos }\end{array}$ & - & - & $\begin{array}{c}\text { MT1A, }-1 B,-1 E,-1 F,-1 G \\
-1 H,-3 \mathrm{e}-4\end{array}$ & $\begin{array}{l}\text { - } \downarrow \mathrm{MT} 1 / 2 \text { com aumento do grau histológico, estágio e } \\
\text { tamanho tumoral; } \\
\text { - } \text { MT1/2 com resistência à quimioterapia. }\end{array}$ \\
\hline Rins & $\begin{array}{l}\text { - Diminuída } \\
\text { - Túbulos proximais }\end{array}$ & MT2A & MT1E, $-1 F \mathrm{e}-1 X$ & $M T 1 A,-1 G$ & - $\uparrow$ MT1/2 com menor diferenciação \\
\hline Bexiga & $\begin{array}{l}\text { - Aumentada } \\
\text { - Ausente }\end{array}$ & $M T 1 X$ e -3 & MT2A & - & $\begin{array}{l}\text { - } \text { N MT1/2 com aumento do grau histológico e estágio } \\
\text { clínico, pior prognóstico; } \\
\text { - Expressão proteica de MT3 com pior grau histológico. }\end{array}$ \\
\hline Pulmões & $\begin{array}{l}\text { - Aumentada } \\
\text { - Pneumócitos }\end{array}$ & $\begin{array}{l}M T 1 B,-1 F,-1 G,- \\
1 H,-1 X \mathrm{e}-3\end{array}$ & $M T 1 A$ e $-2 A$ & MT1E & $\begin{array}{l}-\uparrow M T 1 F \text { em tumores menos diferenciados e MT1Fe } \\
\text { MT2A em casos de pior sobrevida; } \\
\text { - } \downarrow M T 3 \text { indica pior sobrevida }\end{array}$ \\
\hline
\end{tabular}




\subsubsection{Metalotioneína em mucosa oral e carcinoma epidermoide bucal}

Em mucosa não-neoplásica, os autores geralmente relatam um padrão de marcação de MT1/2 em camada basal e parabasal (Sundelin et al., 1997). No estudo conduzido por Katsuragi e colaboradores (1997) com 33 espécimes de pacientes portadores de doença periodontal sem histórico de carcinoma epidermoide bucal (CEB), foi observado um padrão descontínuo de marcação nos pacientes não tabagistas, envolvendo camada basal com extensão variável para camada espinhosa. A frequência de células positivas e a intensidade de marcação observada em tecido periodontal de pacientes tabagistas foi significativamente maior (Katsuragi et al., 1997). O primeiro estudo que avaliou a expressão das MTs em CEB foi realizado por Sundelin e colaboradores também em 1997. Os autores avaliaram a expressão proteica de MT1/2 em 24 carcinomas epidermoides bem diferenciados de língua, destacando como achado uma marcação de MT intensa na camada basal do epitélio de revestimento normal e uma marcação restrita às células periféricas das ilhotas tumorais bem diferenciadas (Sundelin et al., 1997). Posteriormente, outro estudo observou padrão semelhante a este, com marcação em núcleo e citoplasma celular, destacando uma marcação em padrão de mosaico, onde células intensamente marcadas alternavam com células negativas nos tumores (Muramatsu et al., 2000). Neste trabalho os autores ainda demonstraram que os tumores pobremente diferenciados recebem os maiores índices de expressão em imunohistoquímica (Muramatsu et al., 2000). Da mesma forma, foi demonstrado que a expressão da MT está aumentada em tecido epitelial com displasia, sugerindo assim uma participação da MT no processo de carcinogênese (Johann et al., 2008; Pontes et al., 2009).

Sundelin e colaboradores (1997) sugeriram a partir de seu estudo, que a disposição de MT em camada basal de epitélio e perifericamente às ilhotas tumorais, seria sugestiva de que a MT pode exercer papel inibitório da apoptose, corroborando com esta hipótese a uma positividade ao centro das ilhotas tumorais para a técnica TUNEL (Sundelin et al., 1997). No estudo de Pontes e colaboradores (2009) os autores observaram que nos tumores sem 
formação de pérola córnea, a MT expressava-se até as camadas centrais das ilhotas, enquanto que nas pérolas córneas restringia-se à periferia (Pontes et al., 2009). Uma queda significante de sobrevida foi relatada para casos com índice de expressão de MT1/2 superiores a 76\%, representando um marcador independente de prognóstico, juntamente com o TNM avançado (Cardoso et al., 2002). Szelachowska e colaboradores (2008) demonstraram associação entre maior intensidade e proporção de células marcadas por anticorpo contra MT1/2 com pior sobrevida dos pacientes (Szelachowska et al., 2009). A marcação observada em queratínócitos normais e no CEB é do tipo nuclear e citoplasmática (Sundelin et al., 1997; Muramatsu et al., 2000; Cardoso et al., 2002; Johann et al., 2008). Entretanto, Szelachowska e colaboradores (2008) demonstraram que tumores expressando MT nuclear em mais de $50 \%$ das células positivas tiveram uma queda de sobrevida significante (Szelachowska et al., 2009). Cardoso e colaboradores (2009) observaram que a expressão nuclear de MT1/2 esteve correlacionada com a positividade para p53, e os dois marcadores quando demonstraram associação significante com queda de sobrevida (Cardoso et al., 2009). Desta forma, as MTs 1 e 2 parecem relacionar-se mais a eventos envolvidos com a inibição de apoptose do que com proliferação celular, visto que não há uma associação entre esta expressão e a de marcadores como Ki-67 e Mcm-2 (Cardoso et al., 2002; Szelachowska et al., 2009).

Zavras e colaboradores (2011) avaliaram polimorfismos relacionados aos genes de MT1 em 240 indivíduos com CEB e 347 controles, demonstrando que indivíduos portadores do alelo rs8052394 AA estão sob um risco significativamente maior para desenvolvimento de $C E B$, enquanto que indivíduos portadores dos alelos rs11076161 A, rs964372 C e rs7191779 C estão sob risco menor do que os demais, sugerindo ser este um genótipo protetor (Zavras et al., 2011). Além disto, as MTs podem ter um papel na resistência de casos de CEB à cisplatina. Em um estudo in vitro avaliando a resistência de células de CEB à cisplatina, um quimioterápico frequentemente utilizado no tratamento oncológico, Nakano e colaboradores (2003) observaram uma indução de expressão dos genes de MT1/2 apenas nas linhagens resistentes. Estes achados demonstram que 0 tratamento quimioterápico pode induzir a expressão de MTs e este processo pode ser 
preditivo de CEBs com resistência à terapêutica com a Cisplatina (Nakano et al., 2003)

Uma isoforma que parece peculiar de epitélios estratificados é a MT4. A hibridização in situ revela que o ARNm que codifica MT4 destaca-se em camada espinhosa e córnea da mucosa oral, enquanto que a imunoexpressão de MT1/2 se restringe principalmente à camada basal. Assim, sugere-se haver uma mudança na síntese das isoformas das MTs durante a diferenciação epitelial (Quaife et al., 1994).

Em três estudos, uma correlação positiva foi observada entre a intensidade de expressão de MT1/2 e o envolvimento linfonodal do CEB (Lee et al., 2008; Szelachowska et al., 2008; Szelachowska et al., 2009). Desta forma, as MTs parecem importantes no processo de desenvolvimento e progressão do CEB. Embora os resultados dos estudos clínicos mostrem limitações de tamanho amostral e heterogeneidade de coorte, existem evidências que o estudo de sua expressão possa fornecer informações sobre o comportamento metastático do CEB e sobrevida. Estudos que avaliam a expressão gênica específica das isoformas das MTs fornecem informações adicionais sobre o comportamento biológico destas lesões. Ainda não há informações sobre esta expressão específica no CEB. A tabela 2.4 sumariza os principais achados dos estudos sobre a expressão de MTs e o comportamento do CEB. 
Tabela 2.4 - Sumário de resultados dos estudos que avaliaram a expressão de Metalotioneína em carcinoma epidermoide bucal

\begin{tabular}{|c|c|c|c|c|c|c|}
\hline & \multicolumn{6}{|c|}{ Expressão proteica de MT1/2* em CEB } \\
\hline & $\begin{array}{l}\text { Muramatsu } \\
\text { et al., } 2000\end{array}$ & $\begin{array}{l}\text { Cardoso } \\
\text { et al., } \\
2002\end{array}$ & $\begin{array}{l}\text { Lee et al., } \\
2008\end{array}$ & $\begin{array}{l}\text { Szelachowska } \\
\text { et al., } 2008\end{array}$ & $\begin{array}{l}\text { Szelachowska et } \\
\text { al., } 2009\end{array}$ & $\begin{array}{l}\text { Cardoso et } \\
\text { al., } 2009\end{array}$ \\
\hline $\begin{array}{l}\text { No. } \\
\text { Pacientes }\end{array}$ & 28 & 60 & 34 & 50 & 39 & 100 \\
\hline $\begin{array}{l}\text { Expressão } \\
\text { proteica }\end{array}$ & MT1/2 & MT1/2 & MT1 & MT1/2 & MT1/2 & MT1/2 \\
\hline pT & - & - & - & - & - & NA \\
\hline $\mathrm{pN}$ & - & - & + & $\stackrel{+}{+}$ & + & NA \\
\hline $\begin{array}{l}\text { Grau } \\
\text { histológico }\end{array}$ & NA & - & - & - & - & - \\
\hline Sobrevida & NA & + & NA & + & NA & + \\
\hline $\begin{array}{l}\text { Proliferação } \\
\text { celular }\end{array}$ & - (Ki-67) & - (Ki-67) & NA & $\begin{array}{c}-(\mathrm{Ki}-67) \\
-(\mathrm{MCM}-2)\end{array}$ & $\begin{array}{c}-(\mathrm{Ki}-67) \\
-(\mathrm{MCM}-2)\end{array}$ & - \\
\hline $\begin{array}{l}\text { Outros } \\
\text { marcadores }\end{array}$ & NA & NA & NA & NA & + Laminina-5 & $+(p 53)$ \\
\hline Notas & $\begin{array}{l}\text { Incluiu } \\
\text { casos de } \\
\text { CEB e } \\
\text { carcinoma } \\
\text { de laringe }\end{array}$ & & $\begin{array}{l}\text { Usuários } \\
\text { de areca } \\
\text { quid }\end{array}$ & $\begin{array}{c}\text { Menor } \\
\text { sobrevida para } \\
\text { casos com alta } \\
\text { expressão de } \\
\text { MT1/2 }\end{array}$ & & $\begin{array}{c}\text { Menor } \\
\text { sobrevida } \\
\text { em alta } \\
\text { expressão } \\
\text { simultânea } \\
\text { de MT1/2 e } \\
\text { p53 }\end{array}$ \\
\hline
\end{tabular}

* CEB: carcinoma epidermoide bucal. MT1/2: Isoformas proteicas metalotioneína 1 e metalotioneína 2. (-) indica ausência de associação e (+) indica associação. significativa. NA: não avaliado.

\subsubsection{Expressão da metalotioneína em outros tecidos}

\subsubsection{Nasofaringe/Laringe}

No epitélio normal da nasofaringe ocorre expressão de MT1/2 na camada basal do epitélio. Em tumores, há uma correlação significativa entre a positividade de MT1/2 e o índice de proliferação Ki-67, além de uma relação com a maior disponibilidade de Zn nuclear, o que sugere que a MT1/2 possa aumentar o Zn intranuclear e assim permitir aumento de multiplicação (Jayasurya et al., 2000). Um estudo publicado em literatura chinesa mostrou 
decréscimo significante de MT após a radioterapia (Su et al., 2003). Nos carcinomas laríngeos, existe um aumento significante de transcrição de MT1/2 em comparação com o tecido normal, inclusive para aquelas lesões em estágios precoces de transformação. Entretanto a MT não foi capaz de determinar prognóstico dentre as malignidades analisadas (Pastuszewski et al., 2007). Com relação à expressão gênica, avaliando $M T 2 A$ e $M T 1 E$ em estudo in vitro, observa-se uma expressão generalizada de MT2A, enquanto que MT1E foi observada apenas nas células HK1, que são bem diferenciadas, e nas células TW01, que são moderadamente diferenciadas, mas não nas células CNE2, que são pobremente diferenciadas. A terapia anti-MT2A nas células CNE2 resultou em redução da viabilidade celular e proliferação, o que pode indicar uma futura opção terapêutica (Tan et al., 2005).

\subsubsection{Esôfago}

A expressão de MT está envolvida com a progressão histológica "metaplasia-displasia-adenocarcinoma" de esôfago (Dutsch-Wicherek et al., 2008). Um aumento da expressão proteica de MT1/2 foi relatado para os carcinomas de esôfago em estágios avançados (Hishikawa et al., 1997). Em outro estudo, onde os autores elaboraram uma sonda genérica para detecção do $A R N m$ de todas as isoformas da $M T$, foi demonstrada uma relação entre casos de ARNm positivo e maior frequência de metástases linfonodais e à distância, da mesma forma como também foi observado para a expressão proteica de MT1/2 (Hishikawa et al., 1999). Os autores ainda observaram associação da expressão das MT1/2 com maior expressão de PCNA, indicando associação com a proliferação celular (Hishikawa et al., 1999). Outro estudo indica que a isoforma MT3 esteve aumentada nos tumores em relação ao tecido normal, associando-se ainda ao grau de diferenciação, metástase linfonodal e sobrevida, mas não se correlacionou com a expressão de MT1/2 (Tian et al., 2008). Mais recentemente, foi observado que a transfecção de MT3 para células malignas de origem esofágica resulta em 
redução de atividade proliferativa e indução de apoptose nas células. Nenhuma alteração foi observada quando feito o experimento com transfecção de MT1E (Tian et al., 2013).

Alguns trabalhos demonstram associação da MT com o esôfago de Barret, que é uma metaplasia colunar do epitélio esofágico em substituição ao epitélio normal, causada por injúria crônica da mucosa esofágica pelo suco gástrico em indivíduos com gastrite (Coyle et al., 2002a; Li et al., 2003). Um dos trabalhos destaca que o aumento das MTs ocorre somente nas porções de transição da metaplasia para o adenocarcinoma (Coyle et al., 2002a).

\subsubsection{Estômago}

A mucosa gástrica geralmente expressa MT em células epiteliais do antro e corpo de forma difusa e em regiões das fossetas ou fóveas gástricas, que são regiões de alta atividade proliferativa, e em glândulas secretoras de ácido (Ebert et al., 2000; Janssen et al., 2000; Tuccari et al., 2000; Mitani et al., 2008). Desta forma, ressalta-se que a mucosa gástrica não é constituída por uma população celular monótona, existindo regiões que são frequentemente positivas para MT e outras que são negativas. Janssen e colaboradores (2002), por exemplo, demonstraram através de radioimunoensaio quantidade significativamente menor de MT no antro do que nas demais regiões estomacais (Janssen et al., 2002). A expressão de MT nos carcinomas gástricos tem sido controversa, pois alguns estudos mostram MT reduzida nos carcinomas gástricos em relação ao tecido normal, e outros mostraram resultado inverso. Um estudo evidenciou por imunohistoquímica que mais de $60 \%$ das células expressavam MT1/2 em casos classificados com TNM avançado, casos com presença de metástases nodais (mais elevada ainda em múltiplas metástases nodais, e maiores que 2 $\mathrm{cm}$ ), e metástases à distância. Os autores ainda demonstraram sobrevida significativamente menor que para casos de marcação forte para MT, e expressão inversamente proporcional à de p27, uma proteína envolvida com apoptose e responsável por manter a célula em repouso (G0) (Galizia et al., 
2006). Outro marcador envolvido na proliferação celular, o PCNA, também esteve correlacionado à expressão de MT em uma série de carcinomas gástricos, indicando relação de MT com o ciclo celular (Monden et al., 1997). No estudo de Ebert e colaboradores (2000) o gene MT2A foi avaliado em dois casos e esteve mais expresso em relação à mucosa normal. Os autores ainda mostraram que MT1A e MT3 não foram detectados em PCR convencional na maioria dos casos de pacientes sem carcinoma gástrico, enquanto que foram encontrados com maior frequência nos carcinomas gástricos e ainda na mucosa gástrica normal dos parentes de primeiro grau destes pacientes, demonstrando que a expressão destes genes pode ser indicador de susceptibilidade ao desenvolvimento neoplásico na mucosa estomacal (Ebert et al., 2000). Resultado semelhante foi observado por Janssen e colaboradores (2002) em estudo avaliando a expressão proteica do conjunto das MTs por meio de radioimunoensaio. Neste estudo os autores encontraram maior expressão das MTs na mucosa normal dos pacientes com pior prognóstico, mas não observaram esta diferença de expressão nos tumores. Por outro lado, eles relataram que houve menor expressão nos carcinomas gástricos em relação ao tecido normal (Janssen et al., 2002). Tuccari e colaboradores (2000) também afirmam que os casos de carcinoma gástrico mostram queda de expressão de MT1/2 em relação à mucosa normal, sem associação com os dados clinico-patológicos (Tuccari et al., 2000). No estudo mais recente de avaliação das MTs nos carcinomas e tecidos gástricos não-neoplásicos, Pan e colaboradores (2013) demonstraram um decréscimo gradual significativo em quantidade de casos com expressão de MT1/2 partindo de uma mucosa normal para metaplasia intestinal e com queda maior para carcinoma gástrico. Os autores também identificaram que o MT2A está altamente expresso nas células benignas GES1 e tecidos normais, mas encontra-se reduzido ou ausente na maioria das células malignas em cultura e tecidos de carcinoma gástrico. Não houve diferença na expressão de MT1E, MT1F e MT1G comparando amostras de tecido normal com amostras tumorais. Por fim, os autores demonstraram que uma expressão ectópica de MT2A após inserção por vetor de plasmídio esteve relacionada com prejuízo de faze G2/M nas células de carcinoma gástrico (Pan et al., 2013). 
Um trabalho avaliando o ADN complementar (ADNc) de amostras de carcinoma gástrico por ADNc array demonstrou uma queda de significante (10x) de expressão de MT3 (El-Rifai et al., 2001). Posteriormente, os autores demonstraram em outro trabalho que a presença de uma metilação aberrante no íntron 1 da região promotora de MT3 pode ser a causa desta queda ou ausência de expressão (Deng et al., 2003).

\subsubsection{Mucosa colorretal}

Em mucosa colorretal aparentemente normal, a MT está predominantemente localizada nos enterócitos (citoplasma e núcleo das células apicais maduras), sendo que na lâmina própria, as células globosas e as células profundas nas criptas permanecem MT-negativas (Giuffrè et al., 1996; Janssen et al., 2000). No geral, as mucosas normais tendem a apresentar mais MT do que nos carcinomas e nos adenomas (Arriaga et al., 2012; Janssen et al., 2002). Em apenas um estudo relatou-se aumento de MT na mucosa normal e nos tumores associados correlacionando-se com menor sobrevida dos pacientes. Pra mucosa normal, níveis acima de $163 \mathrm{ng} / \mathrm{mg}$ de MT determinou sobrevida, enquanto para os tumores, o pior prognóstico reservou-se a casos com mais de $315 \mathrm{ng} / \mathrm{mg}$ de MT (Janssen et al., 2002). Entretanto, outros estudos mostram que a queda de expressão das MTs é que indica desenvolvimento e progressão tumoral. Uma expressão aumentada de MT1/2 simultaneamente com expressão negativa de p53 foi associada a menor profundidade dos tumores, menor incidência de metástase e aumento de sobrevida. No entanto, neste estudo a expressão de MT1/2 isolada não esteve correlacionada a nenhum outro fator clínico-patológico (Arriaga et al., 2012). Ofner e colegas relataram que a expressão negativa de MT em carcinomas colorretais correlaciona-se com alto estágio tumoral e com comprometimento linfonodal, enquanto a positividade de MT determina prognóstico favorável (Ofner et al., 1994). Outro trabalho mostrou resultados semelhantes, com menor expressão de MT1/2 em carcinomas avançados, porém não houve associação com sobrevida ou outros dados clínicopatológicos. Neste trabalho, os autores também quantificaram a mucosa de 
transição para o carcinoma, e concluíram que há uma queda de expressão no tecido tumoral em relação à mucosa não neoplásica (Tuccari et al., 2000).

Arriaga e colaboradores (2012) avaliaram a expressão gênica e proteica de MT1/2 de 22 casos de adenocarcinomas colorretais. Os autores observaram que MT1E, MT1M, MT1X e MT2A foram os genes mais expressos no epitélio tumoral, enquanto que os níveis de expressão de MT1A, MT1F, MT1G, e MT1H foram significativamente menores. Na mucosa normal, eles observaram que apenas a isoforma MT1E encontra-se significativamente mais expressa do que as demais. Avaliando a transição entre mucosa e tumor, os autores observaram uma queda de expressão em $57 \%$ a $91 \%$ dos casos, a depender do gene avaliado. Os genes MT1E, MT1G e MT1F foram significativamente suprimidos durante esta transição. Os autores demonstraram que a queda de expressão de MT1G está associada com hipermetilação em sua região promotora, observando ainda que o tratamento com um inibidor de metil transferase em células HCT-116 e HT-29 restaura a expressão de $M T 1 G$ em 750 vezes. Uma correlação com queda de expressão proteica de MT1/2 foi obtida para as isoformas MT2A e MT1X (Arriaga et al., 2012).

\subsubsection{Glândulas Salivares}

De maneira semelhante ao visto para glândulas mamárias, as glândulas salivares normais somente expressam naturalmente MT nas células mioepiteliais e nas células basais dos ductos excretores (Sunardhi-

Widyaputra et al., 1995; Muramatsu et al., 2000; Brazão-Silva et al., 2013). Um trabalho inicial avaliou a marcação de MT em tumores benignos e no carcinoma mucoepidermoide (Sunardhi-Widyaputra et al., 1995). Nos Adenomas pleomórficos (AP) e no tumor de Warthin (TW), uma marcação na camada externa das estruturas ductais foi encontrada. No AP a MT1/2 também destacou algumas células embebidas em estroma mixoide e condroide. As áreas de padrão trabecular também mostraram forte marcação, 
enquanto o tecido adjacente era negativo. Já no TW, apenas mais algumas células ductais marcaram fracamente com MT, sendo os componentes linfoides desprovidos de marcação. A positividade para MT também foi observada em células cuboidais que margeavam ilhotas oncocíticas dos oncocitomas e células que margeavam grupos de células tumorais do carcinoma mucoepidermoide. Os autores mencionam alta marcação de MT somente nos mioepiteliomas. Tais resultados estão de acordo com o esperado, enquanto a MT1/2 tem sido vista preferencialmente em células mioepiteliais (Sunardhi-Widyaputra et al., 1995). Um estudo publicado em literatura chinesa também relatou maior expressão de MT1/2 nos mioepiteliomas e carcinomas mioepiteliais, porém não se tem informação sobre o anticorpo utilizado (Gao et al., 1997). Outros autores também relataram a presença de MT nas células mioepiteliais de adenomas pleomórficos, porém ressaltam a maior expressão desta em casos de Carcinoma Adenoide Cístico (CAC), principalmente em regiões proliferativas (Chauvin et al., 1992). Alves e colaboradores (2007) avaliaram a MT em CAC de glândulas salivares. Os autores demonstraram uma grande quantidade de células marcadas para todos os casos, com destaque para maior frequência em tumores do subtipo sólido, que são aqueles normalmente associados com prognóstico pior (Alves et al., 2007). Mais recentemente, Brazão-Silva e colaboradores (2013) avaliaram uma série de 49 casos de CAC, demonstrando por imunohistoquímica que o aumento de MT1/2 está associado ao comportamento metastático precoce da neoplasia (Brazão-Silva et al., 2013).

Irie e colaboradores estudaram a expressão de MT3 nas glândulas salivares, demonstrando um padrão de marcação é completamente diferente daquele visto para $M T 1 / 2$, onde as células ductais são intensamente marcadas e as células acinares em intensidade mais fraca (Irie et al., 2004). Os autores também avaliaram o NGF (Fator de crescimento dos neurônios), mostrando muitas vezes co-localização deste com MT3, o que implica concluir que a MT3 pode coordenar o crescimento e diferenciação das glândulas salivares, pois esta função é exercida pela mesma nos tecidos cerebrais (Irie et al., 2004). Novos estudos devem considerar a avaliação de MT3 para os tumores de glândulas salivares. 


\subsubsection{Glândulas mamárias}

Em tecidos normais, todos os trabalhos mostram forte expressão de MT em células mioepiteliais, o que estimulou diversos estudos propondo a MT como marcador específico para células mioepiteliais, enquanto que os elementos epiteliais, tais como ductos e ácinos, são MT negativos (Fresno et al., 1993; Bier et al., 1994; Yap et al., 2009). A expressão de MT por imunohistoquímica em carcinomas de mama tem sido bem documentada, mostrando uma relação predominante entre uma marcação forte e pior prognóstico. O fato da maior expressão da MT estar relacionado com tumores menos diferenciados, ou de pior grau histológico é quase unânime nos demasiados estudos (Fresno et al., 1993; Haerslev et al., 1995; loachim et al., 1999; Jin et al., 2001; Sharkawy; Farrag 2008a; Yap et al., 2009). Estes tumores ainda mostram maior expressão de MT nas regiões de pleomorfismo nuclear severo e maior quantidade de mitoses (Fresno et al., 1993; Haerslev et al., 1995; Zhang et al., 2000). Ocorre uma correlação positiva entre células MT positivas e de núcleo atípico com a expressão de Ki-67 (Oyama et al., 1996). Piores índices de sobrevida têm sido relatados para casos intensamente marcados pela MT (Haerslev et al., 1995). Desta forma, casos que recidivaram e casos metastáticos também marcam intensamente em comparação com os demais, confirmando a importância da MT durante o comportamento tumoral mais agressivo (Schmid et al., 1993; Haerslev et al., 1995). Outro estudo alerta para o fato de que diferenças com respeito ao tabagismo podem refletir em alterações das MTs nas neoplasias de mama, sendo que esta alteração foi mais significativa quando avaliada a expressão em tumores de baixo grau (Gallicchio et al., 2004).

Os estudos que avaliaram as isoformas gênicas específicas permitem afirmar que há uma expressão de MT1A, MT1E, MT1F, MT1G, MT1H, MT1X e $M T 2 A$ nos tecidos normais. A expressão de $M T 1 B$ não foi detectada nem em tumores nem em tecidos benignos, enquanto que MT3 somente foi expresso em tumores malignos de pior prognóstico (Jin et al., 2001; Sens et al., 2000; Tai et al., 2003). O MT2A é o gene que se expressa em maiores proporções nos tecidos benignos e nos tumores, correlacionando-se 
positivamente com a proliferação celular e grau histológico. Tumores com grau III histológico, possuem alta expressão do ARNm de $M T 2 A$, quando comparado ao grau 1 e 2 (Jin et al., 2002). O tratamento com RNA de interferência contra MT2A em células MCF-7 aumentou a quimiosensitividade das células à doxorrubicina, sendo que quantidade significativamente maior de células entrou em apoptose (Yap et al., 2009). Foi demonstrado ainda que o silenciamento de MT2A aumenta a ocorrência de morte por entose nas linhagens MCF-7 (Lai et al., 2010). Em outro trabalho foi identificado que a expressão de MT2A promove fenótipo invasivo de células MDA-MB-231 por meio de ativação de metaloproteínase de matrix 9 (MMP-9) via ativação de AP-1 e NF-kB. Além disso, os autores também silenciaram MT2A com RNA de interferência e observaram inibição do fenótipo invasivo das células (Kim et al., 2011). Desta forma, este conjunto de achados tem colocado o MT2A como alvo potencial de terapias contra o câncer de mama. Um estudo avaliou a presença de polimorfismos em uma população polonesa, encontrando um SNP no gene MT2A(rs28366003) que está associado ao risco de câncer de mama (Krześlak et al., 2012).

O gene MT1F está significativamente mais expresso nos tecidos benignos (células mioepiteliais) (Jin et al., 2002). Entretanto, já foi relatado em um trabalho que a expressão de MT1F pode estar aumentada segundo o grau histológico destas neoplasias (Jin et al., 2001). Outro trabalho mostra que não há diferenças em relação ao potencial invasivo de células em cultura com expressão de MT1F. Desta forma, os dados são controversos com relação ao potencial de avaliação de $M T 1 F$ como marcador de diferenciação ou prognóstico (Tai et al., 2003). Com relação aos genes MT1A e MT1G, observou-se em estudo de cultura de células uma ausência de expressão nas células comerciais malignas. Para MT1G, foi observada expressão em células mioepiteiliais e ausência nas células malignas de cultura (Tai et al., 2003). Um estudo de avaliação da presença de genes com metilação em amostras de glândula normal, carcinoma ductal in situ e carcinoma ductal invasivo aponta este evento em MT1G como um sinal de transição de tecido normal para malignidade. Além disto, estes autores observaram maior frequência desta metilação em correlação positiva com o grau histológico tumoral e aumento de expressão de ki-67 (Park et al., 2011). Com relação à isoforma MT1E, tem 
sido demonstrada uma associação entre o aumento de sua expressão e a marcação negativa para o receptor de estrógeno (RE) (Jin et al., 2000; Tai et al., 2003). Considerando que o RE já tem importância consolidada na avaliação do prognóstico para neoplasias de mama, esta associação sugere que a $M T 1 E$ possa ser um alvo para restabelecimento de RE ou um marcador de prognóstico associado (Tai et al, 2003; Sharkawy; Farrag, 2008). Em imunohistoquímica muitos trabalhos também procuraram avaliar a associação entre o RE e a MT, mostrando que os altos índices de MT correlacionam sempre com menor marcação de receptor de estrógeno, ou seja, com perda de diferenciação (Fresno et al., 1993; Oyama et al., 1996; loachim et al., 1999; Sharkawy; Farrag 2008).

O gene MT3 e sua proteína não estão expressos nas glândulas mamárias normais, sendo que uma ausência de sua marcação nos tumores está relacionada com maior sobrevida (Sens et al., 2001). Nos tecidos normais este gene parece estar silenciado por metilação da região promotora do gene, principalmente envolvendo os MREs (Somji et al., 2010).

\subsubsection{Tireoide}

Com respeito ao nível de expressão da MT nos carcinomas de tireoide, existem contradições, sendo que já foi demonstrado tanto um aumento quanto uma redução da MT nos tumores em relação ao tecido normal (Nartey et al., 1987; Ferrario et al., 2008; Schmid et al., 2008). O trabalho mais antigo mostrou que a MT encontra-se mais concentrada nos tumores em relação aos tecidos normais, ressaltando que a marcação estritamente nuclear foi vista com maior frequência em adenomas foliculares, enquanto marcação nuclear e citoplasmática foi observada nos adenocarcinomas foliculares e papilares (Nartey et al., 1987). Os estudos posteriores mostram resultados distintos destes, porém mais confiáveis, pois o uso do anticorpo E9 da Dako (Carpinteria) foi comum aos mesmos. Assim, foi identificado que na verdade há uma queda de marcação, principalmente para casos de carcinomas 
papilares da tireoide, com achados variáveis de marcação, relativamente maior para carcinomas foliculares, porém sempre com queda de expressão em relação aos tecidos normais (Ferrario et al., 2008; Schmid et al., 2008; Królicka et al., 2010). Schmid e colegas (2008) encontraram uma proporção de mais de $50 \%$ de positividade celular nos adenomas foliculares, nível semelhante ao do tecido normal. Os carcinomas foliculares também apresentaram uma proporção de células marcadas semelhante a esta, sem diferenças entre áreas sólidas e trabeculares. Por outro lado para os casos de carcinomas papilares, que são as malignidades mais comuns da tireoide, a maioria dos casos teve ausência completa de marcação, resultados também vistos para os casos de carcinomas medulares de tireoide (Schmid et al., 2008). Os resultados sugerem a MT como marcadora de diferenciação folicular, fato que merece melhor investigação. O estudo de Ferrario e colegas também evidencia a redução da MT nos tumores, entretanto demonstram que esta redução também ocorre nos carcinomas foliculares, numa fração de 22$60 \%$, e que para os carcinomas papilares, a redução foi de $28-75 \%$ (Ferrario et al., 2008).

Utilizando $P C R$ array em uma amostra de 25 pacientes, destacou-se a queda acentuada de expressão dos genes da MT1/2 e MT4 (Finn et al., 2007). Huang e colegas demonstraram que a queda de expressão do MT1G se dá por hipermetilação, o que ocorreu com maior frequência em pacientes do sexo masculino, que são reconhecidamente dotados de piores prognósticos (Huang et al., 2003). Um trabalho posterior avaliou 59 amostras destes tumores, mostrando baixa expressão de MT1E em 80,9\% dos casos de carcinoma papilar de tireoide e $50 \%$ dos carcinomas foliculares; MT1G por sua vez teve baixa expressão em $60 \%$ de carcinomas papilares e $9 \%$ de carcinomas foliculares; $M T 1 X$ apenas em carcinomas papilares da tireoide (76\%); e MT2A em carcinomas papilares (65\%) e foliculares (40\%). Estes dados indicam que a baixa expressão de MT ocorre frequentemente em tumores epiteliais diferenciados de tireoide. Os autores confirmaram que há hipermetilação de $M T 1 G$, mostrando que seu restabelecimento por transfecção em células $\mathrm{K} 1$ provoca crescimento e tumorigenicidade reduzidos. Os dados apontam para a MT como potencial supressora de tumores da tireoide (Ferrario et al., 2008). 


\subsubsection{Testículos}

A observação de uma alta expressão de MT nos padrões papilarglandular quando comparado com massas tumorais sólidas, associado à sua localização periférica no tumor, sugeriram um padrão histomorfológico bem definido de expressão da MT para células em proliferação (Chin et al., 1993; Kontozoglou et al., 1989). Em outro estudo, seminomas marcam MT negativamente ou em intensidade fraca, independentemente do estágio clínico, enquanto muitos não-seminomas marcam intensamente a MT, principalmente aqueles mais avançados (Chin et al., 1993). Porém outro estudo subsequente mostra alta expressão de MT em seminomas com padrões muito similares independentemente do estágio tumoral (Eid et al., 1998). Sugere-se que esta expressão aumentada em relação ao estudo anterior se deva ao fato de que o primeiro não fez recuperação antigênica em suas reações, além de não usarem o anticorpo E9 da Dako, que parece ser o mais amplamente utilizado e aceito nos estudos.

Em relação ao prognóstico, foi relatado que o aumento de MT1/2 nestes tumores prediz melhor resposta a quimioterapia, contrário do que seria dito por outros estudos mostrando que a MT seria capaz de captar os agentes quimioterápicos e anular seus efeitos (Eid et al., 1998). Entretanto, este resultado não foi reproduzido por outro grupo de pesquisadores, que observou em sua amostra que a expressão proteica de MT é semelhante entre tumores responsivos e não responsivos ao tratamento (Meijer; Timmer, 2000).

\subsubsection{Próstata}

$\mathrm{Na}$ próstata humana normal, tanto estudos imunohistoquímicos como de radioimunoensaio, demonstraram a expressão de MT1/2. A reatividade para MT se dá em citoplasma e núcleo de células epiteliais glandulares. No geral, esta é mais intensa na zona periférica, moderada na zona transicional e fraca na zona central. Entretanto este padrão não é sempre seguido (Suzuki 
et al., 1991; Garrett et al., 2000). É sabido que a transformação neoplásica prostática causa desbalanço da homeostasia do Zn (cerca de $60-70 \%$ da quantidade de $\mathrm{Zn}$ esperada para uma célula normal) (Costello; Franklin, 1998). Tal distúrbio tem sido então correlacionado com a redução de transcrição da MT. Com o restabelecimento de Zn para estas células, obtevese também aumento de expressão da MT1/2 com menor significância para as células normais e maior significância para as malignas (Wei et al., 2008). Além disso, os estudos mostraram que o restabelecimento de $\mathrm{Zn}$ pode induzir as células prostáticas malignas a apoptose por vias mitocondriais (Feng et al., 2000). Tal fato pode estar ligado ao restabelecimento de função de diversas enzimas, que indiretamente seriam controladas pela MT, visto o seu poder de armazenamento e distribuição do Zn (Wei et al., 2008). Observa-se ainda uma tendência de perda de marcação de acordo com a progressão tumoral, fato que pode ser visualizado pela correlação inversa entre a expressão de MT com o grau de Gleason nos adenocarcinomas de próstata (Zhang et al., 1996; Moussa et al., 1997). Todos os tumores classificados como grau II de Gleason mostraram intensa marcação para MT1/2, enquanto tumores de alto grau (IV e V) tiveram marcação negativa para MT. Os tumores de grau III foram heterogêneos com marcação mista para MT. Não houve correlação entre o padrão de marcação de MT e o antígeno prostático específico (PSA) nestes pacientes (Moussa et al., 1997).

Um estudo utilizando RT-PCR convencional mostra que a MT presente nas células prostáticas normais se deve à expressão de MT1A, MT1E, MT1F, MT1X, e MT2A enquanto não expressam MT1B, MT1G, e MT1H. A expressão de MT1X e MT2A foram maiores que do restante. Nas culturas de células malignas observou-se uma redução da expressão principalmente de MT1A, MT1E e MT1X, sempre mantendo expressão de MT1F e MT2A. Nas cinco amostras de tumores avançados, os autores demonstram como achado principal a ausência de $M T 1 X$, com regularidade de $M T 2 A$ e variações de expressão de MT1A e MT1E (Garrett et al., 2000). Um dos trabalhos demonstra que há hipermetilação da região promotora de MT1G em alguns tumores, relacionando-se ao estágio tumoral, mas não ao grau de Gleason. Os autores identificaram esta metilação em todas as linhagens celulares de 
carcinoma prostático, porém, após tratamento demetilante não se observou alterações na expressão do MT1G (Henrique et al., 2005).

Algumas células epiteliais e estromais podem exibir baixos níveis de MT3, sendo esta aumentada em hiperplasias prostáticas intra-epiteliais, podendo ser aumentada em alguns tipos de adenocarcinomas (Garrett et al., 1999). No estudo de Wei e colaboradores (2008), também foi observado aumento significativo de MT3 para células de hiperplasia prostática benigna, mas ausência em células normais e células de carcinoma, fato que merece maiores esclarecimentos (Wei et al., 2008). Em estudo in vitro, células malignas PC-3 foram transfectadas com MT1E e MT3, obtendo como resultado que o crescimento celular foi inibido naquelas que tiveram o aumento extrínseco de MT3. Além disto, os autores demonstraram que estas células tornaram-se menos susceptíveis a agentes quimioterapeuticos (Dutta et al., 2002). Entretanto, não há uma concordância deste achado com os de Juang e colaboradores (2013), que observaram que a transfecção de MT3 para as células PC-3 resulta em aumento de proliferação celular, invasão e tumorigenicidade, demonstrando que este aumento esteve associado à queda de expressão do gene Ndrg1 e maspina (Juang et al., 2013).

\subsubsection{Fígado}

Em um fígado normal, estudos imunohistoquímicos mostram forte marcação para a MT, sendo esta uniformemente distribuída entre núcleo e citoplasma (Tao et al., 2007). Todos os outros tecidos hepáticos incluindo ductos biliares e vasos sanguíneos apresentam marcação negativa. De forma contrária, os tumores hepáticos tendem a perder a MT, fato que leva a sugerir a MT como marcador de diferenciação celular para hepatócitos (Deng et al., 1998; Endo et al., 2004; Tao et al., 2007; Datta et al., 2007). A marcação de MT1/2 foi fraca no citoplasma, preservando mais em núcleo dos carcinomas pobremente diferenciados, sendo a frequência nuclear mais comum nestes do que nos bem diferenciados e moderadamente diferenciados (Tao et al., 2007). 
O tamanho tumoral também é influenciado, sendo que tumores maiores que dois centímetros têm menor positividade de marcação com relação aos menores que dois centímetros (Tao et al., 2007).

Os estudos com microarrays para expressão gênica mostram queda de expressão para MT1A, MT1B, MT1E, MT1F, MT1G, MT1H, MT3 e MT4 (lizuka et al., 2005; lizuka et al., 2002; Kanda et al., 2009). Alguns autores demonstraram que há hipermetilação da região promotora de $M T 1 G$ na maioria dos tumores e em algumas das amostras de tecidos não-malignos (Kanda et al., 2009). Outros pesquisadores mostraram que a repressão das MTs é mediada por ativação da via PI3K/AKT, induzindo desfosforilação do fator de transcrição C/EBP-alfa (Datta et al., 2007).

\subsubsection{Rins}

O estudo mais tradicional, que deu início ao conhecimento das MTs foi realizado tendo como material tecidos renais ora equinos (Margoshes; Vallee, 1957). A expressão de $M T 1 / 2$ é relativamente intensa nos rins quando comparado a outros órgãos, sendo um componente celular renal em estado fisiológico, estando presente nos túbulos proximais dos néfrons. Esta presença de MT se dá tanto para rins fetais quanto para adultos, não sendo associada a nenhuma alteração patológica (Mididoddi et al., 1996). Em se tratando de neoplasias renais, ocorre expressão de MTs em núcleo e citoplasma, sendo esta maior nos tumores de alto grau, fato que ainda não foi bem investigado.

Utilizando primers para RT-PCR foi demonstrado que transcrições dos genes MT2A, MT1E, MT1F e MT1X são comuns no rim normal. Foram encontradas poucas transcrições de $M T 1 A$, e ainda nenhuma expressão de MT1B, MT1G, MT1H, MT3 e MT4 (Mididoddi et al., 1996; Nguyen et al., 2000). Quanto às atividades gênicas nas neoplasias, observa-se um aumento de duas vezes na expressão de MT2A, diminuição de $M T 1 A$ e de $M T 1 G$, enquanto níveis semelhantes ao das células normais foram observados para 
as transcrições de MT1E, MT1F e MT1X (Nguyen et al., 2000). A presença de MT3 também foi detectada em rins normais, neoplasias renais e cultura de células de túbulo proximal humano (Hoey et al., 1997). Este estudo demonstra níveis baixos de MT3 quando comparado à sua expressão em tecidos neurais. Desta forma, para sua expressão em tecidos cerebrais são necessários apenas $500 \mathrm{ng}$ de RNA e 25 ciclos de reação, enquanto para uma expressão semelhante em tecidos renais, são necessários $1000 \mathrm{ng}$ de RNA e 29-34 ciclos. Outro estudo não demonstrou a presença de MT3 em

rins por executar apenas 30 ciclos de RT-PCR convencional, o que foi suficiente para alta detecção de MT2A e MT1X, e também seria suficiente para encontrar expressão de $M T 3$ em células cerebrais, mas não nas renais (Mididoddi et al., 1996). No que diz respeito a neoplasias, a MT3 não distingue as mesmas de células normais (Hoey et al., 1997).

\subsubsection{Bexiga}

A mucosa normal da bexiga usualmente não apresenta níveis proteicos detectáveis de $M T 1 / 2$, podendo haver uma fraca marcação de fundo em camada de músculo liso e nas células uroteliais (Somji et al., 2001; Yamasaki et al., 2006). Em um ensaio imunohistoquimico, encontrou-se taxa de positividade para expressão imunohistoquímica de MT de 4,3\% para tumores grau I, 35,7\% para grau II e 64,5\% para grau III. Além disso, também houve correlação com o estágio clínico, onde tumores aquém do estágio T2 tiveram $25,8 \%$ e tumores T2 ou mais avançados, 58,6\%. Quanto ao aspecto histológico, os tumores papilares tiveram $22 \%$ e os não-papilares $62,5 \%$. Assim, houve maior expressão de MT em casos com critérios clínicos e histopatológicos condizentes com pior prognóstico (Saga et al., 2002). Yamasaki e colegas (2006), utilizaram o "quickscore", que avalia tanto a intensidade como a proporção de células positivas, e detectaram correlação significativa entre alto escore de expressão da MT e sobrevida global, doença-específica, e ainda progressão livre de doença (Yamasaki et al., 
2006). Dois outros trabalhos, entretanto, mostraram resultados invertidos, sendo a alta expressão de MT relacionada a um menor grau histológico e menor estágio clínico (Kotoh et al., 1994; Saika et al., 1994). Tais resultados podem ser devido a diferenças em anticorpos, métodos e/ou interpretação dos resultados imunohistoquímicos. Além disso, a maioria dos estudos utilizam o anticorpo E9 para avaliação da MT, enquanto estes dois estudos utilizaram outro.

Com relação à expressão gênica, parece que a expressão de MT1E é variável tanto no tecido normal quanto no canceroso, e que estão presentes ARNm para MT2A e MT1X em ambos os tecidos. No entanto, MT1X esteve altamente expresso nos carcinomas e totalmente indetectável em células normais. Este estudo sugere que o aumento de expressão de MT1/2 em carcinomas de bexiga se deve ao aumento de expressão do gene MT1X (Somji et al., 2001). A isoforma proteica MT3 também foi testada como marcador de prognóstico para neoplasias de bexiga. $O$ estudo demonstrou que nem por imunohistoquimica nem por PCR esta isoforma foi detectada nos tecidos normais e células normais em cultura. Marcações fracas foram obtidas em displasias, e, nos tumores, observou-se aumento da intensidade de marcação correlacionando-se positivamente com o aumento do grau de malignidade tumoral. Entretanto, a expressão gênica de $M T 3$ não seguiu o mesmo parâmetro (Sens et al., 2001).

\subsubsection{Pulmões}

De 62 casos de carcinomas de pulmão de células não pequenas, $89,9 \%$ demonstraram aumento de expressão de MT1/2. Os resultados de qPCR mostraram que uma expressão significativamente aumentada nos tumores em relação ao tecido não-maligno foi obtida para $M T 1 B, M T 1 F$, MT1G, MT1H, e MT1X, enquanto que apenas o MT1E esteve significativamente reduzido. Não houve diferenças entre MT2A e MT1A dentre os grupos. Uma correlação significativa foi obtida entre a imunohistoquímica 
para MT1/2 e a expressão de MT1X. O ARNm de MT4 foi detectado em apenas 2 casos. Casos classificados como de alta expressão de $M T 1 F$ e MT1A foram associados a maior tamanho do tumor primário (pT2-4), sendo que esta associação ainda foi obtida entre $M T 1 F$ e casos de maior grau de malignidade e MT1F e pior sobrevida, esta última também obtida para casos de maior expressão de MT2A. Assim, os autores concluem que os níveis de MT1F e MT2A podem ser considerados como marcadores de prognóstico para pacientes com carcinomas de pulmão de células não pequenas (Werynska et al., 2013b).

A MT3 foi observada em citoplasma e núcleo de pneumócitos normais e em Carcinoma de pulmão de células não pequenas NSCLC. Observou-se menor expressão nuclear nestes carcinomas do que no tecido pulmonar nãomaligno. Entretanto, houve relação oposta para a expressão citoplasmática, que foi maior nos tumores do que no tecido não-maligno. Tal expressão citoplasmática, entretanto, não reflete em diferenciação histológica tumoral nem em grau histológico, sendo apenas visto que uma expressão citoplasmática menor foi associada com tumores do tipo adenocarcinomas de tamanhos maiores. Utilizando o PCR, foi observado que o gene MT3 está mais ativo nos carcinomas epidermoides de pulmão em relação ao tecido não-maligno. A expressão gênica não esteve relacionada à idade, gênero, grau de malignidade, tamanho tumoral. Porém, a baixa expressão do MT3 esteve associada com pior sobrevida (Werynska et al., 2013a). 


\section{PROPOSIÇÃO}

O presente trabalho tem como objetivo avaliar o padrão de transcrição dos genes MT1A, MT1B, MT1E, MT1F, MT1G, MT1H, MT1X, MT2A, MT3 e MT4 em amostras de CEB armazenadas no banco de tumores do Instituto Nacional de Câncer (INCA) no período de 2007 a 2009. Serão considerados como fatores do estudo os aspectos clínicopatológicos (idade, sexo, uso do tabaco, uso do álcool, topografia das lesões, tamanho segundo classificação do TNM, grau histológico, intensidade de infiltrado inflamatório, presença de invasão perineural, recidivas, metástases), a sobrevida dos pacientes, e a quantificação de ARNm das isoformas das MT.

\section{OBJETIVOS ESPECÍFICOS}

a. Tabular e realizar estatística descritiva dos dados clinicopatológicos da amostra;

b. Identificar e quantificar a expressão gênica das diferentes isoformas das MTs nos fragmentos cirúrgicos de CEB e de mucosa oral correspondente (MOC) a cada paciente coletados dentre o período 2008 e 2009 e armazenados no Banco Nacional de Tumores (BNT) do INCA;

c. Tabular as características da expressão gênica das MTs nas amostras de CEB e MOC;

d. Comparar a expressão gênica normalizada de CEB com características clínicopatológicas e fatores clássicos relacionados ao prognóstico do CEB, tais como: idade dos pacientes (> ou < que 45 anos), sexo, hábitos como tabagismo e etilismo, topografia do CEB, tamanho tumoral categorizado segundo TNM, envolvimento metastático linfonodal e à distânicia, grau histológico segundo a Organização Mundial de Saúde e estádio tumoral segundo sistema TNM. 


\section{MATERIAL E MÉTODOS}

\subsection{AMOSTRA}

O presente protocolo de pesquisa foi aprovado pelo Comitê de Ética em Pesquisa (CEP) do Instituto Nacional de Câncer (INCA) sob o registro 48/11 e parecer consubstanciado do CEP da Faculdade de Odontologia da Universidade de São Paulo sob o número 47833 gerado na Plataforma Brasil (Anexos A e B).

Utilizou-se uma amostra de conveniência de fragmentos de carcinoma epidermoide bucal (CEB) e fragmentos de mucosa oral correspondente (MOC) a cada caso, armazenados em freezer a $-80^{\circ}$ no Banco Nacional de Tumores do INCA (BNT-INCA) no período de 2007 a 2009. O critério de inclusão foi amostras de CEB que envolvessem língua e/ou assoalho bucal.

As informações clínico-demográficas e de acompanhamento dos pacientes foram obtidas a partir de consulta aos prontuários do arquivo médico do INCA. Os dados levantados incluíram: sexo, tabagismo, etilismo, queixa dos pacientes, localização dos tumores, tamanho, tratamento realizado, informações sobre metástase, recidivas e sobrevida.

\subsection{MÉTODOS}

\subsubsection{Avaliação dos fragmentos teciduais e macrodissecção}

Todos os fragmentos obtidos foram avaliados macroscopicamente e microscopicamente. Para tal, cortes histológicos, denominados de "lâminas espelho", foram obtidos para cada fragmento a partir de secções histológicas 
dos mesmos em criostato. Tais secções foram coradas com azul de toluidina (1\%) por 1 minuto, seguida de enxágue em água (Figura 4.1).

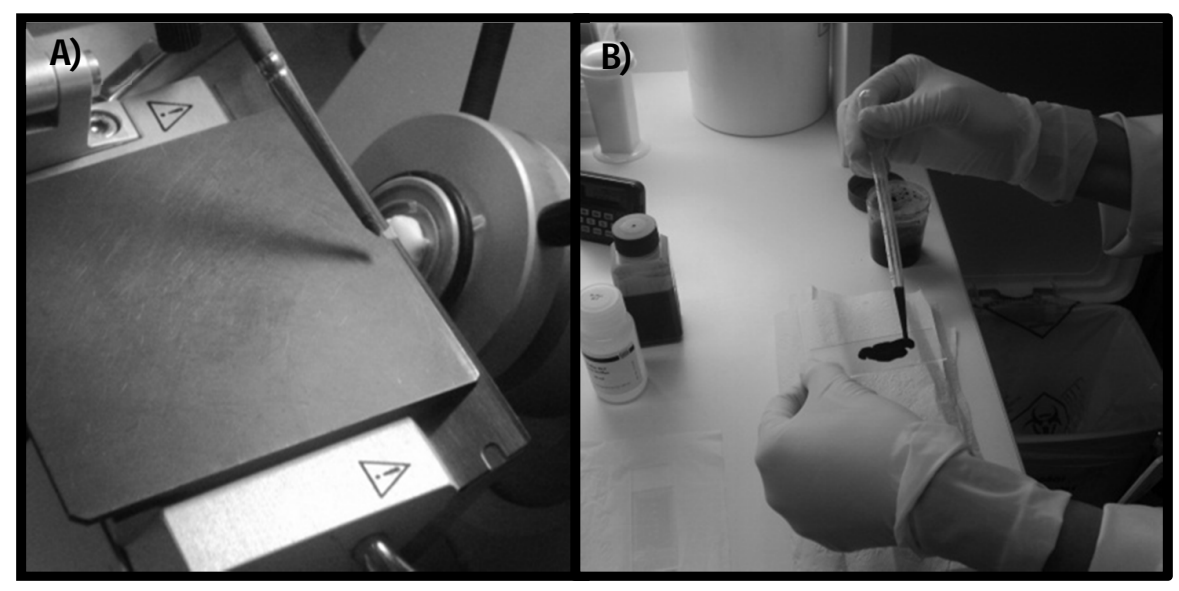

Figura 4.1 -A) Corte histológico em criostato dos fragmentos armazenados no BNT. B) Coloração com azul de toluidina a $1 \%$ para visualização da lâmina espelho do caso

Um dos objetivos de uso das lâminas espelho foi confirmar a presença do CEB e confirmar a presença de EOC íntegro nos devidos fragmentos. Após confirmação histológica, as lâminas foram fundamentais para estabelecimento de parâmetros para a macrodissecção. O objetivo da macrodissecção foi a obtenção de fragmentos contendo no mínimo $70 \%$ de tecido alvo, que seriam os grupamentos de células neoplásicas para o estudo do CEB (ilhotas, lençóis de invasão celular, etc.), e um fragmento de epitélio oral íntegro, eliminando ao máximo o tecido conjuntivo da lâmina própria e tecidos contaminantes para as análises, como músculo, tecido adiposo e glândulas salivares menores. Na figura 6 observa-se uma simulação de áreas eliminadas com o bisturi após interpretação do fragmento com o auxílio da lâmina espelho (Figura 4.2). 


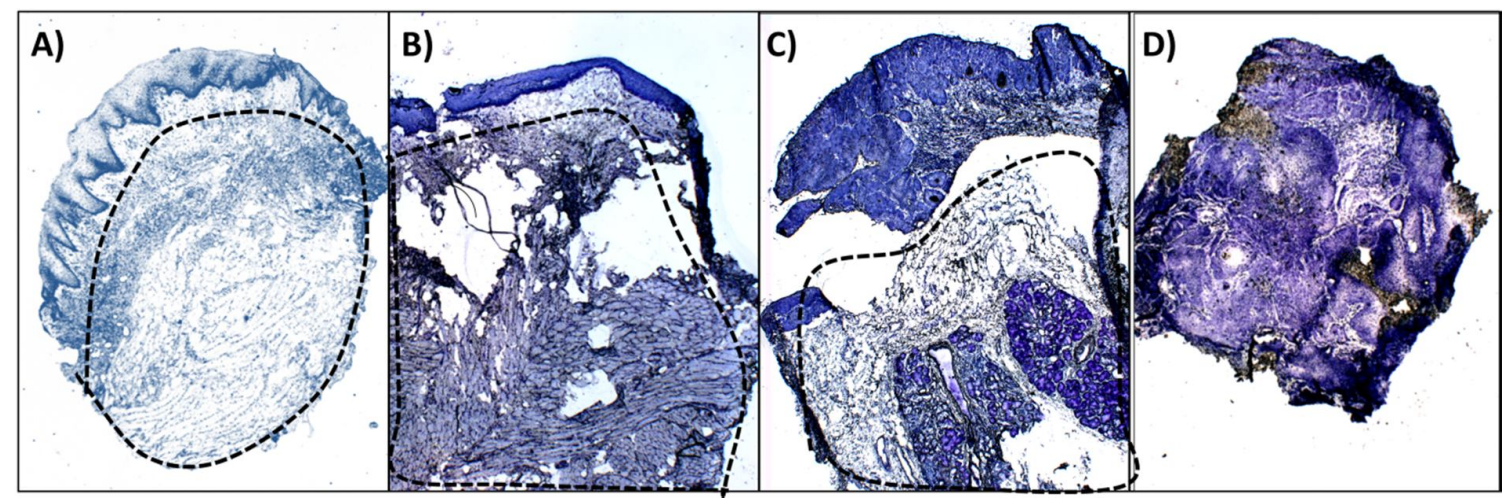

Figura 4.2 - Painel de lâminas espelho elaboradas a partir dos fragmentos de CEB e EOC coletados. Nas áreas tracejadas observa-se uma simulação de áreas a serem eliminadas com o bisturi na macrodissecção. A) fragmento de EOC com extensa área de tecido conjuntivo eliminada. B) fragmento de EOC com área de tecido conjuntivo e músculo eliminadas na macrodissecção. C) fragmento de CEB com área de tecido conjuntivo e glândula salivar menor eliminadas na macrodissecção. D) Fragmento de CEB com grande quantidade de tumor, sem necessidade de macrodissecção (>70\% de tumor)

A partir das lâminas espelho, também foi possível avaliar o grau histológico tumoral e o infiltrado inflamatório, caso presente. Tais características foram confirmadas posteriormente por avaliação das lâminas em H.E dos fragmentos que ficam arquivadas como registro de entrada dos fragmentos no BNT. O grau histológico tumoral foi estabelecido segundo a classificação tradicional da Organização Mundial de Saúde, no qual tumores bem diferenciados correspondem àqueles em que 0 tumor mantém características muito semelhantes ao epitélio oral normal, tumores moderadamente diferenciados são aqueles que contêm pleomorfismo nuclear e atividade mitótica distintos, porém, usualmente, uma menor queratinização. Tumores pobremente diferenciados são constituídos por células predominantemente imaturas, com numerosas mitoses, por vezes atípicas, e queratinização mínima (Cardesa et al., 2005). O infiltrado inflamatório foi avaliado categorizando os casos em casos de infiltrado inflamatório ausente ou leve e casos de infiltrado inflamatório moderado ou intenso. 


\subsubsection{Extração do RNA e transcrição reversa}

Após macrodissecção, seguiu-se para o protocolo estabelecido para extração de RNA utilizando o RNeasy microkit da Qiagen, da seguinte maneira: os tecidos macrodissecados foram seccionados em fragmentos menores com o bisturi e colocados em tubos eppendorf de $2 \mathrm{ml}$ contendo 350 ul de uma solução composta por tampão RLT (KIT RNease, Qiagen) e Bmercaptoetanol. Tal solução foi elaborada adicionando-se $10 \mathrm{ul}$ de Bmercaptoetanol para cada $1 \mathrm{ml}$ de buffer RLT. Em seguida, foi realizada a trituração do tecido com mixer Omni $\mu \mathrm{H}$, Micro Homogenizer (OMNI International) no interior do tubo ependorf, o qual permaneceu no gelo durante todo o procedimento. Após a homogeneização de cada fragmento tecidual, a sonda do triturador seguiu para um protocolo de limpeza, que constou de ativação da máquina em tubos falcon de $15 \mathrm{ml}$ com soluções para limpeza, na sequência: água miliQ; álcool absoluto (3 vezes); finalizando em água DEPC (Figura 4.3). Os tubos foram desprezados após única utilização.

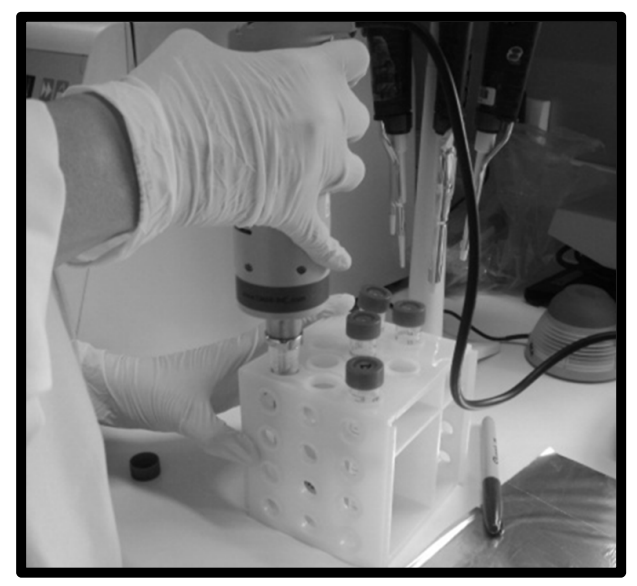

Figura 4.3 - Demonstração de protocolo de higienização do triturador de tecidos $(O m n i \mu \mathrm{H}$, Micro Homogenizer) após uso em cada um dos fragmentos utilizados no estudo 
Após trituração, as amostras foram levadas para centrífuga por 3 minutos a $13.000 \mathrm{rpm}$ no equipamento Heraeus sorvall high-speed benchtop centrifuge. Ao sobrenadante obtido acrescentou-se 350 ul de álcool $70 \%$, fazendo movimentos de up and down. O material foi transferido para a coluna de purificação de RNA fornecida pelo kit e posteriormente, centrifugado a $13.000 \mathrm{rpm}$ por $1 \mathrm{~min}$, seguindo o protocolo do fabricante. Descartou-se o material que atravessou a coluna, e adicionou-se 350 ul de buffer RW1 (Kit RNeasy), passando por nova centrifugação de $1 \mathrm{~min}$ a 13.000 RPM. Em seguida, as amostras na coluna foram incubadas com enzima de quebra de ADN (DNAse) por 15 min em temperatura. Posteriormente adicionou-se mais 350 ul de buffer RW1 e as colunas foram centrifugadas por 1 min a 13.000 RPM. Em seguida, descartou-se o líquido do tubo e foram adicionados $500 \mathrm{ul}$ de RPE (com etanol), passando por mais uma centrifugação de 1 min a 13.000 RPM. Logo, prossegue-se para uma centrifugação com álcool 80\%, de 2 min a 13.000 RPM. Após este passo, seguiu-se com uma centrifugação com tampa aberta, sem adicionar nenhum líquido, por 5 min a 13.000 RPM para secagem da membrana no qual o RNA estava precipitado. Finalmente, adicionou-se 14 ul de água RNase-free direto no centro da coluna, centrifugando por 1 min a 13.000 RPM para eluição do RNA.

Após extração do RNA, todos os casos foram avaliados e mensurados por espectrofotometria no equipamento NanoDrop ${ }^{\mathrm{TM}} 2000$ (Thermo Scientific), cuja razão OD 260 e 280 variou entre 1,3 e 1,9. A qualidade do RNA foi avaliada por meio de géis de agarose $2 \%$, utilizando $1 \mathrm{mg}$ de RNA de amostra, variável quantidade de água MiliQ para completar volume de $10 \mathrm{ul}$, e mais 10 ul de RNA loading em cada poço do gel. O resultado foi considerado ótimo quando bandas $28 \mathrm{~S}$ e $18 \mathrm{~S}$ de RNAr estavam nítidas e intensas, numa razão 2:1. As amostras 3, 4 e 7 da figura 4.4, seguindo da esquerda para a direita, foram consideradas inadequadas. Para os casos onde as amostras eram escassas, considerando o resultado obtido pela avaliação no NanoDrop ${ }^{\mathrm{TM}}$, prosseguiu-se diretamente para a etapa de qPCR utilizando o primer para avaliação da expressão da gliceraldeído-3-fosfato desidrogenase (GAPDH), a fim de poupar amostra para as reações subsequentes de qPCR. As amostras que apresentaram ausência de expressão para o gene constitutivo GAPDH foram excluídas do estudo. 


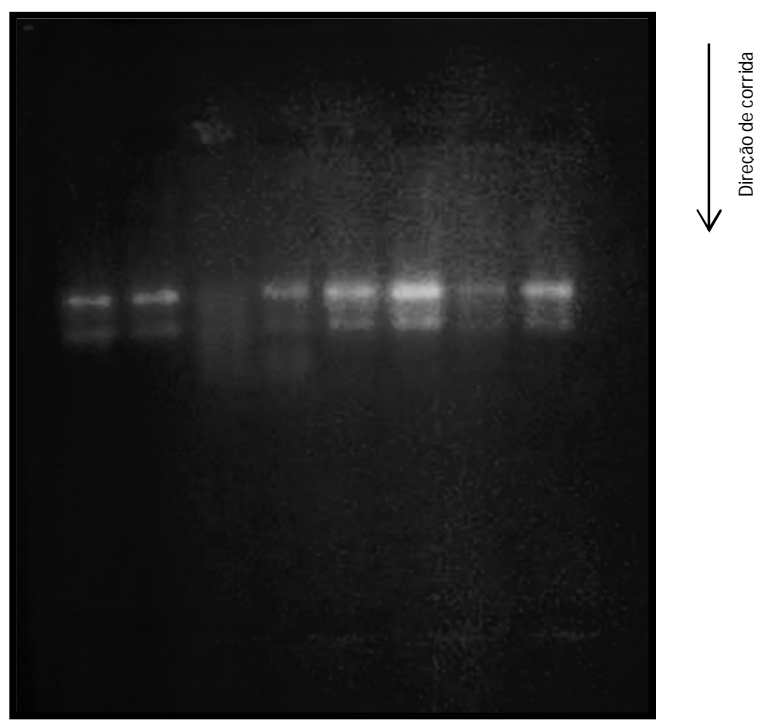

Figura 4.4 - Avaliação de integridade do RNA das amostras por corrida em gel de agarose $2 \%$ para visualização das subunidades $18 \mathrm{~S}$ e $28 \mathrm{~S}$ do RNA ribossômico. As amostras 3, 4 e 7 foram consideradas inadequadas e excluídas do estudo

A transcrição reversa para síntese do ADN complementar (ADNc) foi realizada com o kit High Capacity cDNA Reverse Transcription Kit (Applied Biosystems) seguindo as instruções do fabricante. Para tal, padronizou-se um input de 80 ng de ADNc para cada amostra, completando o volume da reação para 10 ul com 1,0 ul de DNase 1 (Invitrogen ${ }^{\mathrm{TM}}$ ), 1 ul do tampão buffer DNase 10x (Invitrogen ${ }^{\mathrm{TM}}$ ) e quantidade variável de água RNase-free (Sigma). Após 15 minutos em temperatura ambiente da mistura destes componentes, adicionou-se 1 ul de EDTA em pH8, e a solução foi levada em termociclador à 65 C por 10 minutos para inativação da DNAse. Paralelamente, foi elaborado um mix de volume de $10 \mathrm{ul}$, contendo os outros componentes do kit High Capacity cDNA Reverse Transcription Kit (Applied Biosystems), a saber: $\mathrm{H}_{2} \mathrm{O}$ DEPC (3,2 ul); 10x RT Buffer (2,0 ul); dNTP mix (0,8 ul); random primers (2,0 ul); RNase Out (1,0 ul); enzima Multiscribe (1,0 ul). Finalmente, misturou-se o mix descrito inicialmente com este, e então se prosseguiu para execução das reações em termociclador, adotando os parâmetros descritos pelo fabricante:1) 25으 C por 10 minutos; 2) 37ㅇ C por 2 horas; 3) 85 C por 5 minutos; 4) Estocagem e armazenamento do ADNc em freezer $-30^{\circ} \mathrm{C}$. 


\subsubsection{Reação em cadeia da polimerase (PCR)}

Para detecção da expressão gênica das diferentes isoformas de MT, utilizou-se um ensaio de PCR quantitativo em tempo real (qPCR) com a tecnologia TaqMan ${ }^{\circledR}$. Os iniciadores ou primers foram desenhados e padronizados pela Applied Biossistems, que os disponibiliza em seu catálago sob a forma de ensaios inventariados, no formato all-in-one, ou assays in single tubes, onde ambos os primers (forward e reverse) e a sonda TaqMan ${ }^{\circledR}$ são armazenados em tubo único, em concentrações otimizadas para obtenção de melhor eficiência. A emissão de fluorescência deste ensaio é dada pelo fluoróforo FAM ${ }^{\mathrm{TM}}$ (reporter) após quebra da sonda pela ação da enzima ADN polimerase a cada ciclo do qPCR. Liberando o fluoróforo $F A M^{T M}$, elimina-se 0 efeito supressor (quencher) de fluorescência do corante TAMRA $^{\text {TM }}$ que se encontra aderido à sonda por ligação covalente. A tabela 4.1 descreve as características individuais dos ensaios adquiridos para identificação de cada isoforma da MT por meio do qPCR.

Para a execução das reações, utilizou-se ainda o $\operatorname{TaqMan}^{\circledR}$ Universal Master Mix II, with UNG (Life Technologies). Trata-se de um tubo maior contendo todos os demais componentes necessários para as reaçõs do qPCR, também disponibilizados em concentração otimizada pela empresa, a saber: enzima ADN-polimerase AmpliTaq Gold®; Uracil-ADN glicosilase; dTNPs com dUTP; fluorescência de referência passiva ROX ${ }^{\mathrm{TM}}$; componentes de tampão otimizados; e AmpErase ${ }^{\circledR}$ UNG, que protege contra novas amplificações de produtos de PCR contendo dU para minimizar contaminação tipo carry-over. 
Tabela 4.1 - Relação das isoformas da Metalotioneína e características dos ensaios desenhados pela Applied Biosystems para sua identificação por meio de qPCR

\begin{tabular}{lcccc}
\hline \hline Gene & $\begin{array}{c}\text { ID Life } \\
\text { Technol. }\end{array}$ & \multicolumn{1}{c}{ Sequência da sonda } & $\begin{array}{c}\text { Exon } \\
\text { alvo }\end{array}$ & $\begin{array}{c}\text { Ref. Seq. } \\
\text { NCBI }\end{array}$ \\
\hline MT1A & Hs00831826_s1 & AGTGCAGCTGCTGTGCCTGATGTCC & 3 & NM_005946.2 \\
MT1B & Hs01875377_s1 & CTGACCGGTTGCTACATTCTTTT & 4 & NM_005947.2 \\
MT1E & Hs01938284_g1 & AGGGCAGGGAGGTGCCCGGTCAAGT & & AF495759.1 \\
MT1F & Hs00744661_sH & TTATACCACCTTGACCCATTTGCTA & 4 & NM_005949.3 \\
MT1G & Hs02578922_gH & GAAGTGCAGCTGCTGCGCCTGATGT & 3 & NM_005950.1 \\
MT1H & Hs00823168_g1 & TACAACTCCGACTCATTTGCTACAT & 4 & NM_005951.2,X6 \\
& & & & 4177.1 \\
MT1X & Hs00745167_sH & GTGCCTGATGCCAGGACAGCTGTGC & 3 & NM_005952.3 \\
MT2A & Hs02379661_g1 & TTATGTACAACCCTGACCGTGACCG & 4 & NM_005953.3 \\
MT3 & Hs01921768_s1 & CCCCTTCCCCTGCTGACCTTGGAGG & 6 & NM_005954.2 \\
MT4 & Hs00262914_m1 & GTCTGCATGTCTGGAGGATCTGCA & 1 & NM_032935.2 \\
GAPDH & Hs03929097_g1 & CAAGAGGAAGAGAGAGACCCTCACT & 12 & NM_001256799. \\
& & & & 1 \\
\hline
\end{tabular}

O aparelho 7500 Real Time PCR Systems (Applied Biosystems) foi utilizado para a execução das reações, as quais foram realizadas em triplicata em placas ópticas de 96 poços (Axygen ${ }^{\circledR}$ ), seguindo o protocolo: 3,5 ul de água $R$ Nase-free; 0,5 ul de primers (assays in single tubes); 5,0 ul da solução universal (TaqMan ${ }^{\circledR}$ Universal Master Mix II, with UNG); e 1 ul de amostra (ADNc). Em seguida as placas foram centrifugadas em centrífuga refrigerada (Eppendorf $5810 \mathrm{R}$ ) a $4000 \mathrm{rpm}$ por 2 min em temperatura $4^{\circ} \mathrm{C}$, e colocadas no equipamento de $\mathrm{qPCR}$, seguindo as temperaturas de ciclagem recomendadas pelo fabricante (Figura 4.5).

\begin{tabular}{|l|c|c|c|}
\hline \multirow{2}{*}{ System } & \multicolumn{3}{|c|}{ Thermal cycling conditions } \\
\cline { 2 - 4 } & Stage & $\begin{array}{c}\text { Temp } \\
\mathbf{l}^{\circ} \mathbf{C} \text { ) }\end{array}$ & $\begin{array}{c}\text { Time } \\
\text { (mm:ss) }\end{array}$ \\
\hline $\begin{array}{l}\text { Applied Biosystems 7300/7500 } \\
\text { Real-Time PCR System }\end{array}$ & Hold $\S$ & 50 & $2: 00$ \\
\hline & Hold & 95 & $10: 00$ \\
\hline & $\begin{array}{c}\text { Cycle } \\
\text { (40 Cycles) }\end{array}$ & 95 & $0: 15$ \\
\hline
\end{tabular}

Figura 4.5 - Configuração recomendada para qPCR segundo o manual da Applied Biosystems 


\subsubsection{Análise do qPCR}

Para a determinação da eficiência de amplificação dos alvos em tempo real foram obtidas curvas padrão utilizando diluições seriadas em log de 5 de DNAc proveniente de células SCC-9 (linhagem comercial de carcinoma epidermoide de língua fornecida pela American Type Culture Collection) para cada isoforma da MT e para o gene constitutivo GAPDH, da seguinte forma: $1 / 1,1 / 5,1 / 25,1 / 125,1 / 625$. Três pontos, no mínimo, foram usados para a construção das curvas padrão, gerando um gráfico de regressão linear. Para estimar a eficiência $(E)$ do ensaio de PCR em tempo real foi realizado o seguinte cálculo: $E=\left(10^{-1 / \text { slope }}-1\right) \times 100$. Considerou-se eficiência aceitável quando situada entre o intervalo $80 \%$ a $120 \%$. Para cada curva padrão o software procura o melhor ajuste entre os pontos e calcula a regressão linear fornecendo o $R^{2}$ (ideal $R^{2} \geq 0.99$ ).

Para a quantificação relativa dos genes da MT estudados no presente estudo, todas as amostras experimentais foram amplificadas em triplicata e a quantidade normalizada do gene-alvo foi determinada a partir da equação da reta obtida por meio da curva-padrão de cada gene. No exemplo da figura 4.6 observa-se uma curva padrão obtida para o gene MT2A e a equação da reta obtida. A expressão normalizada relativa para a amostra é representada pela incógnita $X$ na equação, que é então obtida após conclusão da equação com a substituição da variável Y pelo valor de Ct obtido no qPCR para a amostra.

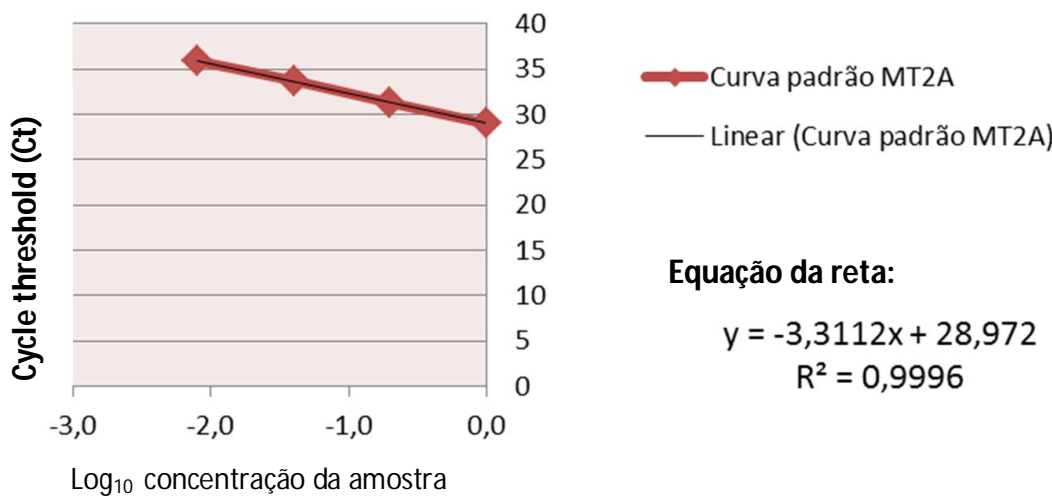

Figura 4.6 - Exemplo de curva padrão obtida a para o gene MT2A partir da diluição de amostras de SCC9 em $5 \operatorname{logs}$ 


\subsubsection{Análise dos dados}

Os dados de expressão obtidos foram analisados com auxílio do software GraphPad Prism 5 (GraphPad Software Inc., San Diego, CA). As análises comparativas foram precedidas da realização do teste de normalidade de Kolmogorov-Smirnov para definir se os dados eram paramétricos ou não paramétricos. Esta análise foi considerada para determinar a forma de representação nas tabelas a partir da estatística descritiva dos dados. Para dados não paramétricos a representação dos valores será feita por mediana e valores mínimos e máximos. Para dados paramétricos a representação dos valores será feira por média e desvio padrão.

Os valores numéricos de expressão de cada gene obtidos a partir da equação da reta correspondente foram utilizados para as análises. Todos os dados clínico-patológicos foram utilizados para comparações dos valores de expressão entre grupos, como as comparações a partir do tamanho tumoral, grau histológico, comportamento metastático e estágio do TNM. Os tumores ainda foram classificados como "CEB de alta expressão" e "CEB de baixa expressão". A mediana de expressão obtida a partir da análise das amostras de mucosa oral correspondente (MOC) aos casos de CEB representou o ponto de definição do que se tratou como "CEB de alta expressão" e "CEB de baixa expressão". Casos de CEB que tiveram expressão superior à mediana obtida para MOC representaram casos de alta expressão e casos de CEB que tiveram expressão inferior à obtida para MOC representaram casos de baixa expressão. Esta divisão foi utilizada para as comparações com os dados clínico-patológicos por meio de análise de tabelas de contingência.

O teste de Mann-Whitney foi empregado para as análises comparativas de grupos, como exemplo, para comparação entre grupos de tumores metastáticos e tumores não metastáticos. Para as comparações entre três grupos independentes ou mais (Tamanho segundo o sistema TNM, grau histológico de malignidade), o teste utilizado foi o de Kruskal-Wallis seguido de pós-teste de Dunns. Especificamente para as comparações entre CEB e MOC, utilizou-se o teste de Wilcoxon, que é para dados não 
paramétricos e para amostras pareadas. Variáveis categóricas, como as comparações entre tumores de alta expressão e tumores de baixa expressão, foram avaliadas pelo teste Exato de Fisher quando havia dois grupos comparativos ou pelo teste do Qui-quadrado (x2) quando havia mais de dois grupos comparativos.

As curvas de sobrevida global foram estabelecidas por meio do método de Kaplan-Meier e comparadas pelo teste de Cox-Mantel. Os dados clinicodemográficos que classicamente fornecem informações de prognóstico, como tamanho tumoral, grau histológico, comportamento metastático e estágio do TNM foram testados quando à capacidade preditiva de sobrevida para a presente amostra. 


\section{RESULTADOS}

\subsection{DADOS CLÍNICO-PATOLÓGICOS}

A tabela 5.1 identifica as principais características clínico-patológicas dos casos de CEB incluídos no estudo. Trinta e cinco casos foram incluídos na amostra de estudo. Os pacientes tinham em média 59,5 anos $( \pm 13,3)$, sendo a maioria do sexo masculino $(77,1 \%$; masculino/feminino=3,37). Com relação a hábitos nocivos, 25 pacientes forneceram informações sobre uso do tabaco. Destes, $57,1 \%(n=20)$ declararam-se tabagistas, e o tempo médio de uso foi de 37,4 anos $( \pm 7,6)$, com quantidade média de 26,5 $( \pm 11,0)$ cigarros/dia. De 24 pacientes, 17 declararam-se etilistas, com tempo médio de $33,3( \pm 13,3)$ anos. O tempo médio de sintomas relacionados ao CEB pode ser calculado para 26 pacientes, dando uma média de 8,5 meses, com a queixa principal de "ferida na boca" como a mais comum ( $n=15 ; 42,8 \%)$. A sintomatologia dolorosa foi observada em $14,3 \%$ dos casos, e para os casos remanescentes, observou-se disfonia, $(n=2 ; 5,7 \%)$, prurido $(n=1 ; 2,8 \%)$, e ausência de sintomas ( 3 casos). Seguindo os critérios de inclusão do estudo com relação à localização, obteve-se um maior número de casos com localização exclusivamente em borda de língua ( $n=19 ; 54,3 \%)$. Os outros casos envolviam língua e assoalho, sem distinção de epicentro tumoral $(n=8$; $22,8 \%$, ou somente assoalho bucal $(n=8 ; 22,8 \%)$. 
Tabela 5.1 - Dados clínicopatológicos referentes aos 35 casos de carcinomas epidermoides bucais incluídos no presente estudo

\begin{tabular}{|c|c|c|c|}
\hline PARÂMETROS & CATEGORIA & N. & (\%) \\
\hline $\begin{array}{c}\text { Idade } \\
\text { (média 59,5; } \mathrm{DP} \pm 13,3 \text { ) }\end{array}$ & $\begin{array}{l}35-60 \text { anos } \\
>60 \text { anos }\end{array}$ & $\begin{array}{l}20 \\
15\end{array}$ & $\begin{array}{l}57,1 \\
42,9\end{array}$ \\
\hline Sexo & $\begin{array}{l}\text { Masculino } \\
\text { Feminino }\end{array}$ & $\begin{array}{c}27 \\
8 \\
\end{array}$ & $\begin{array}{l}77,1 \\
22,8 \\
\end{array}$ \\
\hline Tabagismo & $\begin{array}{l}\text { Sim } \\
\text { Não } \\
\text { SI }\end{array}$ & $\begin{array}{c}20 \\
5 \\
10\end{array}$ & $\begin{array}{l}57,1 \\
14,3 \\
28,6\end{array}$ \\
\hline Etilismo & $\begin{array}{c}\text { Sim } \\
\text { Não } \\
\text { SI }\end{array}$ & $\begin{array}{c}17 \\
7 \\
11\end{array}$ & $\begin{array}{l}48,6 \\
20,0 \\
31,4\end{array}$ \\
\hline Queixa principal & $\begin{array}{c}\text { Dor } \\
\text { Ferida na boca } \\
\text { Outras } \\
\text { Ausente } \\
\text { SI }\end{array}$ & $\begin{array}{c}5 \\
15 \\
3 \\
3 \\
9\end{array}$ & $\begin{array}{l}14,3 \\
42,8 \\
17,1 \\
17,1 \\
25,7\end{array}$ \\
\hline Localização & $\begin{array}{c}\text { Língua } \\
\text { Assoalho } \\
\text { Língua e assoalho }\end{array}$ & $\begin{array}{c}19 \\
8 \\
8\end{array}$ & $\begin{array}{l}54,4 \\
22,8 \\
22,8\end{array}$ \\
\hline Dimensão clínica & $\begin{array}{l}\text { T1 } \\
\text { T2 } \\
\text { T3 } \\
\text { T4 } \\
\end{array}$ & $\begin{array}{c}5 \\
18 \\
11 \\
1 \\
\end{array}$ & $\begin{array}{c}14,3 \\
51,4 \\
31,4 \\
2,8 \\
\end{array}$ \\
\hline Grau histológico & $\begin{array}{l}\mathrm{BD} \\
\mathrm{MD} \\
\mathrm{PD}\end{array}$ & $\begin{array}{c}7 \\
20 \\
8 \\
\end{array}$ & $\begin{array}{l}20,0 \\
57,1 \\
22,8\end{array}$ \\
\hline Inflamação & $\begin{array}{c}\text { Ausente / Leve } \\
\text { Moderada / Intensa }\end{array}$ & $\begin{array}{l}23 \\
12\end{array}$ & $\begin{array}{l}65,7 \\
34,3\end{array}$ \\
\hline Invasão perineural & $\begin{array}{l}\text { Presente } \\
\text { Ausente } \\
\text { SI }\end{array}$ & $\begin{array}{c}19 \\
15 \\
1 \\
\end{array}$ & $\begin{array}{c}54,3 \\
42,8 \\
2,8 \\
\end{array}$ \\
\hline Metástase confirmada (pNM) & $\begin{array}{c}\text { NOM0 } \\
\text { Metastáticos total } \\
\text { N1 } \\
\text { N2a } \\
\text { N2b } \\
\text { N2c } \\
\text { N3 } \\
\text { M1 } \\
\text { MX }\end{array}$ & $\begin{array}{c}16 \\
19 \\
2 \\
5 \\
7 \\
3 \\
2 \\
4 \\
1 \\
\end{array}$ & $\begin{array}{c}45,7 \\
54,3 \\
5,7 \\
14,3 \\
20,0 \\
8,6 \\
5,7 \\
11,4 \\
2,8 \\
\end{array}$ \\
\hline Extravasamento capsular & $\begin{array}{c}\text { Sim } \\
\text { Não (dentre os metastáticos) }\end{array}$ & $\begin{array}{c}5 \\
14\end{array}$ & $\begin{array}{l}14,3 \\
40,0\end{array}$ \\
\hline Estágio patológico (pTNM) & $\begin{array}{c}\text { Estágio 1 } \\
\text { Estágio } 2 \\
\text { Estágio } 3 \\
\text { Estágio 4 (a, b ou c) }\end{array}$ & $\begin{array}{c}5 \\
7 \\
8 \\
15 \\
\end{array}$ & $\begin{array}{l}14,3 \\
20,0 \\
22,8 \\
42,8 \\
\end{array}$ \\
\hline Recidivas & $\begin{array}{l}\text { Sim } \\
\text { Não }\end{array}$ & $\begin{array}{c}7 \\
28\end{array}$ & $\begin{array}{l}20,0 \\
80,0\end{array}$ \\
\hline $\begin{array}{c}\text { Sobrevida } \\
\text { doença-específica* }\end{array}$ & $\begin{array}{l}\text { Óbitos } \\
\text { Vivos }\end{array}$ & $\begin{array}{l}13 \\
15\end{array}$ & $\begin{array}{l}57,1 \\
42,9\end{array}$ \\
\hline
\end{tabular}

Fonte: Instituto Nacional de Câncer (2007-2009), com fragmentos armazenados no Banco Nacional de Tumores - INCA. SI: Sem informação; BD - bem diferenciado; MD - moderadamente diferenciado; PD - pobremente diferenciado. *7 de óbito não relacionados ao carcinoma epidermoide bucal. 
Segundo os parâmetros utilizados no sistema TNM para CEB, prevaleceram na amostra tumores T2 $(n=18 ; 51,4 \%)$ e T3 $(n=11 ; 31,4 \%)$, ou seja, tumores entre 2 e $4 \mathrm{~cm}$ (T2) e tumores maiores que $4 \mathrm{~cm}$ (T3), respectivamente. Tumores T1, ou menores que $2 \mathrm{~cm}$, representaram 14,3\% $(n=5)$ da amostra, e apenas um caso foi classificado como T4, por invadir profundamente o músculo genioglosso. Todos os casos foram tratados cirurgicamente, sendo empregada a glossopelvectomia ( $n=21 ; 60,0 \%)$, glossectomia ( $n=13 ; 37,1 \%$ ), e um único caso de ressecção de lesão em assoalho sem extensão cirúrgica para língua e/ou mandíbula $(n=1 ; 2,9 \%)$. A grande maioria dos pacientes recebeu esvaziamento cervical, variando entre uni $(n=18 ; 51,4 \%)$ ou bilateral $(n=15 ; 42,8 \%)$.

Utilizando os critérios tradicionais de gradação histológica adotados pela OMS (Cardesa et al., 2005), observamos um predomínio de tumores moderadamente diferenciados ( $n=20 ; 57,1 \%)$. Tumores bem diferenciados representaram $20,0 \%$ da amostra $(n=7)$ e pobremente diferenciados $22,8 \%$ $(n=8)$. Com relação ao infiltrado inflamatório, observou-se $23(65,7)$ casos com infiltrado linfocítico leve ou ausente e $12(34,3)$ casos com infiltrado linfocítico moderado e apenas um caso de infiltrado inflamatório intenso. De todos os casos, apenas seis $(17,1 \%)$ tiveram margens comprometidas após o tratamento cirúrgico, sendo que dois recidivaram. Com relação a outros aspectos histológicos, registrou-se nos laudos histopatológicos a presença de invasão perineural em 14 casos (40,0\%), angiolinfática em 2 (5,7\%) e ambas em $5(14,3 \%)$ casos. Aos cortes, a espessura tumoral mínima observada foi 4 $\mathrm{mm}$ e a máxima $35 \mathrm{~mm}$, dando uma média de $15,4 \mathrm{~mm}( \pm 7,01)$.

A metástase regional foi observada em 19 casos (54,3\%), prevalecendo o padrão N2b $(n=7 ; 20,0 \%)$ e $N 1 \quad(n=5 ; 14,3 \%)$. O extravasamento capsular foi registrado em $5(14,3 \%)$ casos, dos quais apenas 1 não foi a óbito. Metástase à distância foi confirmada histopatologicamente em apenas um caso por meio de exame de lavado brônquico. Apesar disto, houve diagnóstico imaginológico de metástase à distância em outros três casos: dois casos em exame de radiografia de tórax e um caso em cintilografia óssea (metástase em vértebras, íleo e escápula). Considerando o evento metástase como um todo, pode-se dizer que houve $16(45,7 \%)$ casos não metastáticos (NOM0) e 19 (54,3\%) metastáticos. 
A radioterapia do tipo cobaltoterapia foi realizada em $22(74,3 \%)$ casos. Dos pacientes que não receberam radioterapia, todos possuíam tumores de tamanho T1 ou T2 inicialmente, e margens livres no pós-cirúrgico. Quatro tiveram diagnóstico de metástase regional após esvaziamento cervical, e destes, dois recidivaram.

O tempo de acompanhamento médio foi de 31,9 meses $( \pm 20,96)$, variando entre 2,4 a 71,8 meses. Neste período, foram registradas sete $(20 \%)$ recidivas. Para oito pacientes $(22,8 \%)$ foram também registradas a presença de outros tumores (segundo primários): carcinoma de pequenas células em pulmão $(n=1)$, carcinoma epidermoide de laringe $(n=3)$, carcinoma basocelular em região nasal $(n=1)$, adenocarcinoma gástrico $(n=1)$ e adenocarcinoma em endométrio $(n=1)$. Apenas um destes ocorreu previamente ao CEB, constando de um carcinoma epidermoide de laringe de paciente que evolui para óbito.

$57,1 \%(n=20)$ dos pacientes desta amostra tiveram registro de óbito nos arquivos médicos do INCA, sendo $7(20,0 \%)$ não relacionados ao avanço do CEB. O tempo médio de sobrevida dos casos censurados, ou seja, casos sem registro de óbito ou com óbito não relacionados ao CEB, foi de 39,0 $( \pm 20,20)$ meses. A média de sobrevida para casos de óbitos relacionados ao CEB foi de 20,0 $( \pm 16,9)$ meses. Os dados clinicopatológicos classicamente vinculados ao estabelecimento prognóstico foram testados quando à capacidade preditiva de sobrevida para a presente amostra, sendo os mais importantes representados pela figura 5.1. O evento metastático é mundialmente reconhecido como o de maior peso no prognóstico (Cardesa et al., 2005). Na presente amostra observou-se que 52,63\% $(n=10)$ dos casos de CEB metastáticos foram a óbito pela doença. Este número foi bem reduzido quando não houve metástases do $\operatorname{CEB}(n=3 ; 18,75 \%)$. As diferenças observadas margearam significância estatística pelo teste de Mantel-Cox $(p=0,07)$. Os casos metastáticos com extravasamento capsular linfonodal tiveram menor sobrevida, com diferenças margeando significância estatística $(p=0,066)$. Os casos classificados como estágio 4 , conforme 0 pTNM obtido, tiveram sobrevida significantemente reduzida $(p=0,009)$. Observando o tamanho separadamente, nota-se que casos de tumores T3 e T4 tiveram menor sobrevida quando comparado ao grupo formado por casos 
T1 e T2, ou de lesão inicial $(p=0,034)$. Outros fatores, como grau histológico $(p=0,4134)$, recidiva $(p=0,2923)$, pacientes acima de 60 anos $(p=0,8394)$ e invasão perineural $(p=0,2070)$, não mostraram valor prognóstico para a presente amostra.

A)

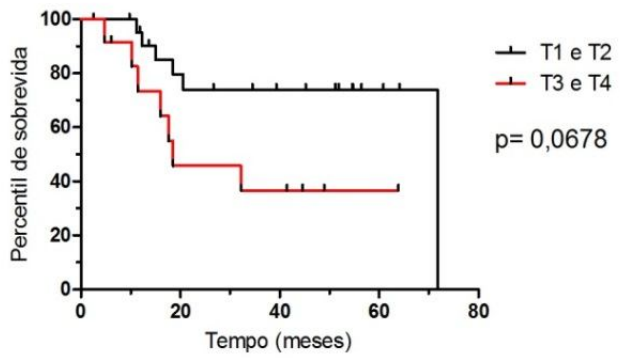

Se

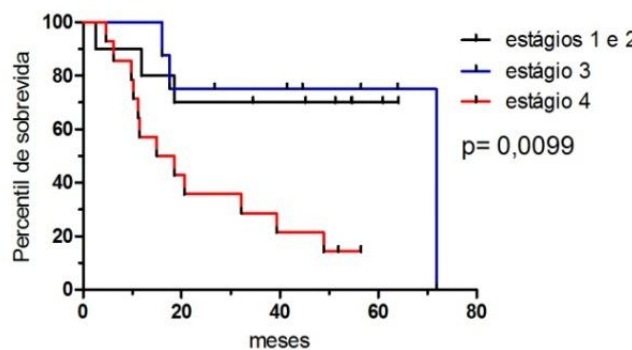

B)

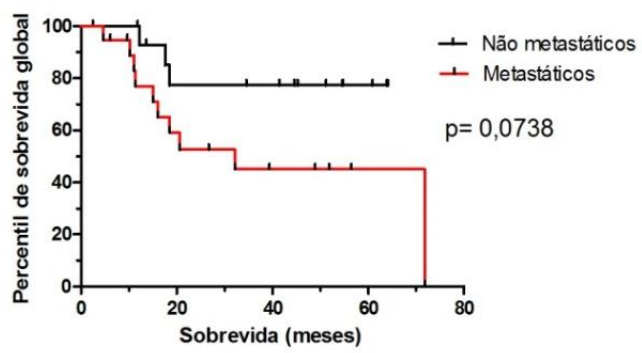

D)

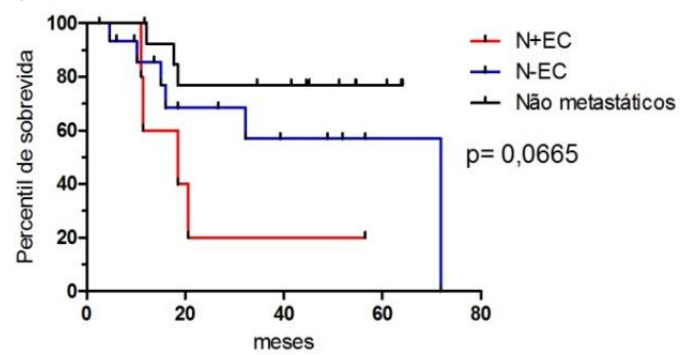

Figura 5.1 - Gráficos de análise de sobrevida segundo parâmetros clínico-patológicos potencialmente relacionados com prognóstico. A) Gráfico dissociando a amostra segundo os parâmetros de T do sistema TNM. B) Gráfico dissociando a amostra segundo o comportamento metastático do CEB (excluídos casos $\mathrm{Nx}$ e casos $\mathrm{Mx}$ ). C) Gráfico dissociando a amostra segundo o evento "extravasamento capsular linfonodal" (EC) em casos com metástase nodal com descrição de EC (N+EC), casos com metástase nodal sem EC (N-EC) e casos não metastáticos 


\subsection{EXPRESSÃO GÊNICA DAS METALOTIONEÍNAS}

A tabela 5.3 descreve a proporção de casos onde foi possível identificar a expressão gênica das diferentes isoformas de MT. Foi possível identificar expressão dos genes MT1A, MT1X e MT2A em todas as amostras de CEB do estudo, bem como para todas as amostras de mucosa oral correspondente (MOC). A expressão dos genes MT1B, MT1E, MT1F, MT1G, MT1H e MT3 foi indetectável em algumas das amostras, destacando-se os genes $M T 1 B$ e $M T 1 H$, onde a expressão foi detectada em apenas um mínimo de casos (Tabela 5.3).

Tabela 5.3 - Relação entre isoformas de Metalotioneína e a proporção de casos onde foi identificada sua expressão dentre os 40 ciclos de RT-qPCR executados

\begin{tabular}{lcc}
\hline \multirow{2}{*}{ Gene } & \multicolumn{2}{c}{ Expressão gênica } \\
\cline { 2 - 3 } & CEB $^{\mathbf{1}}$ & MOC $^{\mathbf{2}}$ \\
\hline MT1A & $100 \%$ & $100 \%$ \\
MT1B & $5,7 \%$ & $0 \%$ \\
MT1F & $100 \%$ & $94,3 \%$ \\
MT1G & $100 \%$ & $94,3 \%$ \\
MT1H & $100 \%$ & $94,3 \%$ \\
MT1X & $11,4 \%$ & $11,4 \%$ \\
MT2A & $100 \%$ & $100 \%$ \\
MT3 & $100 \%$ & $100 \%$ \\
MT4 & $65,7 \%$ & $94,3 \%$ \\
GAPDH & $57,1 \%$ & $80 \%$ \\
& $100 \%$ & $100 \%$ \\
\hline
\end{tabular}

1. Carcinoma epidermoide bucal; 2. mucosa oral correspondente.

\subsubsection{Quantificação da expressão gênica das Metalotioneínas}

A figura 5.2 ilustra a expressão dos genes das MTs em CEB e MOC e a tabela 5.4 relaciona as medianas e variações de expressão para cada tecido. Observa-se que geralmente todos os genes das MTs são de baixa 
expressão em relação ao $G A P D H$, como pode ser visto pela quantidade predominante de casos abaixo do eixo $x$ do gráfico da figura 5.2. Dentre os genes das MTs, destacam-se MT2A, MT1X e MT1G por apresentarem os maiores níveis de expressão em ambos os tecidos, no CEB e na MOC (Tabela 5.4). O gene MT2A teve expressão semelhante ao MT1X no CEB, porém este último destacou-se dentre os genes nas amostras de MOC. Os genes de menor expressão no CEB foram MT3 e MT4 enquanto que nas amostras de MOC foram os genes MT1F e MT4. Seguindo para uma comparação entre a expressão dos genes das MTs no CEB com a expressão dos genes na MOC, observou-se a existência de diferenças significativas com relação ao $\operatorname{MT1A}(\mathrm{p}=0,008), \operatorname{MT1F}(\mathrm{p}=0,0011), \operatorname{MT1X}(\mathrm{p}<0,0001), M T 3$ $(p<0,0001)$ e MT4 $(p=0,0052)$ (Tabela 5.4). Não se observaram diferenças significativas de expressão entre os genes MT1E, MT1G e MT2A comparando CEB e MOC.

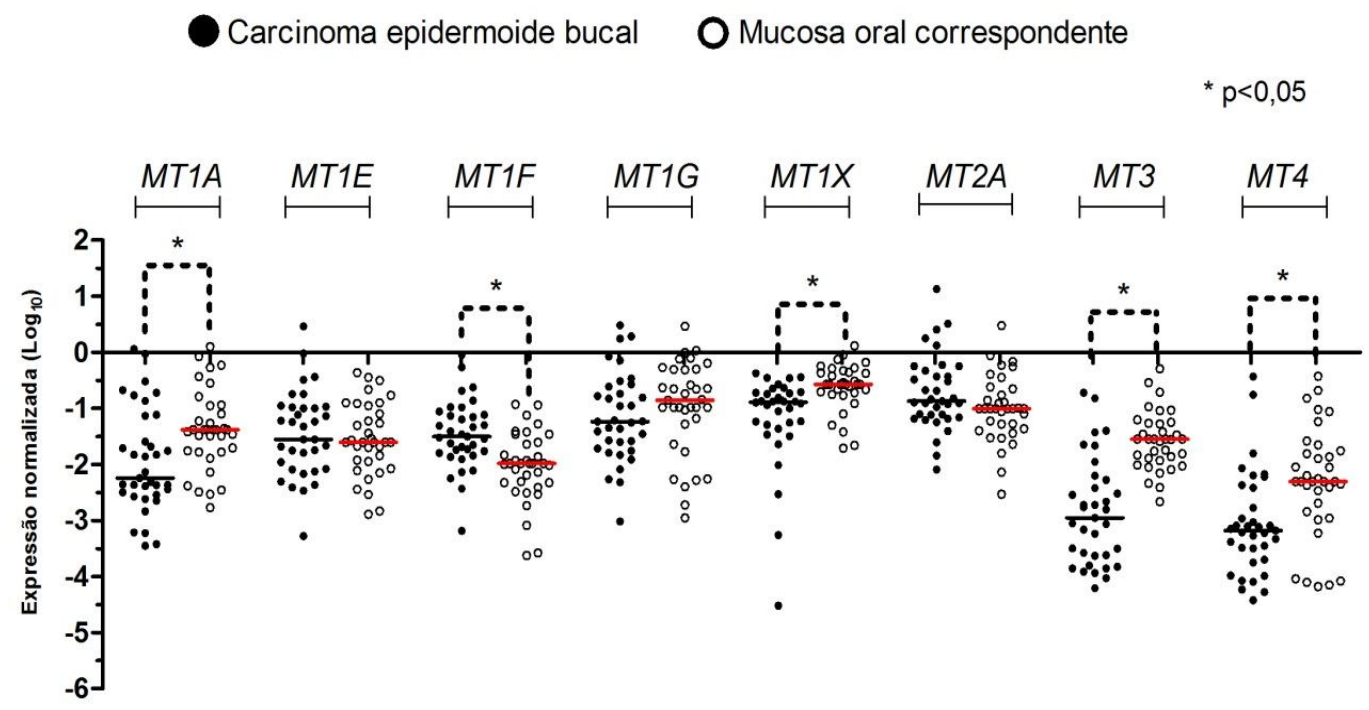

Figura 6 - Expressão dos genes das metalotioneínas em carcinoma epidermoide bucal e na mucosa oral correspondente aos casos. Diferenças significativas são ressaltadas com asterisco $\left({ }^{*}\right)$. A mediana de expressão para mucosa oral correspondente está ressaltada na cor vermelha. A mesma foi utilizada para dividir os tumores em alta e baixa expressão para as análises com relação aos dados clínicopatológicos 
Tabela 5.4 - Valores de mediana, mínimo e máximo de expressão dos genes das metalotioneínas normalizada com o gene constitutivo GAPDH por meio de RTqPCRnos casos de carcinoma epidermoide bucal e amostras da mucosa oral correspondente

\begin{tabular}{lccc}
\hline \hline Gene & CEB $^{1}$ & MOC $^{2}$ & $\boldsymbol{p}^{*}$ \\
\hline MT1A & $0,01(0,0001-0,4)$ & $0,04(0,001-1,26)$ & $\mathbf{0 , 0 0 8}$ \\
\cline { 2 - 4 } MT1E & $0,04(0,00005-2,9)$ & $0,02(0,00005-0,43)$ & 0,4944 \\
\cline { 2 - 4 } MT1F & $0,03(0,00064-0,9)$ & $0,01\left(2,369^{-04}-0,11\right)$ & $\mathbf{0 , 0 0 1 1}$ \\
MT1G & $0,06(0,0009-3,02)$ & $0,13(0,001-2,92)$ & 0,1644 \\
MT1X & $0,13\left(2,99.10^{-05}-0,42\right)$ & $0,26(0,019-1,31)$ & $\mathbf{P}<0,0001$ \\
MT2A & $0,13(0,008-13,51)$ & $0,10(0,002-2,99)$ & 0,1427 \\
\cline { 2 - 4 } MT3 & $0,001(0,00006-0,18)$ & $0,03(0,00005-0,50)$ & $\mathbf{0 , 0 0 0 5}$ \\
nTM & $0,0006(0,00003-0,370)$ & $0,004(0,00006-0,376)$ & $\mathbf{0 , 0 0 5 2}$ \\
\hline
\end{tabular}

* Valor de $\mathrm{p}$ obtido por teste de Wilcoxon. Em negrito valores de $\mathrm{p}$ que demonstram diferenças significativas $(p<0,05)$. 1. Carcinoma epidermoide bucal; 2 . mucosa oral correspondente.

As medianas de MOC de cada gene listadas na tabela anterior foram utilizadas como pontos de corte para dividir os casos de CEB em CEB de alta expressão e CEB de baixa expressão (Tabela 5.5). Seguindo este critério observa-se um predomínio de CEB de alta expressão para MT1E, MT1F e MT2A, e um predomínio de casos de CEB de baixa expressão para MT1G, MT1H (casos de expressão não detectada) MT1X, MT3 e MT4. 
Tabela 5.5 - Relação de casos de carcinoma epidermoide bucal de alta e baixa expressão, determinados a partir da mediana de expressão obtida na mucosa oral correspondente aos casos

\begin{tabular}{lcc}
\hline & $\begin{array}{c}\text { CEB de alta expressão } \\
\text { No. (\%) }\end{array}$ & $\begin{array}{c}\text { CEB de baixa expressão } \\
\text { No. }(\%)\end{array}$ \\
\hline MT1A & $9(25,7)$ & $26(\mathbf{7 4 , 3})$ \\
MT1E & $19(54,3)$ & $16(45,7)$ \\
MT1F & $30(85,7)$ & $5(14,3)$ \\
MT1G & $13(37,1)$ & $22(62,8)$ \\
MT1H $^{\star}$ & $14(40,0)$ & $21(60,0)$ \\
MT1X & $4(11,4)$ & $31(88,6)$ \\
MT2A & $23(65,7)$ & $12(34,3)$ \\
MT3 & $4(11,4)$ & $31(88,6)$ \\
MT4 & $7(20,0)$ & $28(80,0)$ \\
\hline
\end{tabular}

*Para o gene MT1H casos de alta expressão são aqueles onde houve detecção de expressão no qPCR, e os de baixa expressão são aqueles de expressão ausente nos 40 ciclos avaliados.

\subsubsection{Expressão gênica das metalotioneínas no carcinoma epidermoide bucal segundo parâmetros clinico-patológicos}

A fim de traçar o perfil de expressão gênica da MT em relação a dados clínicopatológicos de CEB, múltiplas análises foram realizados confrontando a expressão de cada isoforma de MT com os respectivos achados clínicopatológicos. As principais comparações com relação ao prognóstico, representados por comportamento metastático e análise de sobrevida, são descritas separadamente no subtítulo seguinte.

Analisando as expressões gênicas por comparações entre grupos de CEB divididos pelos critérios clínico-patológicos (teste de Mann-Whitney para dois grupos ou Kruskal-Wallis para mais de dois grupos) observaram-se diferenças estatisticamente significativas apenas para o gene $\operatorname{MT1F}(p=0,02)$ com relação ao tabagismo, margeando significância quando avaliado o mesmo aspecto para o gene MT3 $(p=0,07)$ (Tabela 5.6). Casos de CEB de pacientes tabagistas tiveram mediana 0,0229 para o gene $M T 1 F$, variando de 0,0036 a 0,2069 , enquanto que para pacientes não tabagistas a mediana foi 0,1385 , variando de 0,0287 a 0,9054 . Com relação ao gene $M T 3$, a mediana foi $0,0006\left(9,283.10^{-5}\right.$ a 0,03970$)$ para pacientes tabagistas e $0,0052(0,0002$ a 0,1897$)$ para não tabagistas. Não se observam tais diferenças dentre estes 
grupos quando os casos de CEB foram classificados em alta e baixa expressão para MT1F e MT3 ( $p=1,000$ e $p=0,091$, respectivamente). Todas as outras variáveis (idade, sexo, etilismo, localização, tamanho, grau histológico, inflamação, invasão perineural e recidivas) não separaram grupos com diferenças estatisticamente significantes, nem mesmo quando a amostra foi dividida em casos de alta e baixa expressão, conforme disposto na tabela 5.7 .

Tabela 5.6 - Relação de valores de "p" obtidos após comparação de grupos separados por critérios clínico-patológicos com relação à expressão dos genes das metalotioneínas

\begin{tabular}{|c|c|c|c|c|c|c|c|c|}
\hline Parâmetros & & & Gen & das m & talotio & ínas & & \\
\hline $\begin{array}{l}\text { Clínico- } \\
\text { patológicos }\end{array}$ & MT1A & MT1E & MT1F & MT1G & MT1X & MT2A & MT3 & MT4 \\
\hline $\begin{array}{l}\text { Idade } \\
(35-60 \text { ou } \\
>60)\end{array}$ & 0,33 & 0,91 & 0,40 & 0,88 & 0,54 & 0,17 & 0,43 & 0,88 \\
\hline Sexo & 0,95 & 0,42 & 0,92 & 0,57 & 0,92 & 0,32 & 0,57 & 0,95 \\
\hline Tabagismo & 0,10 & 0,05 & 0,02 & 0,71 & 0,48 & 0,21 & 0,07 & 0,52 \\
\hline Etilismo & 0,06 & 0,13 & 0,25 & 0,66 & 0,40 & 0,16 & 0,13 & 0,95 \\
\hline Localização & 0,55 & 0,42 & 0,13 & 0,47 & 0,10 & 0,40 & 0,34 & 0,29 \\
\hline Tamanho ${ }^{1}$ & 0,46 & 0,09 & 0,30 & 0,90 & 0,75 & 0,81 & 0,46 & 0,34 \\
\hline $\begin{array}{l}\text { Gradação } \\
\text { histológica }\end{array}$ & 0,68 & 1,00 & 0,73 & 0,94 & 0,79 & 0,79 & 1,00 & 0,25 \\
\hline Inflamação & 0,86 & 0,90 & 0,86 & 0,42 & 0,90 & 0,75 & 0,83 & 0,20 \\
\hline $\begin{array}{l}\text { Invasão } \\
\text { perineural }\end{array}$ & 0,25 & 0,85 & 0,94 & 0,36 & 0,76 & 0,51 & 0,16 & 0,62 \\
\hline Recidivas & 0,20 & 0,39 & 0,39 & 0,15 & 0,68 & 0,23 & 0,47 & 0,13 \\
\hline
\end{tabular}


Tabela 5.7 - Relação de casos de alta e baixa expressão gênica das metalotioneínas segundo dados clínico-patológicos

\begin{tabular}{|c|c|c|c|c|c|c|c|c|c|c|c|c|c|c|c|c|c|c|c|c|c|c|c|c|c|c|c|c|}
\hline \multirow{2}{*}{$\begin{array}{l}\text { Achados clinico- } \\
\text { patológicos }\end{array}$} & \multirow{2}{*}{$\begin{array}{l}\text { No. de } \\
\text { casos }\end{array}$} & \multicolumn{2}{|c|}{ MT-1A } & \multirow{2}{*}{ IC } & \multicolumn{2}{|c|}{ MT-1E } & \multirow{2}{*}{ IC } & \multicolumn{2}{|c|}{ MT-1F } & \multirow[b]{2}{*}{ IC } & \multicolumn{2}{|c|}{ MT-1G } & \multirow{2}{*}{ IC } & \multicolumn{2}{|c|}{ MT-1 $\mathrm{H}^{*}$} & \multirow{2}{*}{ IC } & \multicolumn{2}{|c|}{ MT-1X } & \multirow{2}{*}{ IC } & \multicolumn{2}{|c|}{ MT-2A } & \multirow{2}{*}{ IC } & \multicolumn{2}{|c|}{ MT-3 } & \multirow{2}{*}{ IC } & & $T-4$ & \\
\hline & & Alta & Baixa & & Alta & Baixa & & Alta & Baixa & & Alta & Baixa & & + & - & & Alta & Baixa & & Alta & Baixa & & Alta & Baixa & & Alta & Baixa & IC \\
\hline Idade & & & & & & & & & & & & & & & & & & & & & & & & & & & & \\
\hline $35-60$ anos & 20 & 6 & 14 & 00700 & 12 & 8 & 0506 & 17 & 3 & 1000 & 6 & 14 & 0,481 & 10 & 10 & م 206 & 4 & 16 & 0126 & 12 & 8 & 0180 & 3 & 17 & 0610 & 4 & 16 & 1000 \\
\hline $\begin{array}{l}>60 \text { anos } \\
\text { Sexo }\end{array}$ & 15 & 3 & 12 & 0,700 & 7 & 8 & , 506 & 13 & 2 &,, 000 & 7 & 8 & & 4 & 11 & 0,296 & 0 & 15 & 0,126 & 11 & 4 & 0,489 & 1 & 14 & 0,619 & 3 & 12 & 1,000 \\
\hline Masculino & 27 & 8 & 19 & 0,648 & 15 & 12 & 1,000 & 23 & 4 & 1,000 & 12 & 15 & 0.211 & 12 & 15 & 0,431 & 4 & 23 & 0,553 & 19 & 8 & 0,402 & 3 & 24 & 1,000 & 5 & 22 & 0,648 \\
\hline Feminino & 8 & 1 & 7 & & 4 & 4 & & 7 & 1 & & 1 & 7 & $0, \angle T I$ & 2 & 6 & & 0 & 8 & & 4 & 4 & & 1 & 7 & & 2 & 6 & \\
\hline Tabagismo $^{1}$ & & & & & & & & & & & & & & & & & & & & & & & & & & & & \\
\hline Sim & 20 & 3 & 17 & 0,252 & 11 & 9 & 0,123 & 18 & 2 & 1,000 & 7 & 13 & 1,000 & 6 & 14 & 0,680 & 1 & 19 & 1,000 & 13 & 7 & 1,000 & 1 & 19 & 0,091 & 4 & 16 & 0,341 \\
\hline Não & 5 & 2 & 3 & & 5 & 0 & & 5 & 0 & & 1 & 4 & & 2 & 3 & & 0 & 5 & & 3 & 2 & & 2 & 3 & & 3 & 2 & \\
\hline Etilismo $^{1}$ & & & & & & & & & & & & & & & & & & & & & & & & & & & & \\
\hline Sim & 17 & 3 & 13 & 0,621 & 9 & 8 & 0,191 & 16 & 1 & 0,507 & 6 & 11 & 1,000 & 7 & 10 & 0,669 & 1 & 16 & 1,000 & 10 & 7 & 0,669 & 1 & 16 & 0,194 & 4 & 13 & 0,113 \\
\hline Não & 7 & 2 & 5 & & 6 & 1 & & 6 & 1 & & 2 & 5 & & 2 & 5 & & 0 & 7 & & 5 & 2 & & 2 & 5 & & 3 & 4 & \\
\hline Local. do tumor & & & & & & & & & & & & & & & & & & & & & & & & & & & & \\
\hline Língua & 19 & 4 & 15 & & 12 & 7 & & 17 & 0 & & 8 & 11 & & 9 & 10 & & 3 & 16 & & 14 & 5 & & 1 & 18 & & 4 & 15 & \\
\hline Língua/assoalho & 8 & 3 & 5 & 0,670 & 4 & 4 & 0,456 & 6 & 2 & 0,119 & 4 & 4 & 0,241 & 4 & 4 & 0,194 & 1 & 7 & 0,497 & 5 & 3 & 0,485 & 2 & 6 & 0,337 & 2 & 6 & 0,811 \\
\hline Assoalho & 8 & 2 & 6 & & 3 & 5 & & 7 & 1 & & 1 & 7 & & 1 & 7 & & 0 & 8 & & 4 & 4 & & 1 & 7 & & 1 & 7 & \\
\hline Dimensão clínica & & & & & & & & & & & & & & & & & & & & & & & & & & & & \\
\hline $\mathrm{T} 1$ e T2 & 23 & 6 & 17 & 1,000 & 15 & 8 & 0,090 & 21 & 2 & 0,313 & 9 & 14 & 1,000 & 9 & 14 & $, 70,884$ & 3 & 20 & 1,000 & 14 & 9 & 0,477 & 2 & 21 & 0,594 & 5 & 18 & 1,000 \\
\hline T3 е T4 & 12 & 3 & 9 & 1,000 & 4 & 8 & 0,090 & 9 & 3 & 0,315 & 4 & 8 & 1,000 & 5 & 7 & $, 0,884$ & 1 & 11 & 1,000 & 9 & 3 & $0,4 \pi / 7$ & 2 & 10 & & 2 & 10 & 1,000 \\
\hline Grau histopatológico & & & & & & & & & & & & & & & & & & & & & & & & & & & & \\
\hline Bem diferenciado & 7 & 3 & 4 & & 3 & 4 & & 6 & 1 & & 3 & 4 & & 9 & 10 & & 1 & 6 & & 5 & 2 & & 1 & 6 & & 3 & 4 & \\
\hline Mod. diferenciado & 20 & 4 & 16 & 0,491 & 11 & 9 & 0,745 & 17 & 3 & 0,986 & 7 & 13 & 0,934 & 4 & 4 & 0,194 & 1 & 19 & 0,312 & 14 & 6 & 0,565 & 2 & 18 & 0,949 & 4 & 16 & 0,117 \\
\hline Pob. Diferenciado & 8 & 2 & 6 & & 5 & 3 & & 7 & 1 & & 3 & 5 & & 1 & 7 & & 2 & 6 & & 4 & 4 & & 1 & 7 & & 0 & 8 & \\
\hline Inflamação & & & & & & & & & & & & & & & & & & & & & & & & & & & & \\
\hline Ausente/leve & 23 & 6 & 17 & 1.000 & 11 & 12 & 0,476 & 19 & 4 & 0,640 & 10 & 13 & 0,463 & 8 & 15 & 0,383 & 3 & 19 & 1.000 & 16 & 7 & 0,709 & 2 & 21 & 0,594 & 6 & 17 & 0,380 \\
\hline Moderada/intensa & 12 & 3 & 9 & 1,000 & 8 & 4 & 0,470 & 11 & 1 & $0,0+0$ & 3 & 9 & & 6 & 6 & & 1 & 11 & , , & 7 & 5 & & 2 & 10 & 0,004 & 1 & 11 & 0,000 \\
\hline Invasão perineural $^{1}$ & & & & & & & & & & & & & & & & & & & & & & & & & & & & \\
\hline Presente & 19 & 7 & 12 & 0,240 & 11 & 8 & 0,730 & 16 & 3 & 1,000 & 6 & 13 & 0,724 & 6 & 13 & 0,369 & 2 & 17 & 1,000 & 12 & 7 & 1,000 & 2 & 17 & 1,000 & 5 & 14 & 0,426 \\
\hline Ausente & 15 & 2 & 13 & & 7 & 8 & & 13 & 2 & & 6 & 9 & & 7 & 8 & & 1 & 13 & & 10 & 5 & & 2 & 13 & & 2 & 13 & \\
\hline Recidiva & & & & & & & & & & & & & & & & & & & & & & & & & & & & \\
\hline Presente & 7 & 2 & 5 & 1.000 & 4 & 3 & 1000 & 2 & 1 & 0,319 & 1 & 6 & 0.210 & 1 & 6 & 0,220 & 0 & 7 & 0.559 & 5 & 2 & 1.000 & 2 & 5 & 0.171 & 0 & 7 & \\
\hline Ausente & 28 & 7 & 21 & 1,000 & 15 & 8 & 1,000 & 21 & 2 & 0,319 & 12 & 15 & 0,210 & 12 & 16 & 0,220 & 4 & 23 & 0,559 & 18 & 10 & 1,000 & 2 & 26 & $0,1 / 1$ & 7 & 21 & 0,301 \\
\hline
\end{tabular}




\subsubsection{Expressão gênica das metalotioneínas em carcinoma epidermoide bucal segundo o comportamento metastático tumoral}

Observaram-se maiores medianas de expressão para a maioria dos genes das metalotioneínas considerando o evento metástase (Tabela 5.8). A partir do teste de comparação de Mann-Whitney, observou-se diferença estatisticamente significante com relação ao gene $M T 3$, e resultado margeando diferença significativa para MT1A. Casos metastáticos apresentam maiores níveis de expressão de MT1A e MT3 quando comparados com casos não metastáticos. Em todos os demais genes avaliados, foi observado maior expressão nos casos metastáticos, porém sem significância estatística.

Tabela 5.8 - Expressão das isoformas de metalotioneína segundo o comportamento metastático do carcinoma epidermoide bucal

\begin{tabular}{|c|c|c|c|}
\hline Gene & $\begin{array}{c}\text { Metastáticos } \\
\text { Mediana (min-max) }\end{array}$ & $\begin{array}{l}\text { Não metastáticos } \\
\text { Mediana (min-max) }\end{array}$ & IC 95\%* \\
\hline MT1A & $0,0175(0,0022-1,14)$ & $0,0042(0,0003-0,93)$ & 0,0711 \\
\hline MT1E & $\mathbf{0 , 0 4 7 6}\left(9,865.10^{-9}-2,908\right)$ & $0,0280(0,0038-0,32)$ & 0,6549 \\
\hline MT1F & $\mathbf{0 , 0 3 4 5}(0,0036-0,9054)$ & $0,0295(0,0006-0,54)$ & 0,4765 \\
\hline MT1G & $0,0431(0,0009-1,93)$ & $\mathbf{0 , 1 3 3 1}(0,0054-3,020)$ & 0,1236 \\
\hline MT1X & $\mathbf{0 , 1 3 2 0}(0,0005-0,26)$ & $0,1215\left(2,99.10^{-5}-0,42\right)$ & 0,8623 \\
\hline MT2A & $\mathbf{0 , 2 1 0 5}(0,0081-13,51)$ & $0,1292(0,0143-0,59)$ & 0,3287 \\
\hline MT3 & $0,0017(0,0001-0,18)$ & $0,0004\left(6,19 \cdot 10^{-5}-0,02\right)$ & 0,0355 \\
\hline MT4 & $0,0006\left(3,784.10^{-5}-0,37\right)$ & $0,0005\left(5,27.10^{-5}-0,0067\right)$ & 0,3625 \\
\hline
\end{tabular}

teste de Mann-Whitney.

A figura 5.3 mostra por meio de gráfico de dispersão os valores de expressão gênica das MTs no CEB para casos metastáticos e casos não metastáticos. Observam-se casos acima e abaixo do limite delimitado pela mediana da MOC para ambos os casos de CEB, metastáticos e não metastáticos. Entretanto, especificamente para MT1X e MT3, observa-se que o traço desta mediana da MOC delimita casos específicos. Para MT1X não existem casos metastáticos acima da linha. Inversamente, para MT3 não existem casos não metastáticos acima da linha. 
A análise estatística dos dados separando o CEB em alta ou baixa expressão pode ser observada na tabela 5.9 .

- Tumores metastáticos $\quad$ Tumores não metastáticos

${ }^{*} p<0,05$

- Mediana MOC

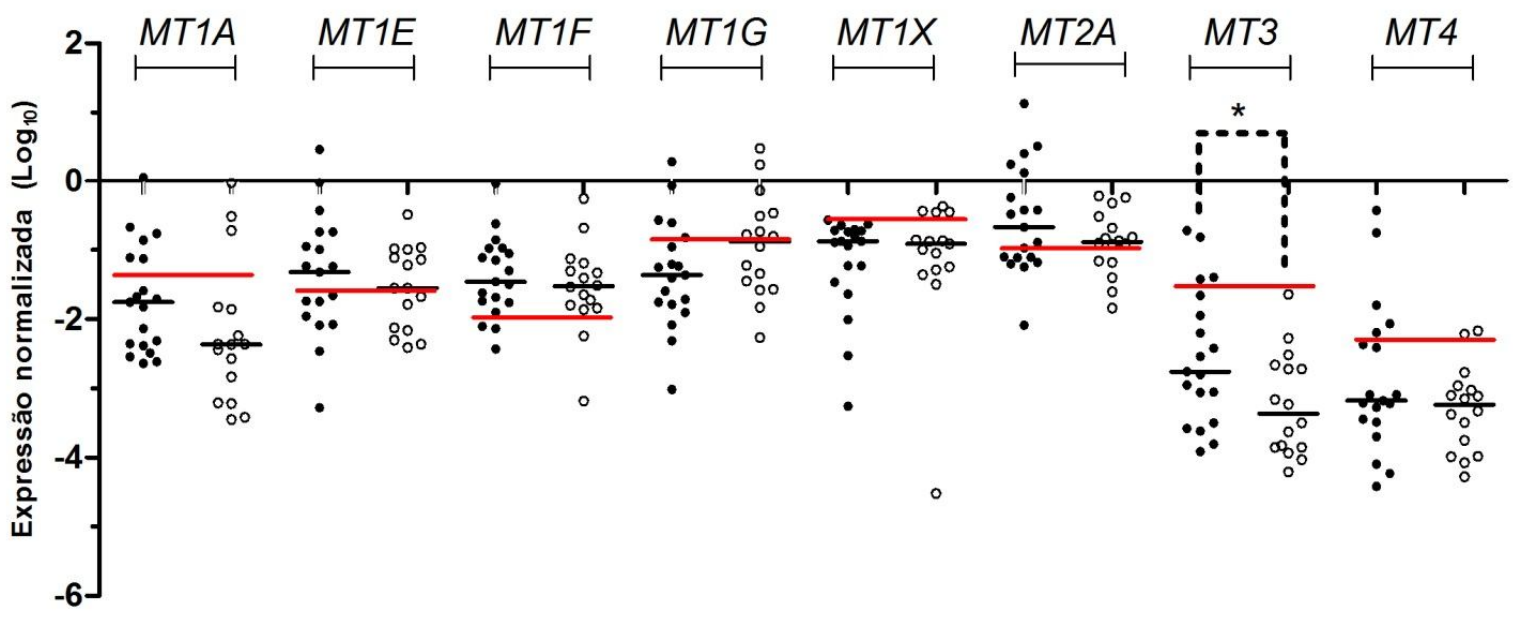

Figura 5.3 - Expressão gênica das metalotioneínas segundo o comportamento metastático do carcinoma epidermoide bucal. Diferenças significativas estão marcadas com asterisco (*). A mediana de expressão obtida para a mucosa oral correspondente aos casos (MOC) está ressaltada em vermelho, pois divide os tumores em alta e baixa expressão

Conforme pode ser observado na tabela 5.9, não há casos de CEB metastático de alta expressão para o gene $\operatorname{MT} 1 X(p=0,0294)$. De forma contrária, observa-se que todos os casos de alta expressão de MT3 são metastáticos, porém estas diferenças não foram estatisticamente significantes $(p=0,1088)$. Nenhuma outra diferença significante foi observada, embora também se destaquem maior número de casos metastáticos de alta expressão para $M T 1 A(17,1 \%$ vs $8,5 \%$; $\mathrm{p}=$ $0,4605)$ e MT4 (14,3\% vs 5,7\%; $p=0,415)$, e casos metastáticos de baixa expressão para MT1G (40,0\% vs 22,8\%; $p=0,1789)$ e $M T 2 A(20,0 \%$ vs $14,3 \%, p=1,0000)$. Para os outros genes a distribuição parece mais uniforme (Tabela 5.9 e Figura 5.3). 
Tabela 5.9 - Expressão gênica da MT em tumores metastáticos e não metastáticos, divididos segundo a mediana de expressão das isoformas em grupos de tumores de maior expressão e tumores de menor expressão

\begin{tabular}{|c|c|c|c|c|}
\hline & Gene & $\begin{array}{l}\text { Metastáticos } \\
\text { No. (\%) }\end{array}$ & $\begin{array}{l}\text { Não metastáticos } \\
\text { No. (\%) }\end{array}$ & $\begin{array}{c}\mathrm{IC} \\
95 \% *\end{array}$ \\
\hline \multirow[t]{2}{*}{ MT1A } & CEB de alta expressão & $6(17,1)$ & $3(8,5)$ & 0,4605 \\
\hline & CEB de baixa expressão & $13(37,1)$ & $13(37,1)$ & \\
\hline \multirow{2}{*}{ MT1E } & CEB de alta expressão & $10(28,5)$ & $9(25,7)$ & 0,3179 \\
\hline & CEB de baixa expressão & $9(25,7)$ & $7(20,0)$ & \\
\hline \multirow[t]{2}{*}{ MT1F } & CEB de alta expressão & $16(45,7)$ & $14(40,0)$ & 1,0000 \\
\hline & CEB de baixa expressão & $3(8,6)$ & $2(5,7)$ & \\
\hline \multirow{2}{*}{ MT1G } & CEB de alta expressão & $5(14,3)$ & $8(22,8)$ & 0,1789 \\
\hline & CEB de baixa expressão & $14(40,0)$ & $8(22,8)$ & \\
\hline \multirow[t]{2}{*}{$M T 1 H^{*}$} & CEB expressão positiva & $8(22,8)$ & $6(17,1)$ & 0,7817 \\
\hline & CEB sem expressão & $11(31,4)$ & $10(28,5)$ & \\
\hline \multirow{2}{*}{ MT1X } & CEB de alta expressão & $0(0)$ & $4(11,4)$ & 0,0294 \\
\hline & CEB de baixa expressão & $19(54,3)$ & $11(31,4)$ & \\
\hline \multirow[t]{2}{*}{ MT2A } & CEB de alta expressão & $12(34,3)$ & $11(31,4)$ & 1,0000 \\
\hline & CEB de baixa expressão & $7(20,0)$ & $5(14,3)$ & \\
\hline \multirow[t]{2}{*}{ MT3 } & CEB de alta expressão & $4(11,4)$ & $0(0)$ & 0,1088 \\
\hline & CEB de baixa expressão & $15(42,8)$ & $17(48,6)$ & \\
\hline \multirow[t]{2}{*}{ MT4 } & CEB de alta expressão & $5(14,3)$ & $2(5,7)$ & 0,415 \\
\hline & CEB de baixa expressão & $14(40,0)$ & $14(40,0)$ & \\
\hline
\end{tabular}

O teste exato de Fisher foi utilizado para os cálculos. *Para o gene MT1H casos de expressão são aqueles onde houve detecção de expressão no qPCR, e os de baixa expressão são aqueles de expressão ausente nos 40 ciclos.

Com relação ao acometimento metastático regional, também foram registrados casos de extravasamento capsular metastático. Nenhuma diferença estatisticamente significante ou até mesmo virtualmente desproporcional foi observada comparando a expressão gênica das MTs dentre casos metastáticos com extravasamento capsular e casos metastáticos sem extravasamento capsular.

A fim de avaliar a influência de outras características de agressividade tumoral incluindo o comportamento metastático, os casos foram classificados em estágios segundo o pTNM. Neste sentido, diferenças significativas foram observadas com relação à expressão do gene $M T 3(p=0,049)$, onde todos os casos de alta expressão foram classificados como estágio 4. Observa-se ainda que casos de baixa expressão para $M T 1 G$ são frequentemente tumores de estágio 4, porém as diferenças não são estatisticamente significantes. Para os outros genes as diferenças não foram significativas (Tabela 5.10). 
Tabela 5.10 - Expressão gênica da MT em tumores metastáticos e não metastáticos, divididos segundo a mediana de expressão das isoformas em grupos de tumores de maior expressão e tumores de menor expressão

\begin{tabular}{|c|c|c|c|c|c|}
\hline & \multirow{2}{*}{ Gene } & \multicolumn{4}{|c|}{ Estágios segundo pTNM } \\
\hline & & $\begin{array}{c}1 \text { e } 2 \\
\text { No. (\%) }\end{array}$ & $\begin{array}{c}3 \\
\text { No. (\%) }\end{array}$ & $\begin{array}{c}4 \\
\text { No. (\%) }\end{array}$ & $\begin{array}{c}\text { IC } \\
95 \%\end{array}$ \\
\hline \multirow[t]{2}{*}{ MT1A } & CEB de alta expressão & $2(5,7)$ & $3(8,5)$ & $4(11,4)$ & 0,576 \\
\hline & CEB de baixa expressão & $10(28,5)$ & $5(14,3)$ & $11(31,4)$ & \\
\hline \multirow[t]{2}{*}{ MT1E } & CEB de alta expressão & $8(22,8)$ & $2(5,7)$ & $9(25,7)$ & 0,157 \\
\hline & CEB de baixa expressão & $4(11,4)$ & $6(17,1)$ & $6(17,1)$ & \\
\hline \multirow[t]{2}{*}{ MT1F } & CEB de alta expressão & $12(34,3)$ & $5(14,3)$ & $13(37,1)$ & 0,063 \\
\hline & CEB de baixa expressão & $0(0)$ & $3(8,5)$ & $2(5,7)$ & \\
\hline \multirow[t]{2}{*}{ MT1G } & CEB de alta expressão & $6(17,1)$ & $3(8,5)$ & $4(11,4)$ & 0,460 \\
\hline & CEB de baixa expressão & $6(17,1)$ & $5(14,3)$ & $11(31,4)$ & \\
\hline \multirow[t]{2}{*}{$M T 1 H^{*}$} & CEB expressão positiva & $5(14,3)$ & $2(5,7)$ & $7(20,0)$ & 0,594 \\
\hline & CEB sem expressão & $7(20,0)$ & $6(17,1)$ & $8(22,8)$ & \\
\hline \multirow{2}{*}{ MT1X } & CEB de alta expressão & $2(5,7)$ & $1(2,8)$ & $1(2,8)$ & 0,715 \\
\hline & CEB de baixa expressão & $10(28,5)$ & $7(20,0)$ & $14(40,0)$ & \\
\hline \multirow[t]{2}{*}{ MT2A } & CEB de alta expressão & $8(22,8)$ & $6(17,1)$ & $9(25,7)$ & 0,768 \\
\hline & CEB de baixa expressão & $4(11,4)$ & $2(5,7)$ & $6(17,1)$ & \\
\hline \multirow[t]{2}{*}{ MT3 } & CEB de alta expressão & $0(0)$ & $0(0)$ & $4(11,4)$ & $\underline{0,049}$ \\
\hline & CEB de baixa expressão & $12(34,3)$ & $8(22,8)$ & $11(31,4)$ & \\
\hline \multirow[t]{2}{*}{ MT4 } & CEB de alta expressão & $2(5,7)$ & $1(2,8)$ & $4(11,4)$ & 0,677 \\
\hline & CEB de baixa expressão & $10(28,5)$ & $7(20,0)$ & $11(31,4)$ & \\
\hline
\end{tabular}

O teste qui-quadrado foi utilizado para os cálculos. *Para o gene MT1H casos de expressão são aqueles onde houve detecção de expressão no qPCR, e os de baixa expressão são aqueles de expressão ausente nos 40 ciclos.

\subsubsection{Expressão gênica das Metalotioneína em Carcinoma Epidermoide Bucal segundo a sobrevida dos pacientes}

A fim de determinar se a expressão gênica das MTs pode fornecer informações sobre a sobrevida dos pacientes, todos os genes foram testados pelo teste de Mantel-Cox considerando casos de alta e baixa expressão. Os valores de "p" relativos aos testes são relacionados na tabela 5.11. Observaram-se diferenças significantes apenas em relação à expressão do $M T 1 G$, sendo que pacientes com baixa expressão de $M T 1 G$ tiveram sobrevida de $50 \%$, enquanto que pacientes com alta expressão de $M T 1 G$ tiveram sobrevida de $84,6 \%(p=0,04)$ (Figura 5.4). 
Tabela 5.11 - Relação dos valores de "p" obtidos após análise de Mantel-Cox com relação à expressão gênica das metalotioneínas e a sobrevida dos pacientes, comparando casos de carcinoma epidermoide de alta expressão com os casos de baixa expressão

\begin{tabular}{lcccccccc}
\hline \hline Sobrevida & MT1A & MT1E & MT1F & MT1G & MT1X & MT2A & MT3 & MT4 \\
\hline Global & 0,3009 & 0,327 & 0,9179 & 0,0967 & 0,3758 & 0,1616 & 0,7583 & 0,6677 \\
$\begin{array}{l}\text { Relacionada } \\
\text { a Causa* }\end{array}$ & 0,2286 & 0,2757 & 0,4951 & $\underline{\mathbf{0 , 0 4 2 9}}$ & 0,149 & 0,1731 & 0,8345 & 0,6638 \\
$\begin{array}{l}\text { * Sete casos foram censurados por óbitos relacionados a outras doenças sem relação direta ou indireta com o } \\
\text { CEB. }\end{array}$
\end{tabular}

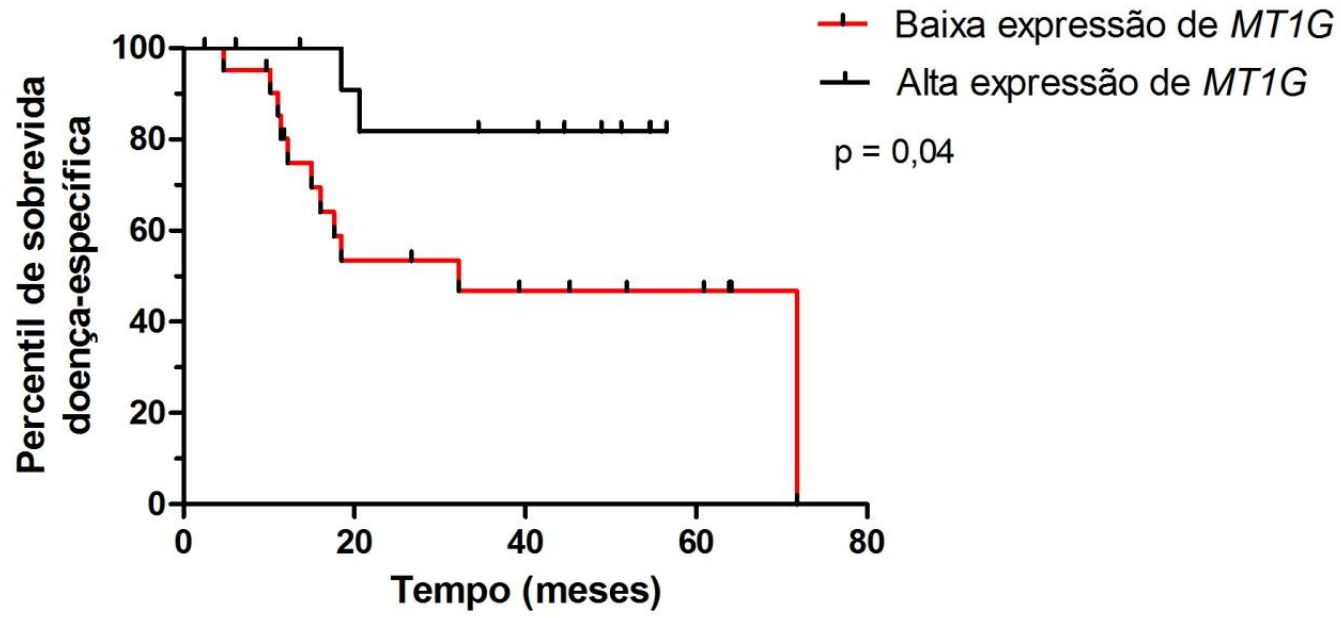

Figura 5.4. Análise de sobrevida entre casos de carcinoma epidermoide de alta expressão e casos de baixa expressão para o gene $M T l G$ 


\section{DISCUSSÃo}

O CEB é um tumor maligno geralmente agressivo que representa no panorama mundial cerca de $5 \%$ dos cânceres em homens e $2 \%$ dos cânceres em mulheres (Johnson et al., 2005). Esta importância epidemiológica associada ao fato de que a cura geralmente tem sido observada para apenas $50 \%$ dos casos faz com que muitos pesquisadores se ocupem na tentativa de identificar marcadores de prognóstico mais precisos e alternativas de conduta terapêutica. Mesmo assim, estes índices de sobrevida se mantêm minimamente modificado ao longo dos anos, mesmo havendo nítidos avanços nas áreas da cirurgia, radioterapia e quimioterapia adjuvante, e em técnicas de imagem e diagnóstico (Ribeiro et al., 2000; Yeole et al., 2000). Dentre as causas que dificultam uma melhoria desta sobrevida para o CEB, pode-se citar a limitação imposta pelas tomadas de prognóstico e decisões terapêuticas restritas à análise do sistema TNM e da gradação histológica. Como sabido, tais ferramentas tem grande importância, porém, são carregadas de subjetividade e limitadas a aspectos morfológicos, com pouca visibilidade fisiopatológica. Desta forma, estudos que favorecem o entendimento sobre a natureza biológica do CEB são muito relevantes, visto que podem auxiliar na identificação da heterogeneidade de agressividade tumoral observada em casos de TNM e gradação histológica idênticos (Yeole et al., 2000). Além disso, a identificação destes fatores pode subsidiar pesquisas focadas na criação de terapias alvo-moleculares. Atualmente, os pacientes que sobrevivem ao tratamento do CEB frequentemente experimentam sequelas mórbidas deixadas pelo tratamento como dano estético e funcional dado pela mutilação cirúrgica, dificuldades de fonação, paladar, mastigação, salivação, etc (Jackson et al., 1999; Ribeiro et al., 2000). Por esta razão, nas últimas décadas e nos dias atuais um esforço significativo tem sido dado na busca destes marcadores biológicos para o CEB (Schliephake 2003; Shintani et al., 2004; Warburton et al., 2007; Miyahara et al., 2007; Bock et al., 2008; Huber et al., 2011; Zhao et al., 2011; Oliveira; Ribeiro-Silva, 2011; Sousa et al., 2012; Lim et al., 2012).

A amostra utilizada neste trabalho incluiu apenas casos de CEB de origem em língua e/ou assoalho bucal, pois são as localizações anatômicas intra-bucais mais frequentemente acometidas pelo CEB (Kolker et al., 2007). Além disso, o CEB 
lingual é geralmente mais agressivo do que os carcinomas epidermoides de orofaringe, laringe, hipofaringe, e outras localizações intra-bucais (Rusthoven et al., 2008). Casos de lesões em base de língua foram excluídos porque são considerados casos de orofaringe. Nestes casos um componente etiológico viral tem sido descrito com maior peso dentre os fatores de risco, especialmente associado ao HPV-16, representando casos de comportamento biológico distinto e prognóstico relativamente favorável (Kreimer et al., 2005; Feller et al., 2010). A amostra deste estudo é, neste sentido, uma amostra de conveniência, que busca avaliar os casos de CEB de localizações mais comuns. Não observamos diferenças de expressão de nenhuma das isoformas das MTs com relação à localização quando comparamos casos de CEB de língua, casos envolvendo língua e assoalho simultaneamente e casos de CEB envolvendo apenas assoalho bucal.

O presente trabalho representa o primeiro estudo que avalia a expressão gênica das MTs no CEB. Atualmente, esta é a melhor forma de estudo diferencial das isoformas das MTs, pois ao nível proteico as MTs são de difícil detecção devido ao seu baixo peso molecular, ou são muito semelhantes para desenvolvimento de anticorpos específicos. A grande maioria dos trabalhos de avaliação proteica das MTs utiliza um anticorpo que é incapaz de distinguir suas isoformas proteicas e se estão na forma livre de metais (apo-MT) ou na forma ligada a metais (holo-MT), teoricamente evidenciando MT1 e MT2 sem distinção (MT1/2). Observou-se no presente estudo que há diferenças significativas de expressão dentre os genes das MTs comparando o CEB com a MOC. Identificou-se um aumento significativo de expressão gênica do gene $M T 1 F$ acompanhado de um aumento não significativo de MT2A. Todos os demais genes apresentaram queda de expressão, com diferenças significativas para os genes MT1A, MT1X, MT3. Desta forma, parece haver uma queda de expressão gênica das MTs como um todo comparando o CEB com a MOC, que é um tecido morfologicamente normal. Houve predomínio de casos de CEB de baixa expressão para 5 genes das MTs (MT1G, MT1H (casos de expressão não detectada) $M T 1 X, M T 3$ e MT4), contra um predomínio de CEB de alta expressão para apenas 3 genes (MT1E, MT1F e MT2A). Com relação às associações clínicas, observou-se relação entre menor expressão de $M T 1 F$ e tabagismo. Com relação a fatores associados com prognóstico, destaca-se a ausência de casos metastáticos com alta expressão de $M T 1 X$, a maior proporção de casos de alta expressão de MT3 no estágio avançado do pTNM, e a associação 
significativa com queda de sobrevida para os casos de CEB de baixa expressão de MT1G. Nenhuma diferença entre CEB e MOC, com dados clínico-patológicos ou com dados relacionados ao prognóstico foi encontrada considerando os genes MT1A, MT1E, e MT2A.

O qPCR é um método extremamente utilizado para análise e quantificação de expressão gênica em biologia molecular. A principal vantagem deste método sob o PCR convencional é sua alta sensibilidade, acurácia e habilidade em identificar transcritos de genes de baixa expressão e pequenas alterações desta expressão (Pfaffl, 2001; Yuan et al., 2006). Duas tecnologias tem sido utilizadas no qPCR, a SYBR ${ }^{\circledR}$ Green e a TaqMan ${ }^{\circledR}$. A diferença básica dentre as duas está no método de inserção do fluoróforo que emite a luz captada pelo aparelho de qPCR para a identificação da transcrição gênica. Na tecnologia TaqMan ${ }^{\circledR}$ o fluoróforo de detecção da transcrição gênica não é um mero intercalante que está em contato direto com os nucleotídeos como no SYBRß Green. Nesta tecnologia o fluoróforo fica preso a uma sonda de nucleotídeos específicos para o gene em estudo. O fluoróforo somente é liberado se ocorrer hibridização do primer e da sonda, garantindo assim maior especificidade ao ensaio (https://www.lifetechnologies.com/br). Este benefício pode ser crucial em casos onde o desenho de um primer altamente sensível não é possível, como é o caso dos genes das MTs, que possuem alta homologia de sequência. Além disso, existem outros benefícios no uso de $\operatorname{TaqMan}^{\circledR}{ }^{\circledR}$ como a maior eficiência das reações, facilidade de padronização de reações e maior reprodutibilidade principalmente quando é um ensaio comercial desenhado pela Applied Biosystems, como foi o caso das sondas e primers deste estudo.

Diversos métodos têm sido utilizados para a quantificação relativa da expressão gênica, dentre eles inclui-se o método da curva padrão, o método da eficiência calibrada e o método do $\Delta \Delta$ Ct. Um estudo recente comparou os resultados obtidos a partir dos três métodos e verificou grande semelhança dentre os mesmos, com discreta vantagem para o método da curva padrão, que foi utilizado no presente estudo, por considerar pequenas diferenças de expressão gênica em relação ao $\Delta \Delta \mathrm{Ct}$ (Bolha et al., 2012). Existem ainda variações na literatura com relação à definição do que serão casos de alta expressão e casos de baixa expressão. Parece haver um consenso com relação ao uso de medianas. Alguns autores utilizam a mediana dos valores dados pela razão entre tecido tumoral e tecido aparentemente normal, ou fold-change, como descrito em literatura inglesa (Werynska et al., 2013). 
Outros preferem utilizar a mediana da expressão obtida analisando os fragmentos tumorais isoladamente (Rodini et al., 2012). No presente estudo foi utilizada a mediana do tecido normal para a determinação deste corte, ou seja, a mediana da expressão obtida para MOC. Foi considerada esta mediana, pois um dos objetivos deste trabalho foi avaliar se há queda ou aumento de expressão no CEB em relação à MOC. Assim, esta mediana representaria uma maior proximidade do que seria obtido num tecido não neoplásico de fato. Logicamente que deve ser considerando que esta é uma limitação do presente estudo, pois segundo os conceitos de cancerização de área este tecido não representa necessariamente o que ocorre na normalidade (Slaughter et al., 1953). Para um próximo estudo talvez seja interessante acrescentar amostras de pacientes sem fatores de risco e histórico de CEB.

Os resultados de expressão gênica das MTs obtidos para o CEB são confrontantes com os trabalhos anteriores que avaliaram a expressão proteica MT1/2, pois mostra frequente queda de expressão em comparação com a MOC. Alguns dos estudos mostraram que a expressão proteica MT1/2 é maior nas displasias epiteliais severas quando comparadas com as mais discretas, sendo ambas maiores do que a expressão observada no tecido aparentemente normal (Johann et al., 2008; Pontes et al., 2009). Desta forma, tem-se a impressão de que a expressão proteica das MTs aumenta no decorrer do processo neoplásico. Por outro lado, não houve associação com grau histológico em nenhum dos estudos com CEB (Muramatsu et al., 2000; Cardoso et al., 2002; Lee et al., 2008; Szelachowska et al., 2008; Szelachowska et al., 2009; Cardoso et al., 2009). Os trabalhos que analisaram o CEB não quantificaram a expressão proteica MT1/2, não avaliaram diferenças de intensidade da imunomarcação, e não fizeram comparação entre o CEB e um tecido compatível com a normalidade. Assim, fica a dúvida se há de fato um aumento de isoformas proteicas das MTs no CEB ou se na verdade há apenas um aumento da quantidade células que apresentam alguma marcação imunohistoquímica para MT1/2. Novos estudos são necessários para avaliar se há aumento ou redução da expressão proteica das MTs no CEB. Esta resposta não pode ser dada com base nos presentes resultados, pois mecanismos de regulação pós-transcricional podem estar atuantes neste processo (Miles et al., 2000; Vasconcelos et al., 2002; Arriaga et al., 2012). Além disso, devem ser desenvolvidas técnicas mais precisas para a detecção específica das isoformas ao nível proteico. Além disso, sugere-se que 
novo estudo seja realizado para avaliar se estes anticorpos realmente evidenciam as apo-MTs, pois as mesmas possuem conformação tridimensional distinta, não havendo informações na literatura se o epítopo E9 que é utilizado pelos anticorpos continua exposto. Postula-se que estudos que isolam a proteína apenas na forma holo-MT, a depender do tecido em análise, podem descartar até $90 \%$ da proteína (Yang et al., 2001).

A expressão do gene $M T 1 A$ não foi associada a nenhum dos parâmetros estudados para o CEB. Foi identificada queda significativa de sua expressão comparando o tumor (CEB) com o tecido benigno compatível (MOC), como também foi observado para adenocarcinomas colorretais (Arriaga et al., 2012), prostáticos (Garrett et al., 2000) e células malignas de tumores de mama (Tai et al., 2003). Garret e colaboradores (1998) observaram que o gene MT1A é minimamente expresso em células de túbulo proximal humano e é induzível por exposição metálica de maneira mais eficiente que MT1F e MT1X (Garrett et al., 1998). Outros achados relacionados ao $M T 1 A$ incluem a presença de mutações silenciosas em tumores de mama, mas nenhuma relação direta com o desenvolvimento tumoral foi estabelecida (Tai et al., 2003).

Os genes $M T 1 B, M T 1 H$ e MT1E não demonstraram alterações importantes comparando CEB com MOC. Com relação ao MT1B, não foi possível realizar qualquer análise, pois se observou ausência de sua expressão em praticamente todas as amostras. O gene $M T 1 H$ mostrou expressão em uma quantidade maior de casos. Porém, a expressão identificada para este gene foi extremamente baixa, não havendo possibilidade de identificar alguma amostra que pudesse ser utilizada na construção de uma curva padrão. Assim, as análises foram feitas comparando casos onde foi possível detectar alguma expressão de $M T 1 H$ com casos onde houve ausência completa de expressão. Nenhuma correlação foi estabelecida segundo os parâmetros do presente estudo neste sentido. Ausência de expressão de MT1B e MT1H tem sido relatada para vários tecidos (Mididoddi et al., 1996; Nguyen et al., 2000; Garrett et al., 2000; Sens et al., 2001; Jin et al., 2001; Tai et al., 2003) aparecendo aumentadas somente nos carcinomas de pulmão (Werynska et al., 2013b). Já para o gene MT1E os cálculos foram realizados pelo método da curva padrão, como para os outros genes. Sua expressão foi muito semelhante comparando CEB com a MOC. Na literatura observa-se importância da expressão deste gene apenas par tumores de mama, onde uma associação deste gene com 
marcação negativa para o receptor de estrógeno (RE) tem sido frequentemente demonstrada, sugerindo que possa ser um alvo para restabelecimento de RE ou um marcador de prognóstico associado para estes tumores (Jin et al., 2000; Tai et al., 2003; Sharkawy; Farrag, 2008).

O gene $M T 1 F$ foi o único que exibiu aumento significativo de expressão no CEB com relação à MOC. Um aumento de expressão deste gene apenas foi demonstrado anteriormente para casos de tumores malignos pulmonares em relação ao tecido normal, com aumento associado ao grau histológico e a casos de menor sobrevida (Werynska et al., 2013b). Diferentemente, em tumores de mama (Jin et al. 2002) e colorretais (Arriaga et al., 2012) foi observada uma queda de expressão de MT1F. Em tumores de mama a expressão de MT1F é mais evidente em células mioepiteliais normais e pode distinguir casos de tumores mamários com relação ao grau histológico (Jin et al., 2001; Jin et al., 2002). Assim, nota-se que o MT1F é regulado de maneira distinta nos cânceres de órgãos diferentes. No presente estudo esta expressão não se associou com nenhuma característica clínico-patológica ou relacionada ao prognóstico, exceto com relação ao tabagismo. Houve menor expressão em CEB de pacientes tabagistas $(p=0,02)$. Katsuragi e colaboradores (1997) observaram imunoexpressão significativamente aumentada de MT1/2 nos tecidos periodontais dos indivíduos tabagistas (Katsuragi et al., 1997). Também foi descrito este aumento em tumores e tecidos peri-tumorais de pulmão (Koomägi et al., 1996). Para carcinomas de mama, apenas relatou-se aumento de MT1/2 nos pacientes tabagistas do sexo feminino portadores de tumores bem diferenciados (Gallicchio et al., 2004). Desta forma, foram obtidos neste trabalho resultados para CEB que não vão de encontro com os já publicados, pois apontaram uma queda de expressão de $M T 1 F$ nos tabagistas. Porém, estes resultados não foram obtidos comparando a MOC dos pacientes (Apêndice A), o que pode indicar a presença de eventos biológicos intrínsecos ao CEB com relação ao tabagismo, ao invés de uma relação linear com o Cd presente no cigarro, por exemplo, que tem potencial de indução de MT1F (Sadhu; Gedamu, 1988). Além disso, nenhum outro estudo que avaliou a expressão gênica das MTs relatou associação com o tabagismo, sugerindo que este aumento pode ser dado por mecanismos pós-transcricionais. Por outro lado, como já mencionado, não se sabe se os anticorpos utilizados possuem real capacidade de identificação das apo-MTs. 
Os casos de CEB de baixa expressão do gene MT1G estiveram associados a menor sobrevida doença-específica $(p=0,042)$. Resultado semelhante foi obtido para tumores hepáticos, onde foi observada maior frequência de metilação da região promotora de MT1G em casos de menor sobrevida (Kanda et al., 2009). A metilação neste gene também foi observada em tumores de mama (Park et al., 2011), tireoide (Huang et al., 2003), próstata (Henrique et al., 2005), e colorretal (Arriaga et al., 2012). Em tumores de mama esta metilação é mais frequente em tumores de alto grau histológico, correlacionando-se ainda com a expressão de ki-67 (Park et al., 2011). Associação semelhante foi obtida quanto ao grau histológico de tumores prostáticos, identificando ainda casos de tumores que romperam a cápsula da próstata, ou seja, casos mais agressivos (Henrique et al., 2005). Em tireoide, o restabelecimento por transfecção de $M T 1 G$ em células $\mathrm{K} 1$ provoca crescimento e tumorigenicidade reduzidos (Ferrario et al., 2008). Neste sentido o MT1G foi colocado como um gene supressor de tumores em fígado e tireoide (Ferrario et al., 2008; Kanda et al., 2009). É possível que também ocorra metilação deste gene no CEB, mas um novo estudo precisa ser realizado para checar esta hipótese, e então o MT1G também poderia ser caracterizado como um supressor de tumor no CEB.

Uma alta expressão de MT1X não foi observada em casos de CEB metastáticos $(p=0,0294)$. Além disso, este gene apresentou-se frequentemente menos expresso no CEB do que na MOC ( $<<0,0001)$. Desta forma, o MT1X parece comportar-se como marcador de carcinogênese e progressão para o CEB. Uma ausência de expressão de $M T 1 X$ foi observada em tumores prostáticos enquanto que níveis basais predominam no tecido prostático normal (Garrett et al., 2000). No CEB, mesmo diante da queda de expressão dada pela transformação neoplásica, o MT1X mantém-se como um dos genes de maior expressão dentre os demais genes das MTs. De maneira semelhante, o MT1X juntamente com MT2A representam os genes de maior expressão dentre os outros, representando os únicos a correlacionarem-se com a expressão proteica MT1/2 (Arriaga et al., 2012). Porém os autores também comprovaram queda de expressão de MT1/2 por quantificação destas proteínas (Western blotting), o que nunca foi feito para CEB. Assim, tem sido descrito um aumento de proporção de células marcadas principalmente em citoplasma de CEB metastático (Szelachowska et al., 2009; Szelachowska et al., 2008). Neste sentido, os resultados não são compatíveis, lembrando-se da existência de mecanismos pós-transcricionais de regulação das MTs. 
O gene MT2A destaca-se na literatura porque parece ser o gene de maior expressão e potencial de indução dentre os genes das MTs (Richards et al. 1984; Sadhu; Gedamu, 1988). Esta grande participação do $M T 2 A$ na expressão proteica tem sido repetidamente demonstrada para tumores de mama, associando-se a um importante papel na carcinogênese e progressão tumoral (Davis; Cousins, 2000; Jin et al., 2002a; Jin et al., 2002; Yap et al., 2009). Sua expressão tem sido associada ao alto grau histológico (Jin et al., 2002), ao índice de proliferação dado por Ki-67 (Jin et al., 2002) e ao fenótipo invasivo (Kim et al., 2011) para tumores de mama. Seu silenciamento nestes tumores gera aumento de morte celular por entose (Lai et al., 2010) e inibição de fenótipo invasivo (Kim et al., 2011). Mais recentemente foi demonstrado que um SNP no gene MT2A (rs28366003) está associado ao maior risco de câncer de mama (Krześlak et al., 2012). Porém, no presente estudo apenas foi observada uma tendência de aumento de expressão comparando o CEB com a MOC. Além disso, não foi observada nenhuma associação com os outros parâmetros estudados. Apesar disto, não se pode descartar completamente sua importância para o CEB a partir deste estudo inicial, pois o mesmo possui limitações de análises, restringindo-se a dados clínico-patológicos e de seguimento.

Os genes MT3 e MT4 bem como seu produto proteico foram menos estudados na literatura com relação ao comportamento neoplásico. Sugere-se que esta carência deve-se ao fato de não haver anticorpos comerciais para MT3 e MT4 e porque representam isoformas que são minimamente induzíveis quando comparadas a MT1 e MT2 (Haq et al., 2003). Além disso, pensava-se que MT3 fosse restrita a tecidos neurais (Hoey et al., 1997) e MT4 a epitélios estratificados (Quaife et al., 1994). O gene MT3 foi um dos genes de menor expressão dentre os genes das MTs no CEB, havendo queda significativa de sua expressão no CEB em comparação com a MOC $(p=0,0005)$. Observou-se ainda, que os tumores metastáticos conservam maior expressão quando comparados com os não metastáticos $(p=0,0355)$. Casos de alta expressão de MT3 também foram mais frequentes em tumores de alto grau do pTNM $(p=0,049)$. Para carcinomas de esôfago foi demonstrado que o MT3 pode ser suprimido por metilação de sua região promotora. Os autores demonstraram que esta metilação associa-se a casos de tumores de estágio avançado e metástase linfonodal (Peng et al., 2011). Foi demonstrado que a queda de expressão de MT3 em casos de carcinoma gástrico (Deng et al., 2003) e de mama (Sens et al., 2001; Somji et al., 2010) também 
ocorrem por metilação, mas nenhuma associação com metástase foi investigada. Para tumores de pulmão a queda de expressão de MT3 esteve associada a casos de pior prognóstico (Werynska et al., 2013a). O mesmo foi observado, porém com relação ao aumento de MT3 para tumores de bexiga (Sens et al., 2000), mama (Sens et al., 2001) e próstata (Garrett et al., 1999). Estudos de expressão gênica das MTs ainda são iniciais e a descoberta dos mecanismos biológicos que circundam estas diferenças e fazem relação com a progressão de tumores diversos ainda está longe de ser esclarecida.

O gene MT4 também não apresentou alterações significativas com relação aos parâmetros clínico-patológicos e de prognóstico dos casos de CEB estudados. Porém, foi demonstrada queda significativa de sua expressão quando comparado com a MOC $(p=0,0052)$. São escassos os estudos que avaliaram o MT4. O trabalho mais clássico avaliou diversos órgãos de ratos, demonstrando por meio de hibridização in situ que sua expressão era restrita a epitélios estratificados como os de mucosa oral, esofágica, gástrica superior, epitélio da cauda, e pele neonatal. (Quaife et al., 1994). Utilizando PCR array com tumores de tireoide destacou-se a queda acentuada de expressão de MT4 em comparação com o tecido aparentemente normal, além de outros genes (Finn et al., 2007). Em tecido renal normal ou tumoral não se observou expressão de muitos dos genes das MTs, dentre eles o MT4 (Mididoddi et al., 1996; Nguyen et al., 2000). Estudos semelhantes identificaram queda de quase todos os genes das MTs nos tumores hepáticos, dentre eles o MT4 (lizuka et al., 2002; lizuka et al., 2005; Kanda et al., 2009). Para tumores pulmonares há aumento de expressão de quase todos os genes das MTs 1 e 2, mas a expressão de MT4 foi detectada em apenas 3,22\% dos casos (Werynska et al., 2013). A expressão reduzida de MT4 em CEB pode sugerir que o mesmo seja marcador de avanço da diferenciação celular epitelial, principalmente quando considerados os achados de Quaife e colaboradores (1994), que demonstraram sua expressão apenas nas camadas espinhosa e córnea dos epitélios estratificados. Favorece esta hipótese o fato de que a expressão de MT4 não foi detectada em $42,9 \%$ dos casos de CEB e $20 \%$ dos casos de MOC, ressaltando que na MOC não pode representar fielmente um tecido normal, pois está incluída na área de cancerização do CEB. Amostras de mucosa oral de pacientes sem histórico de CEB devem ser analisadas em novo estudo para colocar em cheque esta hipótese. 
O presente estudo mostra evidências de que as diferenças de regulação das MTs podem indicar predileção de comportamento metastático e pior prognóstico, principalmente com relação aos genes MT1G, MT1X e MT3 para o CEB. Outros trabalhos mostraram associação direta com piora de prognóstico com relação à expressão dos genes MT1F, MT2A e MT3 em tumores de pulmão (Werynska et al., 2013; Werynska et al., 2013), e MT3 para tumores de mama (Somji et al., 2010). Porém a maioria dos estudos que encontraram nas MTs este potencial estava avaliando a expressão proteica de $\mathrm{MT} 1 / 2$, como visto para o próprio CEB (Szelachowska et al., 2009), tumores de glândulas salivares (Brazão-Silva et al., 2013), de esôfago (Hishikawa et al., 1999), mucosa gástrica (Galizia et al., 2006), colorretal (Li el al., 2005) e glândulas mamárias (Haerslev et al., 1995; Schmid et al., 1993). Casos com maior frequência de células marcadas para MT1/2 também tiveram menor sobrevida em um estudo com amostras de CEB (Szelachowska et al., 2009). Frequentemente os estudos tem justificado esta maior agressividade com aumento de expressão de MTs pelo fato de que a mesma pode remover $\mathrm{Zn}$ da p53 anulando seu mecanismo anti-apoptótico e favorecendo a progressão tumoral (Butler; Loh, 2003; Rainwater, 1995; Cherian et al., 2003). Além disso, pode associar-se a maior expressão de p-Akt, além de ser capaz de remover o Zn das proteínas com dedos de Zn ligadas ao ADN, de Sp1 e do fator de transcrição IIIA (Zeng et al., 199; Zeng et al., 1991). De maneira surpreendente, observou-se neste estudo um predomínio de queda de expressão gênica das MTs no CEB, exceto para MT1F e MT2A. Vale aqui a mesma discussão de um parágrafo anterior, se realmente a imunohistoquímica identifica aumento de transcrição de proteínas ou aumento de conformações específicas das MTs, talvez identificando apenas MTs ligada a metais. Por outro lado, os genes MT1F e MT2A em conjunto poderiam ser responsáveis por um aumento real de expressão de MT1/2 quando comparado o CEB com o tecido normal, mas não se associaram a nenhuma característica relacionada ao prognóstico dos casos da presente amostra de CEB.

Não se sabe exatamente em quais processos irá interferir cada um dos genes das MTs, ou em resposta a qual processo eles estão sendo exatamente ativados. Sabe-se que os MREs estão presentes em todos os genes das MTs e podem ser distintamente ativados por átomos metálicos. Como visto em estudo clássico utilizando células HeLa, o Zn $\circ \mathrm{Cd}$ e $\circ \mathrm{Cu}$ excitam a transcrição gênica de maneira distinta, sendo que $M T 1 G$ e $M T 1 F$ respondem mais rapidamente ao $Z n$ do que ao 
Cd e $\mathrm{Cu}$, enquanto que $M T 2 A$ responde de maneira semelhante, mas sempre permanecendo com índices de expressão significativamente aumentados em relação aos outros genes (Sadhu; Gedamu, 1988). O MT1E tem resposta mais rápida ao $\mathrm{Cd}$ em relação aos outros genes em células KAT5, mas após 24 horas todos os outros genes de MT1 e MT2, exceto MT1B, superam de maneira significante a quantidade de transcritos do MT1E (Liu et al., 2009). Desta forma, observa-se que o papel das MTs com relação à homeostasia de metais tem regulação precisa de ativação gênica. Outro papel que é bem estabelecido das MTs se refere a seu potencial antioxidante e citoprotetor, principalmente por indução de expressão via AREs, mas também via MREs em algumas condições (Elgohary et al., 1998; Hidalgo et al., 2009; Kumari et al., 1998; Miura et al., 1997; Pitt et al., 1997). Neste sentido, também não seria errado sugerir que esta queda predominante de expressão gênica observada no CEB possa culminar na saturação das isoformas proteicas das MTs por metais tóxicos e/ou radicais livres, de maneira que em determinado momento não haja proteínas de MTs suficientes para conter os efeitos danosos destes elementos que então estimulam fenótipos tumorais mais agressivos. Como este é o primeiro trabalho de avaliação gênica das isoformas das MTs no CEB, fica difícil estabelecer comparações precisas, mas pode esta ser uma explicação para a maior frequência de casos de baixa expressão de $M T 1 G$ em pacientes que tiveram pior prognóstico e de MT1X em casos metastáticos. Além disso, há grande complexidade a ser desvendada sobre esta regulação gênica, que inclui outros componentes biológicos que podem participar na progressão tumoral como a presença de hormônios (glucagon, glicocorticoides), AMPc, interleucinas 1 e 6, intérferon, e fator de necrose tumoral (Davis; Cousins, 2000).

Em suma, o presente trabalho corrobora com as evidências de que as MTs podem ser marcadores biológicos tumorais. Destacou-se a queda de expressão da maioria dos genes quando comparado o CEB com a MOC, e, dentre estes genes, destacou-se o MT1G, MT1X e MT3. O primeiro pode ser marcador de prognóstico do CEB e os dois últimos marcadores de comportamento metastático tumoral. Ainda não existem maneiras precisas para explicar tais achados, mas, para o momento, confirma-se que os genes são regulados de maneira independente e abre-se mais um leque para pesquisas que o papel biológico das MTs seja esclarecido no CEB. 


\section{CONCLUSÕES}

1. Nem todos os genes das metalotioneínas estão expressos no carcinoma epidermoide bucal ou mesmo na mucosa oral não neoplásica dos pacientes, como foi o caso do MT1B em quase todas as amostras e o MT1H em mais de $80 \%$ dos casos.

2. Há diferenças significativas de regulação gênica das metalotioneínas no carcinoma epidermoide bucal quando comparado com a mucosa oral correspondente aos casos, com queda significativa de expressão para os genes MT1A, MT1X, MT3 e MT4 e aumento de expressão de MT1F.

3. A expressão gênica das metalotioneínas pode fornecer informações com relação ao prognóstico dos casos, como demonstrado pela maior frequência de casos de baixa expressão de $M T 1 G$ em pacientes com menor sobrevida.

4. A expressão gênica das metalotioneínas pode fornecer informações sobre o potencial metastático do carcinoma epidermoide bucal, como visto pela maior frequência de metástases para casos de baixa expressão para $M T 1 X$ e alta expressão de MT3. 


\section{REFERÊNCIAS ${ }^{2}$}

Abdel-mageed AB, Agrawal KC. Antisense down-regulation of metallothionein induces growth arrest and apoptosis in human breast carcinoma cells. Cancer Gene Ther. 1997;4(3):199-207.

Alves SM, Cardoso SV, de Fátima Bernardes V, Machado VC, Mesquita RA, Vieira do Carmo MA, et al. Metallothionein immunostaining in adenoid cystic carcinomas of the salivary glands. Oral Oncol. 2007;43(3):252-6.

Arriaga JM, Bravo IA, Bruno L, Morales Bayo S, Hannois A, Sanchez Loria F, et al. Combined metallothioneins and p53 proteins expression as a prognostic marker in patients with Dukes stage B and C colorectal cancer. Hum Pathol. 2012;43(10):1695-703.

Bier B, Douglas-Jones A, Totsch M, Dockhorn-Dworniczak B, Bocker W, Jasani B, et al. Immunohistochemical demonstration of metallothionein in normal human breast tissue and benign and malignant breast lesions. Breast Cancer Res Treat. 1994;30(3):213-21.

Bock JM, Sinclair LL, Bedford NS, Jackson RE, Lee JH, Trask DK. Modulation of cellular invasion by VEGF-C expression in squamous cell carcinoma of the head and neck. Arch Otolaryngol Head Neck Surg. 2008;134(4):355-62.

Bolha L, Dušanić D, Narat M, Oven I. Comparison of methods for relative quantification of gene expression using real-time PCR. Acta Agric Slov. 2012;100(2):97-106.

Brahimi-Horn M, Chiche J, Pouysségur J. Hipoxia and cancer. J Mol Med. 2007;85(12):1301-7.

Brandwein-Gensler M, Teixeira MS, Lewis CM, Lee B, Rolnitzky L, Hille JJ, et al. Oral squamous cell carcinoma: histologic risk assessment, but not margin status, is strongly predictive of local disease-free and overall survival. Am J Surg Pathol. 2005;29(2):167-78.

\footnotetext{
${ }^{2}$ De acordo com estilo Vancouver.
} 
Brazão-Silva MT, Cardoso SV, de Faria PR, Dias FL, Lima RA, Eisenberg ALA, et al. Adenoid cystic carcinoma of the salivary gland: a clinicopathological study of 49 cases and of metallothionein expression with regard to tumour behaviour. Histopathology. 2013;63(6):802-9.

Bremner I. Manifestations of copper excess. Am J Clin Nutr. 1998;67(5 Suppl):1069S-1073S.

Butler JS, Loh SN. Structure, function, and aggregation of the zinc-free form of the p53 DNA binding domain. Biochemistry. 2003;42(8):2396-403.

Cai B, Zheng Q, Teng X-C, Chen D, Wang Y, Wang K-Q, et al. The role of Thr5 in human neuron growth inhibitory factor. J Biol Inorg. Chem. 2006;11(4):476-82.

Cai L, Satoh M, Tohyama C, Cherian MG. Metallothionein in radiation exposure: its induction and protective role. Toxicology. 1999;132(2-3):85-98.

Cai L, Wang Y, Zhou G, Chen T, Song Y, Li X, et al. Attenuation by metallothionein of early cardiac cell death via suppression of mitochondrial oxidative stress results in a prevention of diabetic cardiomyopathy. J Am Coll Cardiol. 2006;48(8):1688-97.

Cardesa A, Gale N, Nadal A, Zidar N. Squamous cell carcinoma. In: Barnes L, Eveson J, Reichart P, Sidransky D, editors. World Health Organization Classifification of Tumours. Pathology and Genetics of Head and Neck Tumours. Lyon: IARC Press; 2005. p. 118-21.

Cardoso SV, Barbosa HM, Candellori IM, Loyola AM, Aguiar MCF. Prognostic impact of metallothionein on oral squamous cell carcinoma. Virchows Arch. 2002;441(2):174-8.

Cardoso SV, Silveira-Júnior J, de Carvalho Machado V, De-Paula A, Loyola AM, Aguiar MCF. Expression of metallothionein and p53 antigens are correlated in oral squamous cell carcinoma. Anticancer Res. 2009;29(4):1189-93.

Carvalho AL, Singh B, Spiro RH, Kowalski LP, Shah JP. Cancer of the oral cavity: a comparison between institutions in a developing and a developed nation. Head Neck. 2004;26(1):31-8.

Chan HM, Cherian MG. Ontogenic changes in hepatic metallothionein isoforms in prenatal and newborn rats. Biochem Cell Biol. 1993;71(3-4):133-40. 
Chari NS, Pinaire NL, Thorpe L, Medeiros LJ, Routbort MJ, McDonnell TJ. The p53 tumor suppressor network in cancer and the therapeutic modulation of cell death. Apoptosis. 2009;14(4):336-47.

Chauvin P, Cherian MG, Wysocki G, Pringle G. A comparison of metallothionein expression in human normal and neoplastic salivary gland tissue using immunohistochemistry. Toxicologist. 1992;12:379.

Chen L, Liu L, Huang S. Cadmium activates the mitogen-activated protein kinase (MAPK) pathway via induction of reactive oxygen species and inhibition of protein phosphatases 2A and 5. Free Radic Biol Med 2008;45(7):1035-44.

Chen P, Munoz A, Nettesheim D, Shaw CF, Petering DH. Stoichiometry and cluster specificity of copper binding to metallothionein: homogeneous metal clusters. Biochem J. 1996;317:395-402.

Cherian MG, Jayasurya A, Bay BH. Metallothioneins in human tumors and potential roles in carcinogenesis. Mutat Res. 2003;533:201-9.

Cherian MG, Kang Y. Metallothionein and liver cell regeneration. Exp Biol Med 2006;231(2):138-44.

Chimienti F, Seve M, Richard S, Mathieu J, Favier A. Role of cellular zinc in programmed cell death: temporal relationship between zinc depletion, activation of caspases, and cleavage of Sp family transcription factors. Biochem Pharmacol. $2001 ; 62(1): 51-62$.

Chin J, Banerjee D, Kadhin S, Kontozoglou T, Chauvin P, Cherian MG. Metallothionein in testicular germ cell tumors and drug resistance. Clinical correlation Cancer. 1993;72(10):3019-35.

Chu G. Cellular responses to cisplatin. The roles of DNA-binding proteins and DNA repair. J Biol Chem 1994;269(2):787-90.

Costello L, Franklin RB. Novel role of zinc in the regulation of prostrate citrate metabolism and its implications in prostrate cancer. Prostate 1998;35:285-96. 
Coyle P, Mathew G, Game PA, Myers JC, Philcox JC, Rofe AM, et al. Metallothionein in human oesophagus, Barrett's epithelium and adenocarcinoma. Br J Cancer. 2002a;87(5):533-6.

Coyle P, Philcox JC, Carey LC, Rofe AM. Cellular and Molecular Life Sciences Metallothionein: The multipurpose protein. Cel Mol Life Sci. 2002b;59(4):627-47.

Datta J, Majumder S, Kutay H, Motiwala T, Frankel W, Costa R, et al. Metallothionein Expression Is Suppressed in Primary Human Hepatocellular Carcinomas and Is Mediated through Inactivation of CCAAT / Enhancer Binding Protein A by Phosphatidylinositol 3-Kinase Signaling Cascade. Cancer Res. 2007;(6):2736-46.

Davis SR, Cousins RJ. Recent Advances in Nutritional Sciences Metallothionein Expression in Animals : A Physiological Perspective on Function 1. Experientia. 2000;1(21):1085-8.

Deng D, El-rifai W, Ji J, Zhu B, Trampont P, Li J, et al. Hypermethylation of metallothionein-3 CpG island in gastric carcinoma. Carcinogenesis. 2003;24(1):25-9.

Deng DX, Chakrabarti S, Waalkes MP, Cherian MG. Metallothionein and apoptosis in primary human hepatocellular carcinoma and metastatic adenocarcinoma. Histopathology. 1998;32(4):340-7.

Dufner-beattie J, Langmade SJ, Wang F, Eide D, Andrews GK, Biol DJJ. Structure, Function, and Regulation of a Subfamily of Mouse Zinc Transporter Genes. Biochemistry. 2003;278(50):50142-50.

Duncan KER, Ngu TT, Chan J, Salgado MT, Merrifield ME, Stillman MJ. Peptide folding, metal-binding mechanisms, and binding site structures in metallothioneins. Exp Biol Med (Maywood). 2006;231(9):1488-99.

Dutsch-Wicherek M, Sikora J, Tomaszewska R. The possible biological role of metallothionein in apoptosis. Front Biosci. 2008;1(13):4029-38.

Dutta R, Sens DA, Somji S, Sens MA, Garrett SH. Metallothionein isoform 3 expression inhibits cell growth and increases drug resistance of PC-3 prostate cancer cells. Prostate. 2002;52(2):89-97. 
Ebert M, Gunther T, Hoffmann J, Yu J, Miehlke S, Schulz HU, et al. Expression of metallothionein II in intestinal metaplasia, dysplasia, and gastric cancer. Cancer Res. 2000;60(7):1995.

Eid H, Geczi L, Bodrogi I, Institoris E, Bak M. Do metallothioneins affect the response to treatment in testis cancers? J Cancer Res Clin Oncol. 1998;124:31-6.

Elgohary WG, Sidhu S, Krezoski SO, Petering DH, Byrnes RW. Protection of DNA in $\mathrm{HL}-60$ cells from damage generated by hydroxyl radicals produced by reaction of H2O2 with cell iron by zinc-metallothionein. Chem Biol Interact 1998;115(2):85-107.

El-Rifai W, Frierson HF, Harper JC, Powell SM, Knuutila S. Expression profiling of gastric adenocarcinoma using cDNA array. Int J Cancer. 2001;92(6):832-8.

Endo T, Yoshikawa M, Ebara M, Kato K, Sunaga M, Fukuda H, et al. Immunohistochemical metallothionein expression in hepatocellular carcinoma: relation to tumor progression and chemoresistance to platinum agents. J Gastroenterol. 2004;39(12):1196-201.

Erickson JC, Hollopeter G, Thomas SA, Froelick GJ, Palmiter RD. Disruption of the metallothionein-III gene in mice: analysis of brain zinc, behavior, and neuron vulnerability to metals, aging, and seizures. J Neurosci. 1997;17(4):1271-81.

Fang J, Nakamura $\mathrm{H}$, lyer AK. Tumor-targeted induction of oxystress for cancer therapy. J. Drug Target. 2007;15(7-8):475-86.

Farias TP De, Dias FL, Duque G, Rangel L. Análise crítica da aplicação da pesquisa do linfonodo sentinela no tratamento do câncer inicial de boca. Rev Bras Cir cabeça e pescoço. 2009;38(2):98-102.

Feldman SL, Failla ML, Cousins RJ. Degradation of rat liver metallothioneins in vitro. Biochim Biophys Acta. 1978;544(3):638-46.

Feller L, Wood NH, Khammissa RAG, Lemmer J. Human papillomavirus-mediated carcinogenesis and HPV-associated oral and oropharyngeal squamous cell carcinoma. Part 2: Human papillomavirus associated oral and oropharyngeal squamous cell carcinoma. Head Face Med. 2010;6:15.

Feng P, Liang J, Li T, Guang Z, Zou J, R F. Zinc induces mitochondria apoptogenesis in prostate cells. Mol Urol. 2000;4:31-6. 
Ferlay J, Soerjomataram I, Ervik M, Dikshit R, Eser S, Mathers C, Rebelo M, Parkin DM, Forman D, Bray, F. GLOBOCAN 2012 v1.0, Cancer Incidence and Mortality Worldwide: IARC CancerBase No. 11 [Internet]. Lyon, France: International Agency for Research on Cancer; 2013. Available from: http://globocan.iarc.fr

Ferrario C, Lavagni P, Gariboldi M, Miranda C, Losa M, Cleris L, et al. Metallothionein $1 \mathrm{G}$ acts as an oncosupressor in papillary thyroid carcinoma. Lab. Invest. 2008;88(5):474-81.

Finn S, Smyth P, Cahill S, Streck C, O’Regan E, Fravin R, et al. Expression microarray analysis of papillary thyroid carcinoma and benign thyroid tissue: emphasis on the follicular variant and potential markers of malignancy. Virchows Arch. 2007;450(3):249-60.

Fischer EH, Davie EW. Commentary Recent excitement regarding metallothionein. Proc Natl Acad Sci. USA. 1998;95(7):3333-4.

Frassinetti S, Bronzetti G, Caltavuturo L, Cini M, Croce C Della. The role of zinc in life: a review. J Environ Pathol Toxicol Oncol. 2006;25(3):597-610.

Fresno M, Wu W, Rodriguez J, Nadji M. Localization of metallothionein in breast carcinomas. An immunohistochemical study. Virchows Arch A Pathol Anat Histopathol. 1993;423(3):215-9.

Galizia G, Ferraraccio F, Lieto EVA, Orditura M. p27 Downregulation and Metallothionein Overexpression in Gastric Cancer Patients Are Associated With a Poor Survival Rate. J Surg Oncol. 2006;93(3):241-52.

Gallicchio L, Flaws J a, Sexton M, loffe OB. Cigarette smoking and metallothionein expression in invasive breast carcinomas. Toxicol. Lett. 2004;152(3):245-53.

Gallicchio LM, Flaws JA, Fowler B, loffe OB. Metallothionein expression in invasive and in situ breast carcinomas. Cancer Detect Prev. 2005;29(4):332-7.

Gao Y, Han Z, Liu X. Metallothionein expression and its significance in salivary gland tumors. Zhonghua Kou Qiang Yi Xue Za Zh. 1997;32(5):282-4. 
Garrett SH, Sens MA, Shukla D, Flores L, Somji S, Todd JH, et al. Metallothionein isoform 1 and 2 gene expression in human prostate: downregulation of MT-1X in advanced prostate cancer. Prostate. 2000;43:125-35.

Garrett SH, Sens MA, Shukla D, Nestor S, Somji S, Todd JH, et al. Metallothionein isoform 3 expression in the human prostate and cancer-derived cell lines. Prostate. 1999;41(3):196-202.

Garrett SH, Somji S, Todd JH, Sens MA, Sens DA. Differential expression of human metallothionein isoform I mRNA in human proximal tubule cells exposed to metals. Environ. Health Perspect. 1998;106(12):825-31.

Giuffrè G, Barresi G, Sturniolo G, Sarnelli R, D'Incà R, Tucarri G. Immunohistochemical expression of metallothionein in normal human colorectal mucosa, in adenomas and in adenocarcinomas and their associated metastases. Histopathology. 1996;29(4):347-54.

Guinot JL, Santos M, Tortajada MI, Carrascosa M, Estellés E, Vendrell JB, et al. Efficacy of high-dose-rate interstitial brachytherapy in patients with oral tongue carcinoma. Brachytherapy. 2010;9(3):227-34 .

Haerslev T, Jacobsen G, Zedeler K. The prognostic significance of immunohistochemically detectable metallothionein in primary breast carcinomas. APMIS. 1995;103(4):279-85.

Hamer DH. Metallothionein1,2. Ann Rev Biochem. 1986;55:913-51.

Haq F, Mahoney M, Koropatnick J. Signaling events for metallothionein induction. Mutat Res. 2003;533(1-2):211-26.

Harada H, Omura K, Nakajima Y, Hasegawa S, Mogi S. Cyclin B1 is useful to predict occult cervical lymph node metastases in tongue carcinoma. J Exp Clin Cancer Res. 2006;25(3):351-6.

Henrique R, Jerónimo C, Hoque MO, Nomoto S, Carvalho AL, Costa VL, et al. MT1G hypermethylation is associated with higher tumor stage in prostate cancer. Cancer Epidemiol Biomarkers Prev. 2005;14(5):1274-8.

Hidalgo J, Chung R, Penkowa M, Vasak M. Structure and function of vertebrate Metallothioneins. Met lons Life Sci. 2009;5:279-317. 
Hishikawa Y, Abe S, Kinugasa S, Yoshimura H, Monden N, Igarashi M, et al. Overexpression of metallothionein correlates with chemoresistance to cisplatin and prognosis in esophageal cancer. Oncology. 1997;54(4):342-7.

Hishikawa Y, Koji T, Dhar DK, Kinugasa S, Yamaguchi M, Nagasue N.

Metallothionein expression correlates with metastatic and proliferative potential in squamous cell carcinoma of the oesophagus. Br J Cancer. 1999;81(4):712-20.

Hoey JG, Garrent SH, Sens MA, Todd JH, Sens DA. Expression of MT-3 mRNA in human kidney, proximal tubule cell cultures, and renal cell carcinoma. Toxicol Lett. 1997;92:149-60.

Hozumi I, Inuzuka T, Ishiguro H, Hiraiwa M, Uchida Y, Tsuji S. Immunoreactivity of growth inhibitory factor in normal rat brain and after stab wounds--an immunocytochemical study using confocal laser scan microscope. Brain Res. 1996;741(1-2):197-204.

Huang M, CF SI, Petering DH. Interprotein metal exchange between transcription factor IIla and apo-metallothionein. J Inorg Biochem. 2004;98(4):639-48.

Huang S-F, Cheng S-D, Chuang W-Y, Chen I-H, Liao C-T, Wang H-M, et al. Cyclin D1 overexpression and poor clinical outcomes in Taiwanese oral cavity squamous cell carcinoma. World J Surg Oncol. 2012;10:40.

Huang Y, de la Chapelle A, Pellegata NS. Hypermethylation, but not $L O H$, is associated with the low expression of MT1G and CRABP1 in papillary thyroid carcinoma. Int. J. Cancer [Internet]. 2003;104(6):735-44.

Huber GF, Fritzsche FR, Züllig L, Storz M, Graf N, Haerle SK, et al. Podoplanin expression correlates with sentinel lymph node metastasis in early squamous cell carcinomas of the oral cavity and oropharynx. Int. J. Cancer. 2011;129(6):1404-9.

lizuka N, Oka M, Yamada-Okabe H, Mori N, Tamesa T, Okada T, et al. Comparison of gene expression profiles between hepatitis $B$ virus- and hepatitis $C$ virus-infected hepatocellular carcinoma by oligonucleotide microarray data on the basis of a supervised learning method. Cancer Res. 2002;62(14):3939-44.

lizuka N, Oka M, Yamada-Okabe H, Mori N, Tamesa T, Okada T, et al. Selforganizing-map-based molecular signature representing the development of hepatocellular carcinoma. FEBS Lett. 2005;579(5):1089-100.

Instituto Nacional de Câncer José Alencar Gomes da Silva. Estimativa 2014: incidência de câncer no Brasil. Rio de Janeiro: INCA; 2014. 
loachim E, Kamina S, Demou A, Kontostolis M, Lolis D, Agnantis N.

Immunohistochemical localization of metallothionein in human breast cancer in comparison with cathepsin D, stromelysin-1, CD44, extracellular matrix components, P53, Rb, C-erbB-2, EGFR, steroid receptor content and proliferation. Anticancer Res. $1999 ; 19(3 \mathrm{~A}): 2133-9$.

Irie Y, Mori F, Keung W, Mizushima Y, Wakabayashi K. Expression of neuronal growth inhibitory factor (metallothionein-III) in the salivary gland. Physiol Res. 2004;53(6):719-23.

Jackson MS, Wrench AA, Soutar DS, Robertson AG. Carcinoma of the tongue: the speech therapist's perspective. Br J Oral Maxillofac Surg. 1999;37(3):200-4.

Janssen AML, Duijn W Van, Kubben FJGM, Griffioen G, Krieken JHJM Van, Velde CJH Van De. Prognostic Significance of Metallothionein in Human Gastrointestinal Cancer 1. Clin Cancer Res. 2002;8:1889-1896.

Janssen AML, Duijn W Van, Ruit MMO De, Kruidenier L, Bosman CB, Grif G, et al. Metallothionein in human gastrointestinal cancer. J Pathol. 2000;9896:293-300.

Jayasurya A, Bay B-H, Yap W, Tan N. Correlation of metallothionein expression with apoptosis in nasopharyngeal carcinoma. Br J Cancer. 2000;82(6):1198-203.

Jiang L, Maret W, Vallee BL. The glutathione redox couple modulates zinc transfer from metallothionein to zinc-depleted sorbitol dehydrogenase. Proc Natl Acad Sci USA. 1998;95(7):3483-8.

Jihen $\mathrm{EH}$, Imed M, Fatima H, Abdelhamid K. Protective effects of selenium (Se) and zinc $(\mathrm{Zn})$ on cadmium $(\mathrm{Cd})$ toxicity in the liver of the rat: effects on the oxidative stress. Ecotoxicol. Environ Saf. 2009;72(5):1559-64.

Jin R, Bay B, Chow V, Tan P. Metallothionein 1F mRNA expression correlated with histological grade in breast carcinoma. Breast Cancer Res. Treat. 2002;23(1):81-6.

Jin R, Bay B, Chow V, Tan P, Dheen T. Significance of metallothionein expression in breast myoepithelial cells. Cell Tissue Res. 2001;303:221-6.

Jin R, Bay BH, Chow VTK, Tan PH, Lin VCL. Metallothionein 1E mRNA is highly expressed in oestrogen receptor-negative human invasive ductal breast cancer. Imaging. 2000;83:319-23. 
Jin R, Chow VT, Tan P, Dheen ST, Duan W, Bay B. Metallothionein 2A expression is associated with cell proliferation in breast cancer. Carcinogenesis. 2002b;23(1):81-6.

Johann ACBR, da Silveira-Júnior JB, Souto GR, Horta MC, Aguiar MCF, Mesquita RA. Metallothionein immunoexpression in oral leukoplakia. Med. Oral Patol. Oral Cir. Bucal. 2008;13(3):E156-60.

Johnson N, Franceschi S, Ferlay J, Ramadas K, Schmid S, MacDonald D, et al. Squamous cell carcinoma. In: Barnes L, Eveson J, Reichart P, Sidransky D, editors. World Health Organization Classification of Tumours. Pathology and Genetics of Head Neck Tumours. Lyon: IARC Press; 2005. p. 168-75.

Juang $\mathrm{H}-\mathrm{H}$, Chung L-C, Sung H-C, Feng T-H, Lee Y-H, Chang P-L, et al. Metallothionein 3: an androgen-upregulated gene enhances cell invasion and tumorigenesis of prostate carcinoma cells. Prostate. 2013;73(14):1495-506.

Kägi JH, Kojima Y. Chemistry and biochemistry of metallothionein. Experientia Suppl. 1987;52:25-61.

Kanda M, Nomoto S, Okamura Y, Nishikawa Y, Sugimoto H, Kanazumi N, et al. Detection of metallothionein $1 G$ as a methylated tumor suppressor gene in human hepatocellular carcinoma using a novel method of double combination array analysis. Int J Oncol. 2009;35(3):477-83.

Katsuragi $\mathrm{H}$, Hasegawa A, Saito K. Distribution of metallothionein in cigarette smokers and non-smokers in advanced periodontitis patients. J Periodontol. 1997;68(10):1005-9.

Kay J, Cryer A, Darke BM, Kille P, Lees WE, Norey CG, et al. Naturally occurring and recombinant metallothioneins: structure, immunoreactivity and metal-binding functions. Int J Biochem. 1991;23(1):1-5.

Kille P, Kay J, Sweeney GE. Analysis of regulatory elements flanking metallothionein genes in Cd-tolerant fish (pike and stone loach). Biochim Biophys Acta. 1993;1216(1):55-64.

Kim CH, Kim JH, Lee J, Ahn YS. Zinc-induced NF-kappaB inhibition can be modulated by changes in the intracellular metallothionein level. Toxicol Appl Pharmacol. 2003;190(2):189-96. 
Kim HG, Kim JY, Han EH, Hwang YP, Choi JH, Park BH, et al. Metallothionein-2A overexpression increases the expression of matrix metalloproteinase- 9 and invasion of breast cancer cells. FEBS Lett. 2011;585(2):421-8.

Klaassen C, Choudhuri S, McKim Jr J, Lehman-McKeeman L, Kershaw W. In vitro and in vivo studies on the degradation of metallothionein. Environ Health Perspect. 1994;102(Suppl 3):141-6.

Klaassen CD, Liu J, Choudhuri S. Metallothionein: an intracellular protein to protect against cadmium toxicity. Annu Rev Pharmacol Toxicol. 1999;39:267-94.

Kolker JL, Ismail AI, Sohn W, Ramaswami N. Trends in the incidence, mortality, and survival rates of oral and pharyngeal cancer in a high-risk area in Michigan, USA. Community Dent. Oral Epidemiol. 2007;35(6):489-99.

Kondo Y, Rusnak JM, Hoyt DG, Settineri CE, Pitt BR, Lazo JS. Enhanced apoptosis in metallothionein null cells. Mol Pharmacol. 1997;52:195-201.

Kontozoglou T, Banerjee D, Cherian MG. Immuno-histochemical localization of metallothionein in human testicular embryonal carcinoma cells. Virchows Arch A Pathol Anat Histopathol. 1989;415(6):545-9.

Koomägi R, Stammler G, Manegold C, Mattern J, Volm M. Expression of resistancerelated proteins in tumoral and peritumoral tissues of patients with lung cancer. Cancer Lett. 1996;110(1-2):129-36.

Kotoh S, Naito S, Sakamoto N, Goto K, Kumazawa J. Metallothionein expression is correlated with cisplatin resistance in transitional cell carcinoma of the urinary tract. J Urol. 1994;152(4):1267-70.

Kraker AJ, Krakower G, lii CFS, Protein Z, Petering DH, Garvey JS. Zinc Metabolism in Ehrlich Cells : Properties of a Metallothionein-like Zinc-binding Protein. Cancer Res. 1988;48:3381-8.

Kreimer AR, Clifford GM, Boyle P, Franceschi S. Human papillomavirus types in head and neck squamous cell carcinomas worldwide: a systematic review. Cancer Epidemiol Biomarkers Prev. 2005;14(2):467-75. 
Królicka A, Kobierzycki C, Puła B, Podhorska-Okołów M, Piotrowska A, Rzeszutko M, et al. Comparison of metallothionein (MT) and Ki-67 antigen expression in benign and malignant thyroid tumours. Anticancer Res. 2010(12):4945-9.

Krześlak A, Forma E, Jóźwiak P, Szymczyk A, Smolarz B, Romanowicz-Makowska $\mathrm{H}$, et al. Metallothionein 2A genetic polymorphisms and risk of ductal breast cancer. Clin Exp Med. 2012.

Kumari MV, Hiramatsu M, Ebadi M. Free radical scavenging actions of metallothionein isoforms I and II. Free Radic. Res. 1998;29(2):93-101.

Lai Y, Lim D, Tan P-H, Leung TK-C, Yip GW-C, Bay B-H. Silencing the Metallothionein-2A gene induces entosis in adherent MCF-7 breast cancer cells. Anat Rec (Hoboken). 2010;293(10):1685-91.

Lee DK, Carrasco J, Hidalgo J, Andrews GK. Identification of a signal transducer and activator of transcription (STAT) binding site in the mouse metallothionein-I promoter involved in interleukin- 6-induced gene expression. Stat. 1999;337:59-65.

Lee S, Yang S, Ho Y, Tsai C, Chang Y. The upregulation of metallothionein-1 expression in areca quid chewing-associated oral squamous cell carcinomas. Oral Oncol. 2008;44(2):180-6.

Leite IC, Koifman S. Survival analysis in a sample of oral cancer patients at a reference hospital in Rio de Janeiro, Brazil. Oral Oncol. 1998;34(5):347-52.

León X, Hitt R, Constenla M, Rocca A, Stupp R, Kovács AF, et al. A retrospective analysis of the outcome of patients with recurrent and/or metastatic squamous cell carcinoma of the head and neck refractory to a platinum-based chemotherapy. Clin Oncol (R. Coll. Radiol). 2005;17(6):418-24.

Li S, Yu B, An P, Zuo F, Cai H. Expression of metallothionein and FasL in colorectal cancer and its clinical significance. Zhonghua Wai Ke Za Zhi. 2005;43(12):1118-20.

Li Y, Wo JM, Cai L, Zhou Z, Rosenbaum D, Mendez C, et al. Association of metallothionein expression and lack of apoptosis with progression of carcinogenesis in Barrett's esophagus. Exp Biol Med (Maywood). 2003;228(3):286-92. 
Lim YC, Han JH, Kang HJ, Kim YS, Lee BH, Choi EC, et al. Overexpression of c-Met promotes invasion and metastasis of small oral tongue carcinoma. Oral Oncol. 2012;48(11):1114-9.

Liu J, Qian SY, Guo Q, Jiang J, Waalkes MP, Mason RP, et al. Cadmium generates reactive oxygen- and carbon-centered radical species in rats: insights from in vivo spin-trapping studies. Free Radic. Biol. Med. 2008;45(4):475-81.

Liu M, Lawson G, Delos M, Jamart J, Ide C, Coche E, et al. Predictive value of the fraction of cancer cells immunolabeled for proliferating cell nuclear antigen or Ki67 in biopsies of head and neck carcinomas to identify lymph node metastasis:

comparison with clinical and radiologic examinations. Head Neck. 2003;25(4):280-8.

Liu Z, Hasselt CA Van, Song F, Vlantis AC, Cherian MG, Koropatnick J, et al. Molecular and Cellular Endocrinology Expression of functional metallothionein isoforms in papillary thyroid cancer. Mol. Cell. Endocrinol. 2009;302:92-8.

Lo W-L, Kao S-Y, Chi L-Y, Wong Y-K, Chang RC-S. Outcomes of oral squamous cell carcinoma in Taiwan after surgical therapy: factors affecting survival. J Oral Maxillofac Surg. 2003;61(7):751-8.

Maret W, Jacob C, Vallee BL, Fischer E. Inhibitory sites in enzymes: zinc removal and reactivation by thionein. Proc Natl Acad Sci USA. 1999;96(5):1936-40.

Margoshes M, Vallee B. A cadmium protein from equine kidney cortex. J Am Chem Soc. 1957;79:4813.

Marr MT, Isogai Y, Wright KJ, Tjian R. Coactivator cross-talk specifies transcriptional output. Genes Dev. 2006;20(11):1458-69.

Massano J, Regateiro FS, Januário G, Ferreira A. Oral squamous cell carcinoma: review of prognostic and predictive factors. Oral Surg Oral Med Oral Pathol Oral Radiol Endod. 2006;102(1):67-76.

Masters BA, Quaife CJ, Erickson JC, Kelly EJ, Froelick GJ, Zambrowicz BP, et al. Metallothionein III is expressed in neurons that sequester zinc in synaptic vesicles. J. Neurosci. 1994;14(10):5844-57. 
Matos FR, Lima E das N de A, Queiroz LMG, da Silveira EJD. Analysis of inflammatory infiltrate, perineural invasion, and risk score can indicate concurrent metastasis in squamous cell carcinoma of the tongue. J Oral Maxillofac Surg 2012;70(7):1703-10.

Mees C, Nemunaitis J, Senzer N. Transcription factors: their potential as targets for an individualized therapeutic approach to cancer. Cancer Gene Ther. 2009;16(2):103-12.

Meijer C, Timmer A. Role of metallothionein in cisplatin sensitivity of germ-cell tumours. J Cancer. 2000;781:777-81.

Mididoddi S, Mcguirt JP, Sens MA, Todd JH, Sens DA. Toxicology Letters Isoformspecific expression of metallothionein mRNA in the developing and adult human kidney. Toxicol Lett. 1996;85:17-27.

Miles AT, Hawksworth GM, Beattie JH, Rodilla V. Induction, Regulation , Degradation and Biological Significance of Mammalian Metallothioneins. Crit Rev Biochem. 2000;35(1):35-70.

Mitani T, Shirasaka D, Aoyama N, Miki I, Morita Y. Role of metallothionein in Helicobacter pylori-positive gastric mucosa with or without early gastric cancer and the effect on its expression after eradication therapy. J Gastroenterol Hepatol. 2008;23(8 Pt 2):334-9.

Miura T, Muraoka S, Ogiso T. Antioxidant activity of metallothionein compared with reduced glutathione. Life Sci. 1997;60(21):301-9.

Miyahara M, Tanuma J-I, Sugihara K, Semba I. Tumor lymphangiogenesis correlates with lymph node metastasis and clinicopathologic parameters in oral squamous cell carcinoma. Cancer. 2007;110(6):1287-94.

Miyashita $\mathrm{H}$, Sato $\mathrm{Y}$. Metallothionein 1 is a downstream target of vascular endothelial zinc finger 1 (VEZF1) in endothelial cells and participates in the regulation of angiogenesis. Endothelium. 2005;12(4):163-70.

Moleirinho A, Carneiro J, Matthiesen R, Silva RM, Amorim A, Azevedo L. Gains, losses and changes of function after gene duplication: study of the metallothionein family. PLoS One. 2011;6(4):18487. 
Monden N, Abe S, Sutoh I, Hishikawa Y, Kinugasa S, Nagasue N. Prognostic significance of the expression of metallothionein, Glutation-S-transferase, and Pglicoprotein in curatively resected gastric cancer. Oncology. 1997;54(5):391-9.

Moussa M, Kloth D, Peers G, Cherian MG, Frei J, Chin J. Metallothionein expression in prostatic carcinoma: correlation with Gleason grade, pathologic stage, DNA content and serum level of prostate-specific antigen. Clin Invest Med. 1997;20(6):371-80.

Muramatsu Y, Hasegawa Y, Fukano H, Ogawa T, Namuba M, Mouri K, et al. Metallothionein immunoreactivity in head and neck carcinomas; special reference to clinical behaviors and chemotherapy responses. Anticancer Res. 2000;20(1A):25764.

Myoung H, Kim M-J, Lee J-H, Ok Y-J, Paeng J-Y, Yun P-Y. Correlation of proliferative markers (Ki-67 and PCNA) with survival and lymph node metastasis in oral squamous cell carcinoma: a clinical and histopathological analysis of 113 patients. Int. J. Oral Maxillofac. Surg. 2006;35(11):1005-10.

Nakano M, Sogawa CA, Sogawa N, Mishima K, Yamachika E, Mizukawa N, et al. Expression pattern of cisplatin-induced metallothionein isoforms in squamous cell carcinoma. Anticancer Res. 2003;23(1A):299-303

Nartey N, Cherian MG, Banerjee D. Immunohistochemical localization of metallothionein in human thyroid tumors. Am J Pathol. 1987;129(1):177-82.

Neville BW, Damm DD, Allen CM, Bouquot JE. Patologia oral e maxilofacial. 2nd ed. Rio de Janeiro: Guanabara Koogan; 2004. p. 373-413.

Ngu TT, Easton A, Stillman MJ. Kinetic analysis of arsenic-metalation of human metallothionein: significance of the two-domain structure. J Am Chem Soc. 2008;130(50):17016-28.

Nguyen A, Jing Z, Mahoney PS, Davis R, Sikka SC, Agrawal KC, et al. In vivo gene expression prole analysis of metallothionein in renal cell carcinoma. Cancer Lett. 2000;160:133-40.

Nielsen AE, Bohr A, Penkowa M. The Balance between Life and Death of Cells: Roles of Metallothioneins. Biomark Insights. 2007;1:99-111. 
Nordberg GF, Nordberg M, Piscator M, Vesterberg O. Separation of two forms of rabbit metallothionein by isoelectric focusing. Biochem J. 1972 Feb;126(3):491-8.

Nordberg M. Metallothioneins: historical review and state of knowledge. Talanta. 1998;46(2):243-54.

Nordberg M, Nordherg GF. Metallothioneins: Historical Development and Overview. In: Siegel A, Siegel H, Sigel RKO, editors. Metallothioneins and related chelators. London: Springer; 2009. (Metal ions in life science; vo. 5).

O-charoenrat P, Pillai G, Patel S, Fisher C, Archer D, Eccles S, et al. Tumour thickness predicts cervical nodal metastases and survival in early oral tongue cancer. Oral Oncol. 2003;39(4):386-90.

Ofner D, Maier H, Riedmann B, Bammer T, Rumer A, Winde G, et al. Immunohistochemical metallothionein expression in colorectal adenocarcinoma: correlation with tumour stage and patient survival. Virchows Arch. 1994;425(5):4917.

Oliveira LR, Ribeiro-Silva A, Zucoloto S. Prognostic impact of p53 and p63 immunoexpression in oral squamous cell carcinoma. J Oral Pathol Med. 2007;36(4):191-7.

Oliveira LR, Ribeiro-Silva. Prognostic significance of immunohistochemical biomarkers in oral squamous cell carcinoma. Int J Oral Maxillofac Surg. 2011;40(3):298-307.

Oyama T, Take H, Hikino T, Lino Y, Nakajima T. Immunohistochemical expression of metallothionein in invasive breast cancer in relation to proliferative activity, histology and prognosis. Oncology. 1996;53(2):112-7.

Palmiter RD. Regulation of metallothionein genes by heavy metals appears to be mediated by a. Proc Natl Acad Sci USA. 1994;91(2):1219-23.

Pan Y, Huang J, Xing R, Yin X, Cui J, Li W, et al. Metallothionein 2A inhibits NF-kB pathway activation and predicts clinical outcome segregated with TNM stage in gastric cancer patients following radical resection. J Transl Med. 2013;11:173. 
Park SY, Kwon HJ, Lee HE, Ryu HS, Kim S-W, Kim JH, et al. Promoter CpG island hypermethylation during breast cancer progression. Virchows Arch. 2011;458(1):7384.

Pascalicchio AE. Contaminação por metais pesados: saúde pública e medicina ortomolecular. São Paulo: Annablume; 2002. p. 132.

Pastuszewski W, Dziegiel P, Krecicki T, Podhorska-Okolow M, Ciesielska U, Gorzynska E, et al. Prognostic significance of metallothionein, p53 protein and Ki-67 antigen expression in laryngeal cancer. Anticancer Res. 2007;27(1A):335-42.

Pedersen M, Larsen A. The role of metallothionein in oncogenesis and cancer prognosis. Histochem. 2009;44:29-64.

Peng D, Hu T-L, Jiang A, Washington MK, Moskaluk CA, Schneider-Stock R, et al. Location-specific epigenetic regulation of the metallothionein 3 gene in esophageal adenocarcinomas. PLoS One. 2011;6(7):22009.

Penkowa M. Metallothioneins are multipurpose neuroprotectants during brain pathology. FEBS J. 2006;273(9):1857-70.

Penkowa M, Carrasco J, Giralt M, Molinero A, Hernandez J, Campbell I, et al. Altered central nervous system cytokine-growth factor expression profiles and angiogenesis in metallothionein-I+II deficient mice. J Cereb Blood Flow Metab. 2000;20(8):117489.

Perry D, Smyth M, Stennick H, Salvesen G, Duriez P, Poirier G, et al. Zinc is a potent inhibitor of the apoptotic protease, caspase-3. A novel target for zinc in the inhibition of apoptosis. J Biol Chem. 1997;272(30):18530-3.

Petering DH, Zhu J, Krezoski S, Meeusen J, Kiekenbush C, Krull S, et al. ApoMetallothionein Emerging as a Major Player in the Cellular Activities of Metallothionein. Exp Biol Med. 2006;231(9):1528-34.

Peterson MG, Hannan F, Mercer JF. The sheep metallothionein gene family. Structure, sequence and evolutionary relationship of five linked genes. Eur. J. Biochem. 1988;174(2):417-24.

Pfaffl MW. A new mathematical model for relative quantification in real-time RT-PCR. Nucleic Acids Res. 2001;29(9):45. 
Piccirillo JF, Lacy PD, Basu A, Spitznagel EL. Development of a new head and neck cancer-specific comorbidity index. Arch Otolaryngol Head Neck Surg. 2002;128(10):1172-9.

Pitt BR, Schwarz M, Woo ES, Yee E, Wasserloos K, Tran S, et al. Overexpression of metallothionein decreases sensitivity of pulmonary endothelial cells to oxidant injury. Am J Physiol. 1997(4 Pt 1):856-65.

Pontes H, de Aquino Xavier F, TS DS, Fonseca F, Paiva H, Pontes F, et al. Metallothionein and p-Akt proteins in oral dysplasia and in oral squamous cell carcinoma: an immunohistochemical study. J Oral Pathol Med. 2009;38(8):644-50.

Posewitz M, Wilcox D. Properties of the Sp1 zinc finger 3 peptide: coordination chemistry, redox reactions, and metal binding competition with metallothionein. Chem Res Toxicol. 1995;8(8):1020-8.

Quaife CJ, Findley SD, Erickson JC, Froelick GJ, Kelly EJ, Zambrowicz BP, et al. Induction of a new metallothionein isoform (MT-IV) occurs during differentiation of stratified squamous epithelia. Biochemistry. 1994;33(23):7250-9.

Rahima B, Shingaki S, Nagata M, Saito C. Prognostic significance of perineural invasion in oral and oropharyngeal carcinoma. Oral Surg Oral Med Oral Pathol Oral Radiol Endod. 2004;97(4):423-31.

Rainwater $\mathrm{R}$. Role of cysteine residues in regulation of p53 function. Mol Cell Biol. 1995;15:3892-903.

Ren J, Privratsky J, Yang X, Dong F, Carlson E. Metallothionein alleviates glutathione depletion-induced oxidative cardiomyopathy in murine hearts. Crit Care Med. 2008;36(7):2106-16.

Ribeiro KC, Kowalski LP, Latorre MR. Impact of comorbidity, symptoms, and patients' characteristics on the prognosis of oral carcinomas. Arch Otolaryngol Head Neck Surg. 2000;126(9):1079-85.

Richards P. Recent Developments in Trace Element Metabolism an Function: I Role of Metallothionein in Copper and Zinc Metabolism1. Proteins. 1989;2:1062-70. 
Richards RI, Heguy A, Karin M. Structural and functional analysis of the human metallothionein-IA gene: differential induction by metal ions and glucocorticoids. Cell. 1984;37(1):263-72.

Rigby KE, Stillman MJ. Structural studies of metal-free metallothionein. Biochem. Biophys Res Commun. 2004;325(4):1271-8.

Rodini CO, Xavier FCA, Paiva KBS, De Souza Setúbal Destro MF, Moyses RA, Michaluarte $P$, et al. Homeobox gene expression profile indicates HOXA5 as a candidate prognostic marker in oral squamous cell carcinoma. Int $\mathrm{J}$ Oncol. 2012;40(4):1180-8.

Romero-Isart N, Vasák M. Advances in the structure and chemistry of metallothioneins. J Inorg Biochem. 2002;88(3-4):388-96.

Rusthoven K, Ballonoff A, Raben D, Chen C. Poor prognosis in patients with stage I and II oral tongue squamous cell carcinoma. Cancer. 2008;112(2):345-51. Saber R, Pişkin E. Investigation of complexation of immobilized metallothionein with $\mathrm{Zn}(\mathrm{II})$ and $\mathrm{Cd}(\mathrm{II})$ ions using piezoelectric crystals. Biosens Bioelectron. 2003;18(8):1039-46.

Sadhu C, Gedamu L. Regulation of Human Metallothionein ( MT ) Genes. J Biol Chem. 1988;263(6):2679-84.

Saga Y, Hashimoto H, Yachiku S, Tokumitsu M, Kaneko S. Immunohistochemical expression of metallothionein in human bladder cancer : correlation with histopathological parameters and patient survival. Cancer. 2002;168:2227-31.

Saika T, Tsushima T, Ochi J, Akebi N, Nasu Y, Matsumura Y, et al. Over-expression of metallothionein and drug-resistance in bladder cancer. Int J Urol. 1994;1(2):135-9.

Santos Almeida A, Oliveira DT, Pereira MC, Faustino SES, Nonogaki S, Carvalho $\mathrm{AL}$, et al. Podoplanin and VEGF-C immunoexpression in oral squamous cell carcinomas: prognostic significance. Anticancer Res. 2013;33(9):3969-76.

Sato M, Bremmer I. Oxygen free radicals and metallothionein. Free Radic. Biol. Med. 1993;14:325-37.

Sato M, Konkoh M. Recent studies on metallothionein: protection against toxicity of heavy metals and oxygen free radicals. Tohoku J Exp Med. 2002;196(1):9-22. 
Schlake T, Boehm T. Expression domains in the skin of genes affected by the nude mutation and identified by gene expression profiling. Mech Dev. 2001;109(2):419-22.

Schliephake H. Prognostic relevance of molecular markers of oral cancer-a review. Int J Oral Maxillofac Surg. 2003;32(3):233-45.

Schmid KW, Ellis I, Gee J, Darke B, Lees W, Kay J, et al. Presence and possible significance of immunocytochemically demonstrable metallothionein over-expression in primary invasive ductal carcinoma of the breast. Virchows Arch A Pathol Anat Histopathol. 1993;422(2):153-9.

Schmid KW, Greef M, Hittmair A, Totsch M, Ofner D, Dockhorn-Dworniczak B, et al. Metallothionein Expression in Normal, Hyperplastic, and Neoplastic Thyroid Follicular and Parafollicular C Cells Using Monoclonal Antimetallothionein Antibody E9. Endocr. Pathol. 2008;5(2):114-22.

Scully C, Field JK, Tanzawa H. Genetic aberrations in oral or head and neck squamous cell carcinoma (SCCHN): 1. Carcinogen metabolism, DNA repair and cell cycle control. Oral Oncol. 2000;36(3):256-63.

Sens MA, Somji S, Lamm DL, Garrett SH, Slovinsky F, Todd JH, Sens DA. Metallothionein isoform 3 as a potential biomarker for human bladder cancer. Environ Health Perspect. 2000;108(5):413-8.

Sens MA, Somji S, Garrett SH, Beall CL, Sens DA. Metallothionein Isoform 3 Overexpression Is Associated with Breast Cancers Having a Poor Prognosis. Environ. Heal. 2001;159(1):21-6.

Seve, M.; Chimienti, F.; Devergnas, S; Favier, A. In silico identification and expression of SLC30 family genes: Na expressed sequence tag data mining strategy for the characterization of zinc transporters tissue expression. BMC Genomics, London, v. 5, p. 32, 2004.

Sharkawy S, Farrag A. Mean nuclear area and metallothionein expression in ductal breast tumors: correlation with estrogen receptor status. App Immunohistochem Mol Morphol. 2008;16(2):108-12. 
Shimoda R, Achanzar WE, Qu W, Nagamine T, Takagi H, Mori M, et al. Metallothionein is a potential negative regulator of apoptosis. Toxicol Sci. 2003;73(2):294-300.

Shintani S, Li C, Ishikawa T, Mihara M, Nakashiro K, Hamakawa H. Expression of vascular endothelial growth factor A, B, C, and D in oral squamous cell carcinoma. Oral Oncol. 2004;40(1):13-20.

Shiraki M, Odajima T, Ikeda T, Sasaki A, Satoh M, Yamaguchi A, et al. Combined expression of p53, cyclin D1 and epidermal growth factor receptor improves estimation of prognosis in curatively resected oral cancer. Mod Pathol. 2005;18(11):1482-9.

Siegel R, Naishadham D, Jemal A. Cancer statistics, 2013. CA. Cancer J Clin. 2013;63(1):11-30.

Simpkins C, Balderman S, Mensah E, D P. Mitochondrial Oxygen Consumption Is Synergistically Inhibited by Metallothionein and Calcium. I Surg Res 1998;80(1):16 21.

Slaughter DP, Southwick HW, Smejkal W. Field cancerization in oral stratified squamous epithelium; clinical implications of multicentric origin. Cancer. 1953;6(5):963-8.

Somji S, Garrett SH, Zhou XD, Zheng Y, Sens DA, Sens MA. Absence of Metallothionein 3 Expression in Breast Cancer is a Rare, But Favorable Marker of Outcome that is Under Epigenetic Control. Toxicol. Environ. Chem. 2010;92(9):1673-95.

Somji S, Sens MA, Lamm DL, Garrett SH, Sens DA. Metallothionein isoform 1 and 2 gene expression in the human bladder: evidence for upregulation of MT-1X mRNA in bladder cancer. Cancer Detect Prev. $2001 ; 25(1): 62-75$.

Sousa SF, Gleber-Netto FO, de Oliveira-Neto HH, Batista AC, Nogueira Guimarães Abreu MH, de Aguiar MCF. Lymphangiogenesis and podoplanin expression in oral squamous cell carcinoma and the associated lymph nodes. Appl Immunohistochem Mol Morphol. 2012;20(6):588-94.

Su Y, Xia Y, Yang H, He J, Wu Q, Zheng Q, et al. Changes of superoxide dismutase (SOD) and metallothionien (MT) before, during, and after radiotherapy for nasopharyngeal carcinoma and their significance. Ai Zheng. 2003;22(6):629-33. 
Summers KL, Mahrok AK, Dryden MDM, Stillman MJ. Structural properties of metalfree apometallothioneins. Biochem Biophys Res Commun Elsevier Inc. 2012;425(2):485-92.

Sunardhi-Widyaputra S, van Den Oord J, Van Houdt K, De Ley M, Van Damme B. Identification of metallothionein and parathyroid hormone-related peptide (PTHrp)positive cells in salivary gland tumo. Patholl Res Pr. 1995;191(11):1092-8.

Sundelin K, Jadner M, Norberg-Spaak L. Metallothionein and Fas (CD95) are expressed in squamous cell carcinoma of the tongue. Eur J Cancer. 1997 b;33(11):1860-4.

Surowiak P, Materna V, Kaplenko I, Spaczyński M, Dietel M, Lage H, et al. Augmented expression of metallothionein and glutathione S-transferase pi as unfavourable prognostic factors in cisplatin-treated ovarian cancer patients. Virchows Arch. 2005;447(3):626-33.

Süslü N, Hoşal AŞ, Aslan T, Sözeri B, Dolgun A. Carcinoma of the oral tongue: a case series analysis of prognostic factors and surgical outcomes. J Oral Maxillofac Surg. 2013;71(7):1283-90.

Suzuki K, Koizumi S. Individual metal responsive elements of the human metallothionein-IIA gene independently mediate responses to various heavy metal signals. Ind Health. 2000;38(1):87-90.

Suzuki T, Umeyama T, Ohma C, Yamanaka H, Suzuki K, Nakajima K, et al. Immunohistochemical study of metallothionein in normal and benign prostatic hyperplasia of human prostate. Prostate. 1991;19:35-42.

Szelachowska J, Dziegiel P, Jelen-Krzeszewska J, Jelen M, Tarkowski R, Apytkowska B, et al. Correlation of metallothionein expression with clinical progression of cancer in the oral cavity. Anticancer Res. 2009;29(2):589-95.

Szelachowska J, Dziegiel P, Jelen-Krzeszewska J, Jelen M, Tarkowski R, Wlodarska I, et al. Prognostic significance of nuclear and cytoplasmic expression of metallothioneins as related to proliferative activity in squamous cell carcinomas of oral cavity. Histol Histopathol. 2008;23(7):843-51. 
Tai S-K, Tan OJ-K, Chow VT-K, Jin R, Jones JL, Tan P-H, et al. Differential expression of metallothionein 1 and 2 isoforms in breast cancer lines with different invasive potential: identification of a novel nonsilent metallothionein-1 $\mathrm{H}$ mutant variant. Am J Pathol. 2003;163(5):2009-19.

Takes RP, Rinaldo A, Silver CE, Piccirillo JF, Haigentz M, Suárez C, et al. Future of the TNM classification and staging system in head and neck cancer. Head Neck. 2010;32(12):1693-711.

Tan OJ-K, Bay B-H, Chow VT-K. Differential expression of metallothionein isoforms in nasopharyngeal cancer and inhibition of cell growth by antisense down-regulation of metallothionein-2A. Oncol Rep. 2005;13(1):127-31.

Tao X, Zheng J, Xu A, Chen X, Zhang S. Downregulated expression of metallothionein and its clinicopathological significance in hepatocellular carcinoma. Hepatol Res. 2007;10(37):820-7.

Tekur S, Ho S. Ribozyme-mediated downregulation of human metallothionein II(a) induces apoptosis in human prostate and ovarian cancer cell lines. Mol Carcinog. 2002;33:44-5.

Theocharis S, Margeli A, Klijanienko J, Kouraklis G. Metallothionein expression in human neoplasia. Histopathology. 2004;45(2):103-18.

Thirumoorthy N, Manisenthil Kumar I, Sundar AS, Panayappan L, Chatterjee M. Metallothionein: an overview. World J Gastroenterol. 2007;13(7):993-6.

Thomson PJ, Goodson ML, Booth C, Cragg N, Hamadah O. Cyclin A activity predicts clinical outcome in oral precancer and cancer. Int J Oral Maxillofac Surg. 2006;35(11):1041-6.

Thornalley PJ, Vasák M. Possible role for metallothionein in protection against radiation-induced oxidative stress. Kinetics and mechanism of its reaction with superoxide and hydroxyl radicals. Biochim Biophys Acta. 1985;827(1):36-44.

Tian Z-Q, Wang X-L, Wu W. [Expression of metallothionein-3 in esophageal cancer and its correlations to expression of metallothionein-1 and -2]. Ai Zheng.

2008;27(2):160-4. 
Tian ZQ, Xu YZ, Zhang YF, Ma GF, He M, Wang G-Y. Effects of metallothionein-3 and metallothionein-1E gene transfection on proliferation, cell cycle, and apoptosis of esophageal cancer cells. Genet Mol Res. 2013;12(4):4595-603.

Tom M, Chen N, Segev M, Herut B, Rinkevich B. Quantifying fish metallothionein transcript by real time PCR for its utilization as an environmental biomarker. Evaluation. 2003;1-6.

Tuccari G, Giuffrè F, Arena F, Barresi G. Immunohistochemical detection of metallothionein in carcinomatous and normal human gastric mucosa. Histol Histopathol. 2000;15(4):1035-41.

Valko M, Rhodes C, Moncol J, Izakovic M, Mazur M. Free radicals, metals and antioxidants in oxidative stress-induced cancer. Chem Biol Interact. 2006;160(1):140.

Vallee BL. The function of metallotihonein. Science (80). 1995;27(1):23-33.

Vasconcelos MH, Tam S, Hesketh JE, Reid M, Beattie JH, Appl JHT. Metal- and Tissue-Dependent Relationship between Metallothionein mRNA and Protein. Toxicol Appl Pharmacol. 2002;97:91-7.

Vicente JC, Fresno MF, Villalain L, Vega JA, Hernández Vallejo G. Expression and clinical significance of matrix metalloproteinase-2 and matrix metalloproteinase-9 in oral squamous cell carcinoma. Oral Oncol. 2005;41(3):283-93.

Warburton G, Nikitakis NG, Roberson P, Marinos NJ, Wu T, Sauk JJ, et al. Histopathological and lymphangiogenic parameters in relation to lymph node metastasis in early stage oral squamous cell carcinoma. J. Oral Maxillofac. Surg. 2007;65(3):475-84.

Watters AL, Epstein JB, Agulnik M. Oral complications of targeted cancer therapies: a narrative literature review. Oral Oncol. 2011;47(6):441-8.

Wei H, Desouki MM, Lin S, Xiao D, Franklin RB, Feng P. No TitleDifferential expression of metallothioneins (MTs) 1,2, and 3 in response to zinc treatment in human prostate normal and malignant cells and tissues. Mol Cancer. 2008;7(7):1-27. 
Werynska B, Pula B, Muszczynska-Bernhard B, Gomulkiewicz A, Jethon A, Podhorska-Okolow M, et al. Expression of metallothionein-III in patients with nonsmall cell lung cancer. Anticancer Res. 2013a;33(3):965-74.

Werynska B, Pula B, Muszczynska-Bernhard B, Gomulkiewicz A, Piotrowska A, Prus $\mathrm{R}$, et al. Metallothionein $1 \mathrm{~F}$ and $2 \mathrm{~A}$ overexpression predicts poor outcome of nonsmall cell lung cancer patients. Exp. Mol. Pathol. 2013b;94(1):301-8.

Willner $\mathrm{H}$, Vasák M, Kägi JH. Cadmium-thiolate clusters in metallothionein: spectrophotometric and spectropolarimetric features. Biochemistry. 1987;26(19):6287-92.

Winge D, Miklossy K. Domain nature of metallothionein. J Biol Chem. 1982;257(7):3471-6.

Woolgar JA, Rogers SN, Lowe D, Brown JS, Vaughan ED. Cervical lymph node metastasis in oral cancer: the importance of even microscopic extracapsular spread. Oral Oncol. 2003;39(2):130-7.

Yagle MK, Palmiter RD. Coordinate regulation of mouse metallothionein I and II genes by heavy metals and glucocorticoids. Mol Cell Biol. 1985;5(2):291-4.

Yamasaki Y, Smith C, Weisz D, van Huizen I, Xuan J, Moussa M, et al. Metallothionein expression as prognostic factor for transitional cell carcinoma of bladder. Urology. 2006;67(3):530-5.

Yang X, Doser T, Fang C, Nunn J, Janardhanan R, Zhu M, et al. Metallothionein prolongs survival and antagonizes senescence-associated cardiomyocyte diastolic dysfunction: role of oxidative stress. FASEB J. 2006;20(7):1024-6.

Yang Y, Maret W, Vallee BL. Differential fluorescence labeling of cysteinyl clusters uncovers high tissue levels of thionein. Proc Natl Acad Sci USA. 2001;98(10):55569.

Yap X, Tan H, Huang J, Lay Y, Yip GW, Tan P-H, et al. Over-expression of metallothionein predicts chemoresistance in breast cancer. J Pathol. 2009;217(4):563-70. 
Yeole BB, Sankaranarayanan R, Sunny M Sc L, Swaminathan R, Parkin DM. Survival from head and neck cancer in Mumbai (Bombay), India. Cancer. 2000;89(2):437-44.

Yuan JS, Reed A, Chen F, Stewart CN. Statistical analysis of real-time PCR data. BMC Bioinformatics. 2006;7:85.

Zavras a I, Yoon a J, Chen MK, Lin CW, Yang SF. Metallothionein-1 genotypes in the risk of oral squamous cell carcinoma. Ann Surg Oncol. 2011;18(5):1478-83.

Zeng J, Heuchel R, Schaffner W, Kagi J. Thionein (apometallothionein) can modulate DNA binding and transcription activation by zinc finger containing factor Sp1. FEBS Lett. 1991a;279(2):310-2.

Zeng J, Vallee BL, Kag J. Zinc transfer from transcription factor IIIA fingers to thionein clusters. Proc Natl Acad Sci USA. 1991b;88:9984-8.

Zhang R, Zhang $\mathrm{H}$, Wei $\mathrm{H}$, Luo X. Expression of metallothionein in invasive ductal breast cancer in relation to prognosis. J Envinon Pathol Toxicol Oncol. 2000;19(1):95-7.

Zhang X, Jin LI, Sakamoto H, Takenaka I. Immunohistochemical Localization Of Metallothionein In Human Prostate Cancer. 1996;1679-81.

Zhao D, Wang S-H, Feng Y, Hua C-G, Zhao J, Tang X-F. Intratumoral c-Met expression is associated with vascular endothelial growth factor $C$ expression, lymphangiogenesis, and lymph node metastasis in oral squamous cell carcinoma: implications for use as a prognostic marker. Hum Pathol. 2011;42(10):1514-23.

Zhu J, Meeusen J, Krezoski S, Petering DH. Reactivity of Zn-, Cd-, and apometallothionein with nitric oxide compounds: in vitro and cellular comparison. Chem Res Toxicol. 2010;23(2):422-31. 
APÊNDICE A - Relação dos valores de p obtidos após testes estatísticos comparando a mucosa oral com os dados clínico-patológicos dos pacientes

Tabela. Comparações por grupos considerando dados clínico-patológicos e a expressão dos genes das metalotioneínas em mucosa oral não-neoplásica correspondente (MOC) aos casos de carcinoma epidermoide bucal (CEB).

\begin{tabular}{|c|c|c|c|c|c|c|c|c|}
\hline \multirow{2}{*}{$\begin{array}{l}\text { Parâmetros } \\
\text { Clínico- } \\
\text { patológicos }\end{array}$} & \multicolumn{8}{|c|}{ Genes das metalotioneínas } \\
\hline & MT1A & MT1E & MT1F & MT1G & MT1X & MT2A & MT3 & MT4 \\
\hline $\begin{array}{l}\text { Idade } \\
(35-60 \text { ou } \\
>60)\end{array}$ & 0,16 & 0,05 & 0,85 & 0,51 & 0,93 & 0,23 & 0,85 & 0,62 \\
\hline Sexo & 0,59 & 0,09 & 0,89 & 0,3547 & 0,72 & 0,12 & 0,56 & 0,62 \\
\hline Tabagismo & 0,81 & 0,81 & 0,75 & 0,43 & 0,28 & 0,16 & 0,65 & 0,29 \\
\hline Etilismo & 0,35 & 0,42 & 0,80 & 0,52 & 0,68 & 0,26 & 0,39 & 0,10 \\
\hline Localização & 0,85 & 0,22 & 0,51 & 0,77 & 0,93 & 0,66 & 0,32 & 0,66 \\
\hline
\end{tabular}

Diferenças significativas foram consideradas quando $p<0,05$.

OBS: Diferença aproximando de significância estatística apenas com relação à expressão de MT1E de acordo com a idade dos pacientes. Em pacientes com mais de 60 anos, há menor mediana de expressão $(0,0208$; variando de 0,0012 a 0,1260$)$ do que em pacientes com menos de 60 anos (0,0415; variando de 0,0035 a 0,4314). 
ANEXO A - Parecer do comitê de ética em pesquisa do INCA-RJ

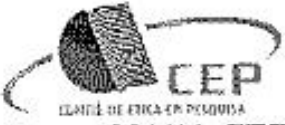

Memo 231/11-CEP-INCA

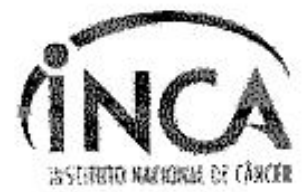

Rio de Janeiro, $1^{\circ}$ de agosto de 2011.

$\mathrm{A}(\mathrm{o})$ : Dr. Fernando Luiz Dias

Pesquisador(a) Principal

Registro CEP $n^{\circ}$ 48/11 (Este $n^{\circ}$. deve ser citado nas correspondências referentes a este estudo) CAAE - 0644.0.000.007.11

Título do Estudo: Estudo da expressão gênica das isoformas de Metalotioneina e sua relação com prognóstico em carcinomas de cabeça e pescoço

Prezado(a) Pesquisador(a),

Informo que o Comitê de Ética em Pesquisa do Instituto Nacional de Câncer aprovou após re-análise o estudo intitulado: Estudo da expressão gênica das isoformas de Metalotioncína e sua relação com prognóstico em carcinomas de cabeça c pescoço (protocolo versão 2), bem como o seu TCLE versāo 2, em 10 de julho de 2011.

Ressalto o(a) pesquisador(a) responsável deverá apresentar relatórios semestrais a respeito do seu estudo.

Atenciosamente,

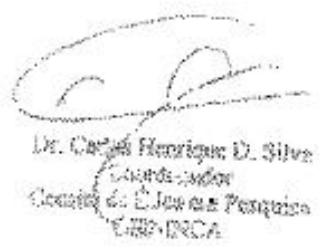

C/c-Dr. Sylvio Lemos - Diretor do HCI 
ANEXO B - Parecer do consubstanciado do comitê de ética em pesquisa da Faculdade de Odontologia da Universidade de São Paulo

Plataforma Brasil - Ministério da Saúde

Faculdade de Odontologia da Universidade de Săo Paulo

PROJETO DE PESQUISA

Titulo: Esludo da expressăo gênica das isoformas de Melalotionelna e sua relaçăo com prognóstico em carcinomas epidermoides bucais

Area Temática:

Pesquisador:Suzana Cantanhede Orsini Machado de Sousa Versāo: 1 Instituiçăo:

Faculdade de Odontologia da Universidade de

CAAE: 04055712.4 .0000 .0075

Sāo Paulo

\section{PARECER CONSUBSTANCIADO DO CEP}

Número do Parecer: 47833

Data da Relatoria: $\quad 29 / 06 / 2012$

Apresentaçāo do Projeto:

Estudo longitudinal, retrospectivo, com a utilizaçāo de uma amostra de conveniência, representada por amostras tumorais congeladas de carcinoma epidermoide envolvendo língua e línguafassoalho bucal. disponiveis no Banco Nacional de Tumores do INCA (BNT-INCA) dentre os períodos de 2007 a 2009 . A variável de interesse será a expressäo genética da Metalotioneína, considerando suas variáveis de transcriçäo MT-1A, $-1 B,-1 E,-1 F$

$-1 G,-1 H,-1 M,-1 X,-2 A$. A avaliaçăo será por meio da técnica de qRT-PCR utilizando os kíts de extraçăo e de transcriçāo reverșa da Qiagen, e posteriormente os primers desenhados pela Applied.

\section{Objetivo da Pesquisa:}

O presente trabalho tem como objelivo avaliar p padra a de transcriçăo da MT-1, MT-2, MT-3 e MT-4 nas amostras de CEC armazenadas no banco de tumores do Instituto Nacional de Cáncer (INCA) dentre o periodo de 2007 a 2009. Serâo considerandos como fatores em estudo os aspectos clinicopatológicos (topografia das lesōes e grau histológico), os fatores considerados marcadores de prognóstico (tamanho da lesāo, recidiva, metástase $\theta$ obito), $\theta$ a quantificaço de RNAm das isoformas da MT.

\section{Avaliaçâo dos Riscos e Benefícios:}

Nāo existem riscos adicionais ao paciente, visto que os tumores que serāo analisados já foram diagnosticados e a utilizaçăo dos mesmos nåa compromelem o andamento e acompanhamento dos tratamentos necessários. Os dados clínicopatológicos serāo utilizados em planilhas sem identificaçāo do paciente, que receberá um código, tendo identificaçăo preservada, exclusivamente em forma de esludo epidemiologico.

\section{Comentários e Consideraçöes sobre a Pesquisa:}

A pesquisá năo fere nenhum preceito ético

\section{Consideraçōes sobre os Termos de apresentação obrigatória:}

Os termos apresentados estăo corretos e nada falta

\section{Recomendaçöes:}

Tendo em vista a legislaçăo vigente, devem ser encaminhados ao CEP-FOUSP relatórios parciais anuais referentes ao andamento da pesquisa e relatório final ao término do trabalho. Qualquer modificaçāo do projeto original deve ser apresentada a este CEP, de forma objetiva e com justificativas, para nova apreciaç. 
Conclusōes ou Pendências e Lista de Inadequaçōes:

Nāo hà pendencias no relatório.

Segundo Carta N ${ }^{\circ}$ 0212fCONEPICNS, de 21 de outubro de 2010, a INSTITUIÇĀO CO-PARTICIPANTE deve emitir declaraçāo que concordar com o parecer ético emitido pelo CEP da instituiçāo proponente,no caso o CEP-FOUSP, conhecer e cumprit as Resoluçes Éticas Brasileiras, em especial a Resoluçăo CNS $196 / 96$. Declarar que está ciente de suas co-responsabilidades como instituiçāo co-participante do presente projeto de pesquisa, e de seu compromisso no resguardo da segurança e bem-estar dos sujeitos de pesquisa nela recrutados, dispondo de infra-estrutura necessária para a garantia de tal segurança e bem estar.

\section{Situação do Parecer:}

Aprovado

Necessita Apreciaçåo da CONEP

Nazo

Na data de emissão desse parecer estavam pendentes os pareceres de algumas coparticipantes. As mesmas deverăo ser apresentadas antes do início do projeto.

SAO PALLO, 29 de Junho de 2012

Assinado por.

Marcia Turolla Wanderley 